\title{
France: Financial System Stability Assessment, including Reports on the Observance of Standards and Codes on the following topics: Monetary and Financial Policy Transparency, Banking Supervision, Securities Regulation, Insurance Regulation, Payment Systems, Securities Settlement, and Anti-Money Laundering and Combating the Financing of Terrorism
}

This Financial System Stability Assessment on France was prepared by a staff team of the International Monetary Fund and the World Bank as background documentation for the periodic consultation with the member country. It is based on the information available at the time it was completed on September 21, 2004. The views expressed in this document are those of the staff team and do not necessarily reflect the views of the government of France or the Executive Board of the IMF.

The policy of publication of staff reports and other documents by the IMF allows for the deletion of market-sensitive information.

To assist the IMF in evaluating the publication policy, reader comments are invited and may be sent by e-mail to publicationpolicy@imf.org.

Copies of this report are available to the public from

International Monetary Fund • Publication Services

700 19th Street, N.W. • Washington, D.C. 20431

Telephone: (202) 6237430 • Telefax: (202) 6237201

E-mail: publications@imf.org • Internet: http://www.imf.org

Price: $\$ 15.00$ a copy

\section{International Monetary Fund} Washington, D.C. 



\title{
INTERNATIONAL MONETARY FUND
}

\section{FRANCE}

\section{Financial System Stability Assessment}

\section{Prepared by the Monetary and Financial Systems and European Departments}

\author{
Approved by Stefan Ingves and Michael Deppler
}

September 21, 2004

This report is based primarily on work undertaken during two visits to France during February and May 2004, as part of the Financial Sector Assessment Program (FSAP). The FSAP findings were discussed with the authorities during the Article IV consultation mission in July 2004.

The FSAP team comprised Tomás J.T. Baliño (Head), Piero Ugolini, Wim Fonteyne, Daniel Hardy, Richard Lalonde, Andrea Maechler, Rodolfo Maino, Sandra Marcelino, Jan Willem van der Vossen, and Jan Woltjer (all MFD); Céline Allard (EUR); Toni Gravelle (ICM); Nadim Kyriakos-Saad (LEG); Andrea Corcoran (U.S. Commodities Futures Trading Commission); Ludovic D'Hoore (Belgian Cellule de Traitement des Informations Financières); Philippe Fleury (Swiss Autorité de contrôle en matière de lutte contre le blanchiment d'argent); Daniel Heller (Swiss National Bank); and Helmut Müller (formerly German Federal Insurance Supervision Agency). The FSAP team received excellent cooperation from the authorities and market participants. The main findings of the FSAP are:

- The financial sector is strong and well supervised. On present analysis, no weaknesses that could cause systemic risks were identified.

- Concentration in banking may have reached a point where further domestic consolidation could raise competition and long-term stability issues.

- The supervisory system of the financial sector is segmented and specialized and requires strong coordination mechanisms.

- Progressive integration across financial sectors and international borders will present challenges, with implications for stability and competition. Efficiency and responsiveness to policy signals could be enhanced by rationalizing and modernizing financial sector policies (such as the administered savings schemes).

- A high degree of observance of international standards for financial policies has been achieved. The authorities are working to fill remaining gaps, for example, in the regulation of reinsurance, the clearing and settlement system, and AML/CFT provisions outside the banking system.

The main authors of this FSSA are Tomás J.T. Baliño, Piero Ugolini, and Daniel Hardy, with contributions from the rest of the FSAP team.

FSAPs are designed to assess the stability of the financial system as a whole and not that of individual institutions. They have been developed to help countries identify and remedy weaknesses in their financial sector structure, thereby enhancing their resilience to macroeconomic shocks and cross-border contagion. FSAPs do not cover risks that are specific to individual institutions such as asset quality, operational or legal risks, or fraud. 


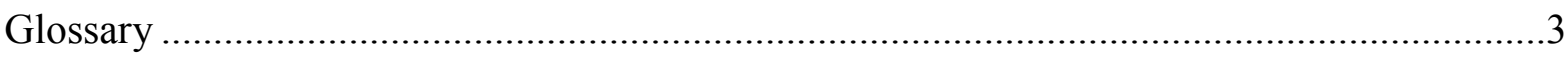

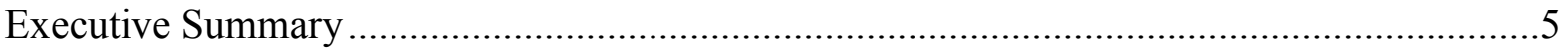

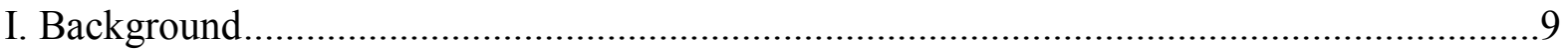

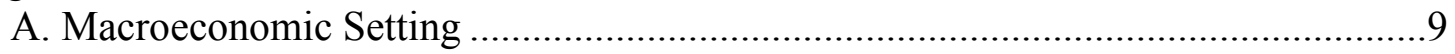

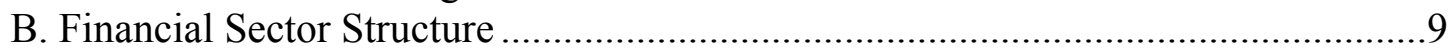

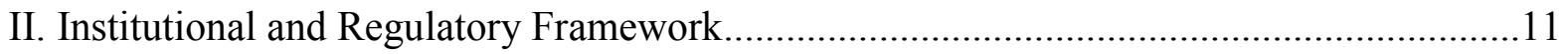

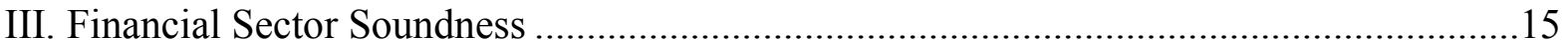

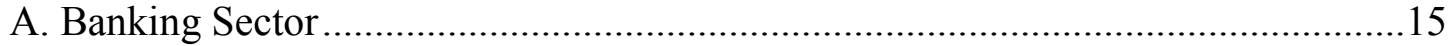

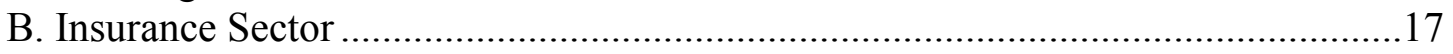

IV. Structural Issues and Financial Sector Efficiency ....................................................19

Figures

1. Corporate and Household Debts, 1993-2003 …........................................................ 10

2. Financial Sector Structure as of December 2003 ....................................................... 10

Boxes

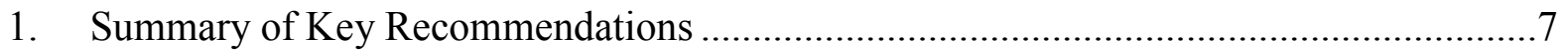

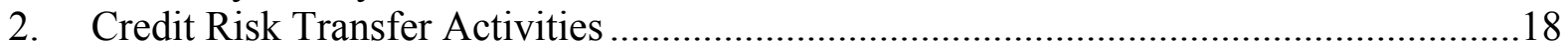

3. Restructuring La Poste's Activities .........................................................................22

Annex

Observance of Financial Sector Standards and Codes - Summary Assessments..................23

Appendices

I. Structure and Evolution of the French Financial System .......................................91

II. Stress Testing Procedures and Assumptions................................................................ 97

III. Effects of Savings Schemes and Other Government Intervention..............................100

Statistical Tables

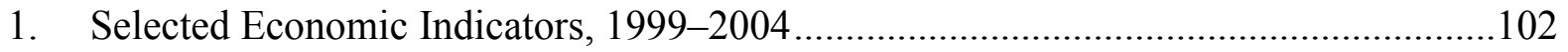

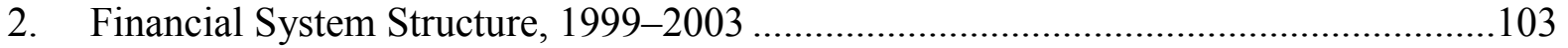

3. Banking Sector: Financial Soundness Indicators, 1999-2003 ….............................104

4. Life Insurance: Financial Soundness Indicators, 1998-2002 ..................................105

5. Non-Life Insurance: Financial Soundness Indicators, 1998-2002 .............................106

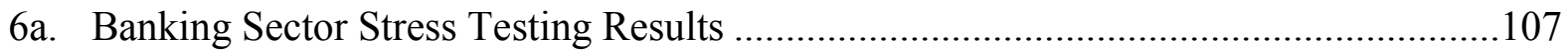

6b. Insurance Sector Stress Testing Results .................................................................109 


\section{GLOSSARY}

\begin{tabular}{|c|c|}
\hline AMF & Autorité des Marchés Financiers \\
\hline AML & Anti-Money Laundering \\
\hline APE & Agence des Participations de l'État \\
\hline ATM & Automated Teller Machines \\
\hline ATS & Automated Trading Systems \\
\hline $\mathrm{BCP}$ & Basel Committee's Core Principles for Effective Banking Supervision \\
\hline $\mathrm{BdF}$ & Banque de France \\
\hline BTANs & Bons du à faux fixe et à intérêt annuel \\
\hline BTFs & Bons du Trésor à faux fixe et à intérêts prècomptés \\
\hline CAR & Capital Adequacy Ratio \\
\hline $\mathrm{CB}$ & Commission Bancaire \\
\hline CCA & Commission de Contrôle des Assurances \\
\hline CCAMIP & Commission de Contrôle des Assurances, Mutuelles et Institutions de Prévoyance \\
\hline CCMIP & Commission de Contrôle des Mutuelles et des Institutions de Prévoyance \\
\hline $\mathrm{CDC}$ & Caisse des Dépôts et Consignations \\
\hline CDD & Customer Due Diligence \\
\hline CDGF & Conseil de Discipline de la Gestion Financière \\
\hline CEA & Comité des Entreprises d'Assurance \\
\hline CECEI & Comité des Établissements de Crédit et des Entreprises d'Investissement \\
\hline CEL & Compte Épargne Logement \\
\hline CESR & Committee of European Securities Regulators \\
\hline CFT & Combating the Financing of Terrorism \\
\hline CIRCE & Charte Interbancaire Régissant les Conditions d'Échange \\
\hline CIS & Collective Investment Schemes \\
\hline $\mathrm{CMF}$ & Conseil des Marchés Financiers \\
\hline CMT & Conseil des Marchés à Terme \\
\hline $\mathrm{COB}$ & Commission des Opérations de Bourse \\
\hline CPSS & Committee on Payment and Settlement Systems \\
\hline CPSIPS & CPSS's Core Principles for Systemically Important Payment Systems \\
\hline CRBF & Comité de la Réglementation Bancaire et Financière \\
\hline CRI & Centrale des Réglements Interbancaires \\
\hline CSD & Central Security Depository \\
\hline DIF & Décisions et Informations Financières \\
\hline DOM-TOM & Départements et Territoires d'Outre-Mer (Overseas departments and territories) \\
\hline ECB & European Central Bank \\
\hline EEA & European Economic Area \\
\hline EMU & European Monetary Union \\
\hline EU & European Union \\
\hline FATF & Financial Action Task Force \\
\hline FGD & Fond de Garantie des Dépôts \\
\hline FIU & Financial Intelligence Unit \\
\hline FSAP & Financial Sector Assessment Program \\
\hline FSSA & Financial System Stability Assessment \\
\hline FT & Financing of Terrorism \\
\hline GECO & Gestion Collective \\
\hline GSIT & Groupement pour un Système Interbancaire de Télécompensation \\
\hline IAIS & International Association of Insurance Supervisors \\
\hline IAS & International Accounting Standards \\
\hline
\end{tabular}


IASB International Accounting Standards Board

ICP Insurance Core Principles

IFRS International Financial Reporting Standards

IGF Inspection Générale des Finances

IOSCO International Organization of Securities Commissions

JORF Journal of the French Republic

LEP Livret d'Épargne Populaire

LIFFE London International Financial Futures Exchange

MATIF Marché à Terme International de France (French Financial Future Market)

MFP Monetary and Financial Policies

MINEFI Ministry of Economy, Finance, and Industry

ML Money Laundering

MONEP Marché des Options Négociables de Paris (Paris traded options)

MOU Memorandum of Understanding

NPL Nonperforming loans

OATs Obligations Assimilables du Trésor

OF Obligations Foncières

OPSR Objectives and Principles of Securities Regulation

OTC Over-the-Counter

PEA Plan d'Épargne en Actions

PEL Plan d'Épargne Logement

PERP Plan d'Épargne Retraite Populaire (Retirement plan)

PNS Paris Net Settlement system

POS Point of Sale

RGV Relit Grande Vitesse

ROA Return on assets

ROE Return on Equity

ROSC Report on Observance of Standards and Codes

RSSS CPSS/IOSCO Recommendation for Securities Settlement Systems

RTGS Real-Time Gross Settlement systems

SCP IOSCO's Core Principles of Securities Regulation

SCSS Securities Clearing and Settlement Systems

SEPA Single European Payments Area

SFSA Savings and Financial Securities Act

SIPS Systemically Important Payment Systems

SIT Système Interbancaire de Télécompensation (French automated clearing house for retail payments)

SRDs $\quad$ Service de réglement différé (Deferred settlement positions)

SSS Securities Settlement Systems

STR Suspicious Transaction Report

SWIFT Society for World-wide Interbank Financial Telecommunication

TARGET Trans-European Automated Real-time Gross settlement Express Transfer system

TBF Transferts Banque de France

TFT Trade For Trade gross settlement system for securities

TIP Titre Interbancaire de Paiement

TRACFIN Treatment of Information and Action Against Clandestine Financial Circuits

UCITS Undertakings for the Collective Investment of Transferable Securities

UN United Nations

UNSCR United Nations Security Council Special Resolution 


\section{EXECUTIVE SUMMARY}

France's financial sector is strong and well supervised. On present analysis, no weaknesses that could cause systemic risks were identified. The strength of the system is supported by the financial soundness indicators and the strong conformity to the supervisory and regulatory standards approved by the Basel Committee, IAIS, IOSCO, FATF, and CPSS. The degree of observance of the transparency code is high in all relevant areas.

The French banking system has been modernized and restructured over the past two decades. Consolidation among financial institutions has resulted in six large universal, vertically integrated banking groups having a strong position in the domestic market. Mutual groups have been a key driving force in the consolidation. The system has been almost entirely privatized and relieved of most of its public policy roles, although strong government influence (mainly through the administered savings schemes and tax provisions) remains. As in other industrialized countries, wholesale banking is more open to international competition than retail banking and the emphasis on "national champions" in banking may have limited the scope for cross-border cooperation and consolidation.

The banking sector is well capitalized. The reported level of NPLs was stable through the recent economic downturn. Bank profitability has improved markedly over the past decade and is in line with average euro area levels. Stress test results corroborated the sector's resilience.

Systemic vulnerabilities in the important insurance sector are well contained. The sector showed resilience to recent shocks (for example, the significant fall in equity prices, historically low interest rates, and natural catastrophes), and available sector soundness indicators and stress test results are satisfactory. Additional sources of stability include conservative investment portfolios, the success of the life sector in shifting investment risks to policyholders, and limited domestic provision of reinsurance.

Securities markets are large and sophisticated. Exchange-traded equities and derivatives markets have been restructured. The government debt market is large and the corporate debt market has been growing rapidly since the introduction of the euro.

Notwithstanding the strengths of the French financial sector, a number of issues-many of which are also found in other advanced countries-emerged from the FSAP and deserve the authorities' attention (the key recommendations are summarized in Box 1):

- Concentration in banking may have reached a point where further consolidation could intensify concerns over the scope for collusion and long-term stability where many banks could be considered "too big to fail."

- Banks' large and growing portfolios of fixed-rate residential housing loans could represent a longer-term risk in the event of large increases in funding costs and/or a 
significant fall in real estate prices. However, short-term vulnerabilities and household debt remain low.

- Some administered savings schemes and other policy measures give rise to costs and impede financial market innovation. These schemes are not well targeted to achieve intended social goals, and are not well aligned with current priorities, such as strengthening the pension system.

- The banking system's rapid accumulation of capital strengthens banks' resilience. This accumulation is harder to control for mutual banks, given their legal restrictions on remuneration of their members. And, for all banks, it could encourage expansion through expensive takeovers and risky new ventures.

- The supervisory system of the financial sector is composed of specialized segments. Recent steps to streamline the supervisory structure are welcome, but coordination mechanisms need to be adapted following the changes. Additional steps should be considered in the future as cross-sectoral financial groups become more prevalent.

- Government and industry representation in the supervisory process can give rise to interference and at least the appearance of conflicts of interest. The Ministry of Finance retains full responsibility for issuing prudential rules for banking, certain investment services providers, and insurance (although the relevant supervisory authorities are fully consulted). It also participates in the AMF body that hears sanction proceedings affecting security market participants. The presence of industry representatives raises other conflict issues.

- The insurance industry is facing a number of challenges over the medium term. Key challenges facing the industry include the possibility of a sharp and sustained increase in interest rates, and the adoption of new IFRS standards. As in other countries, regulation of the reinsurance sector is relatively weak. The authorities are working on preemptive measures, such as the refinement of risk-management practices and an EU-wide initiative to strengthen the regulatory framework for reinsurance.

- The consolidation of the French stock and futures markets with others in Europe has increased the importance of effective cooperation across national jurisdictions. Moreover, the authorities face the challenge of adjusting to and effectively implementing the significant regulatory overhaul that took place in late 2003.

- The infrastructure for clearing and settlement of payments and securities is generally sound and modern. However, there is some room for improvement in the clearing and settlement of retail payments and securities, where the multilateral 
netting systems lack fully adequate safeguards to ensure timely settlement in case of default.

- The overall legal and institutional framework for AML/CFT is comprehensive. France maintains a high level of compliance with the FATF 40+8 Recommendations, and has gone beyond the standard in a number of areas, such as sectoral coverage and reporting requirements for the import and export of monetary instruments. However, further improvements could be achieved in some areas, mainly: the implementation of UN Security Council Special Resolution on terrorism financing (an issue common to other EU countries); the overall quality of suspicious transactions reporting (STR); AML/CFT regulation, supervision and enforcement for sectors other than credit institutions and certain investment firms; and criteria for when financial institutions should exercise increased diligence.

\section{Box 1. Summary of Key Recommendations}

Banking issues

- Ongoing efforts to reform the government's influence over savings allocation through various schemes and fiscal incentives should be accelerated with the medium-term objective of their orderly phase-out. In the short term, the focus should be on reducing the distortions caused by the schemes and realigning them with current priorities, for example, by reducing the incentives to save for housing, which would make personal pension schemes more attractive. Other measures, required in their own right and also facilitated by the current low interest rate environment, could include eliminating the "ni-ni" rule (which prohibits the payment of interest on demand deposits and charging for checkbooks) and relaxing the limit on "usurious" lending rates.

- Given the current degree of concentration in the financial system, continued vigilance is needed to preserve a healthy level of competition. Ongoing efforts to improve disclosure and pricing transparency requirements for banking services will foster competition and should be continued. Separating La Poste's banking activities and subjecting them to standard prudential requirements is welcome. However, it must compete on a "level playing field" with other banks in terms of its tax status and costing its use of postal facilities. Consideration should be given to its eventual privatization. Competition at the retail level and the availability of financial services could further be enhanced by moving away from the notion of "national champions" and introducing a positive credit registry.

- Corporate governance and risk taking of banks need to be monitored carefully, particularly when they expand into unfamiliar activities. Potential pressure on banks to over-expand could be eased by reducing barriers to the return of profits to owners. It would also help to reduce legal impediments to changes in ownership structure and to encourage financial institutions to increase the share of their equity held in negotiable form.

- Improving creditor legal rights would facilitate the provision of credit. The ongoing reform of the corporate bankruptcy legislation should help clarify and limit the liability of creditors, while also facilitating the restructuring of troubled companies. In addition, banks should be allowed to write off nonperforming loans without jeopardizing their legal claim on the debtor. 
Insurance

\section{Box 1. Summary of Key Recommendations (Continued)}

- $\quad$ Regulations on corporate governance, internal controls, and risk management should be upgraded and improved. Adding supervisory staff may help speed up harmonization of the supervisory and regulatory framework across the industry. The Ministry of Finance should delegate to the supervisory agency the authority to issue regulations, as it is already the case in other supervisory agencies.

- The supervision of the reinsurance sector should be strengthened and France should anticipate the main elements of recent $E U$ initiatives in this area.

\section{Securities market}

- The effectiveness of the securities regulator could be strengthened by requiring (rather than just authorizing) cooperation across authorities and removing the government's presence from the sanctioning commission.

- $\quad$ Minimum standards of conduct for marketing collective investment schemes (mutual funds); the regulator's resources to inspect investment service providers, especially CIS depositories; and its powers to oversee audits of public companies should be enhanced. The timeliness of public disclosure of insider transactions should be strengthened.

\section{Payment and securities settlement systems}

- Measures should be taken to protect the financial system against potential disruptions that arise in the multilateral netting systems by implementing as soon as possible appropriate safeguards to comply with international standards.

- An analysis of concentration risk should be undertaken, given the prevalence of tiering in some systems. The analysis may suggest institutional changes to reduce tiering without loss of efficiency.

\section{$A M L / C F T$}

- The legal and regulatory framework should be strengthened to complete the implementation of UN Security Council Special Resolution 1373 on terrorist financing and to align the suspicious transaction reporting requirement with predicate offenses for money laundering.

- $\quad$ Further guidance should be provided to reporting entities, including those in the Overseas Departments and Territories, to improve the detection of suspicious transactions and the rate and quality of their reporting.

- Regulation and supervision of AML/CFT provisions for sectors other than credit institutions and certain investment firms should be strengthened, and corresponding resources of the relevant agencies increased. Enforcement efforts vis-à-vis unlicensed informal funds transfer businesses should be reviewed and monitored more closely. Provisions regarding increased diligence, and those regarding the application of AML/CFT requirements to branches and subsidiaries located abroad, should be enhanced. 


\section{BACKGROUND}

\section{A. Macroeconomic Setting ${ }^{1}$}

1. After a marked slowdown in economic activity in 2003 , the cyclical recovery is now well established, with domestic demand as key driver and external factors constituting downside risks. Inflation has only moderately picked up due to oil price developments and ex-post real interest rates have sunk to unusually low levels.

2. Despite slow growth up to mid-2003, the financial situation of the corporate sector has deteriorated only slightly since 2000 , and, except for a few large companies, corporate leverage is generally low. Likewise, household debt levels relative to incomes and assets are comparatively low (albeit rising), and savings rates are high (albeit decreasing) (Figure 1 and Table 1). However, low interest rates and rising prices may induce households to take out larger mortgage loans, which may impact on their future financial position. ${ }^{2}$ Equity prices remain below their 2000 highs, despite the recent recovery, but some investors enjoy offsetting gains on bonds. Commercial real estate prices have remained stable following the early-1990s boom-bust cycle.

\section{B. Financial Sector Structure}

3. The financial sector is large, sophisticated, and of international importance (Appendix I). The system has consolidated rapidly: it is now dominated by six vertically integrated universal banks and their nonbank subsidiaries. Four of the six are organized on a mutual basis, some of which, however, have created or acquired joint-stock affiliates. Two large financial institutions, La Poste and the CDC, remain in government ownership. The government continues to influence strongly the mobilization and allocation of savings through various means, including differentiated tax provisions, some controls on interest rates and fees, and the administration of several savings schemes. Besides banks, important financial sectors include insurance (especially life insurance, which serves as a vehicle for retirement savings), and the markets for equity and public debt (Figure 2).

\footnotetext{
${ }^{1}$ The accompanying Staff Report on the 2004 Article IV Consultations discusses macroeconomic developments in greater depth.

${ }^{2}$ Housing prices have been increasing at an annual rate of 10 percent since 1997 . However, in nominal terms they are not far above the peak reached in 1989.
} 
Figure 1. Corporate and Household Debts, 1993-2003

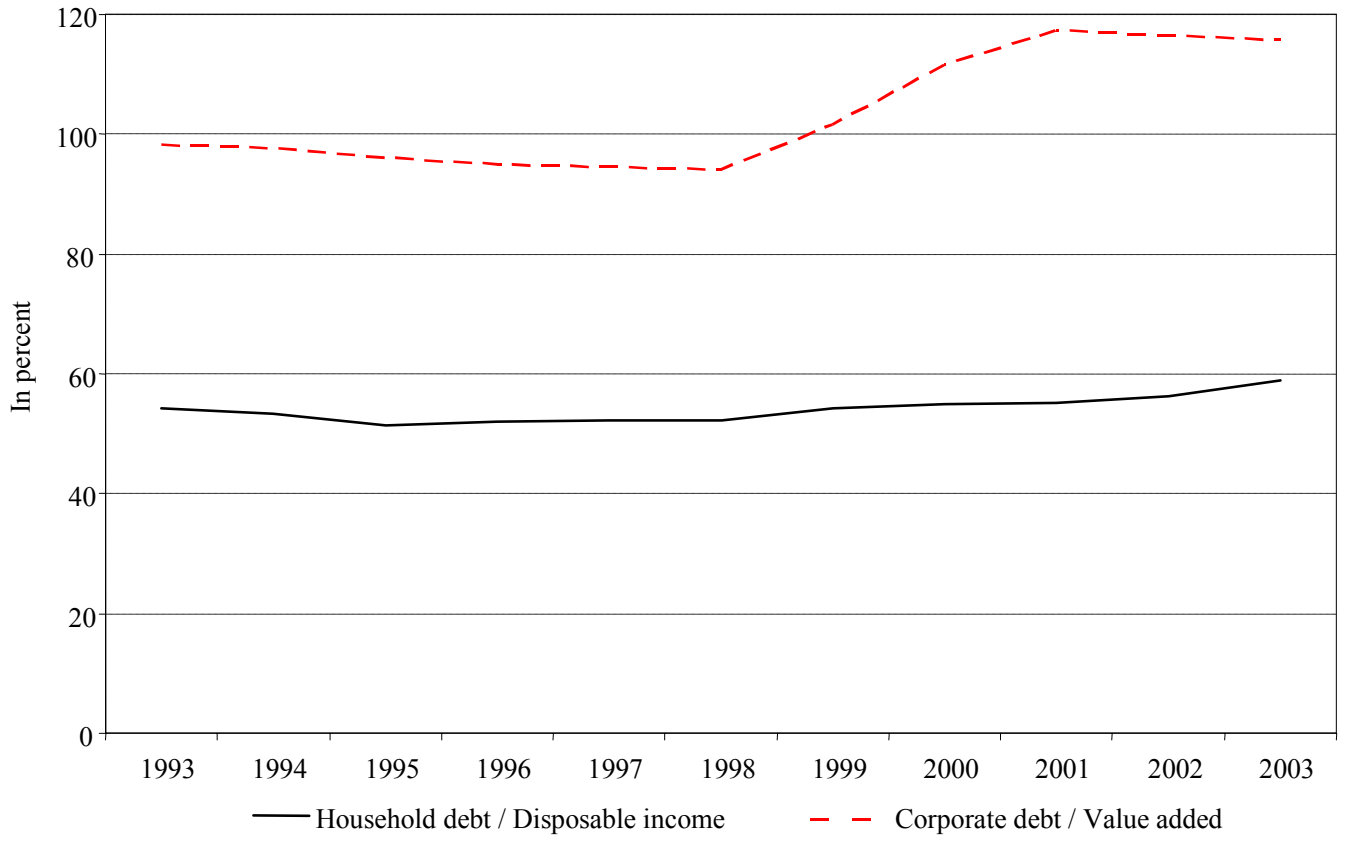

Source: Staff estimates on the basis of BdF and INSEE data.

Figure 2. Financial Sector Structure as of December 2003

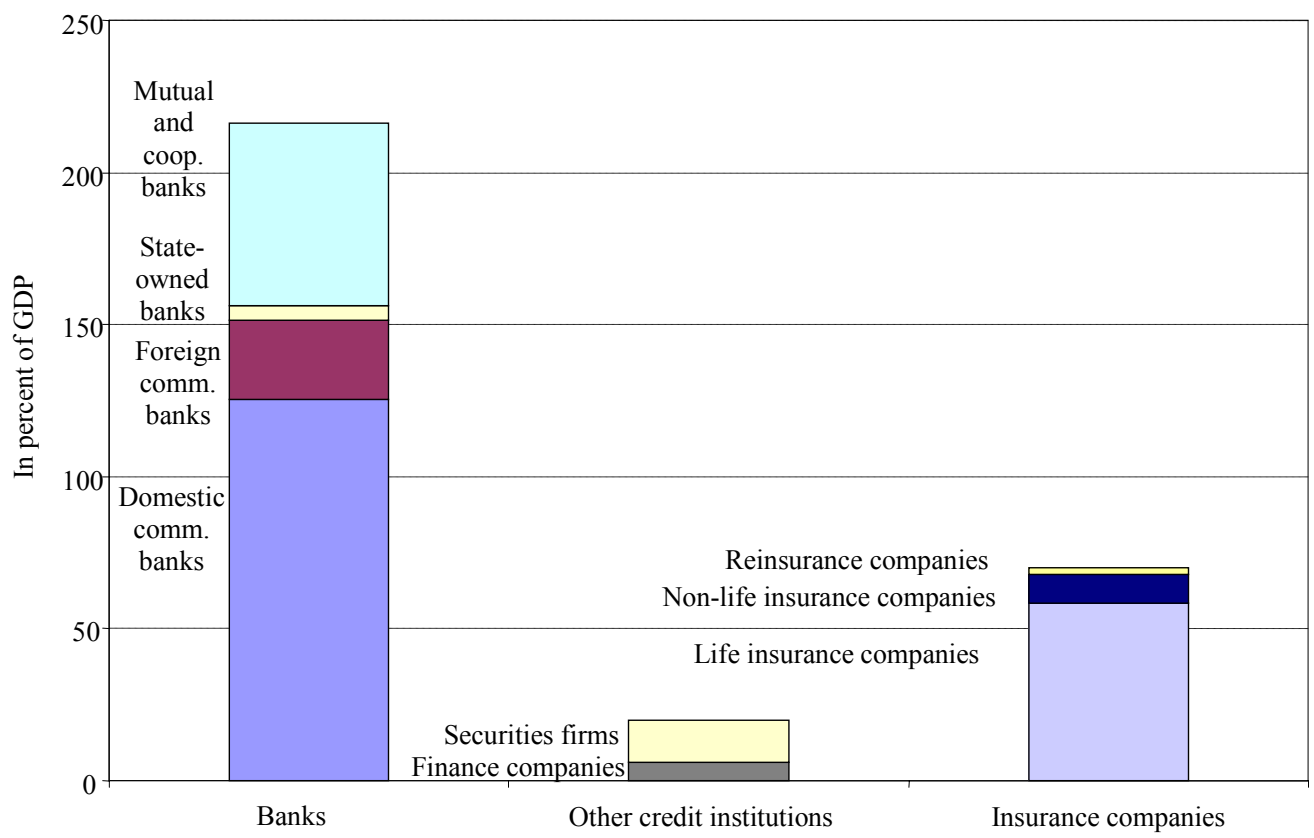

Source: BdF and CCA. 


\section{INSTITUTIONAL AND REGULATORY FRAMEWORK}

\section{Regulation and supervision}

4. Supervision and oversight of the financial sector are of a high standard and supervisory staff is highly qualified. The 2003 Financial Security Law streamlined the number of supervisory agencies and strengthened regulation and supervision of the insurance and securities markets. Reflecting the authorities' choice for a specialized, sector-based approach, separate structures have responsibility for banking, securities and insurance supervision, each comprising distinct institutional layers for regulation, licensing, and supervision.

5. This framework requires close coordination, especially for the large complex financial institutions. Coordination mechanisms across domestic regulators and with foreign authorities will need to be reviewed following the recent reorganization in order to ensure that the new framework enhances effectiveness. Moreover, crisis management protocols formalizing decision-making procedures in the event of a major disturbance would be helpful, in particular because foreign supervisors may be involved.

6. The presence of industry and government representatives on the boards of the supervisory bodies brings practical sectoral knowledge, promotes consensus, and may help facilitate consistency across regulators. However, it also raises concerns of potential conflicts of interest and limited supervisory independence. While such problems have reportedly not arisen so far and safeguards are in place, further arrangements could limit concerns, for example, by making use of industry representatives who would not quickly return to commercial institutions.

7. Updates of the assessments of observance of the Code of Good Practices in Transparency of Monetary and Financial Policies - for banking supervision, deposit insurance, insurance regulation, payments and settlement systems, and securities oversightshow a high overall degree of observance. Disclosure of the annual report of the deposit insurance fund (FGD), including information on its financing, would be desirable. There are currently still some unresolved issues occasioned by the ongoing institutional transition in securities oversight. No stability issues arose in the transparency assessments.

8. The EU is due to adopt International Financial Reporting Standards, which will take effect as of January 2005. However, there is still not full agreement within the EU about the adoption of IAS 39 relating to financial instruments. Some countries, including France, believe that the required greater reliance on fair value could introduce undue volatility in the reported earnings of insurance companies and banks.

\section{Banking sector}

9. Banking supervision meets high standards. Given the importance of large, internationally active institutions in the system, a "reinforced surveillance program" applies to major financial groups, and the authorities cooperate closely with supervisors in other 
major financial centers. Preparations for implementing the Basel II capital accord, which will apply to all banks, are well advanced. Compliance with the BCP is strong; nonetheless, among other issues raised by the BCP assessment, it is suggested that:

- $\quad$ The obligation to obtain prior approval from the CECEI for bank acquisitions of equity in non-financial enterprises should be introduced (measures have been developed but not yet enacted).

\section{Insurance sector}

10. A review of France's observance of the IAIS Core Principles reveals a high level of observance, supported by the quality of the supervisory staff. Main areas where enhancements could be made include the following:

- $\quad$ More responsibility for the drafting and issuing of rules and regulations (in consultation with relevant ministries) should be given to the insurance supervisory agency (CCAMIP), as is the case for other supervisors.

- $\quad$ The staff of the CCAMIP should be increased, mainly because the complexity and scope of its activities has expanded significantly in recent years.

- $\quad$ The CCAMIP should be empowered to issue and enforce a code of conduct of corporate governance, as well as requirements for efficient internal controls beyond those applied in the context of investment policy and risk management systems that cover all material risks.

- The supervision of reinsurers is limited. A comprehensive prudential framework adapted to the reinsurance business should be introduced. To this end, France should anticipate the main elements of the EU directives in this area that are now in development, and plan for their speedy implementation.

\section{Securities markets}

11. France's securities market regulatory landscape has changed in 2003 with the establishment of a new securities regulator, the AMF. The new authority not only inherited the remit and competencies of the authorities it replaced, but also gained additional powers over investment advisors and rating agencies, and in the areas of corporate governance and audit standards.

12. The assessment of IOSCO Objectives and Principles shows strong implementation. However, the following areas require further action, some of which is already en train: 
- $\quad$ Although effective arrangements for cooperation between the AMF and the CB seem to be in place, the law should explicitly require, rather than merely authorize cooperation.

- $\quad$ The presence of a government representative in the AMF's sanctioning body (even without the right to request the rehearing of a decision) has the appearance and the potential to undermine its independence in enforcement. In addition, the AMF should be free to use information from monitoring and inspection activities in pursuing enforcement actions. ${ }^{3}$

- $\quad$ The monitoring frequency of broker-to-client equity positions related to deferred settlement positions (SRDs), essentially margined positions and open exposures, should be increased.

- $\quad$ The oversight of depositories and scope of marketing standards for Collective Investment Schemes (CIS) should be enhanced to strengthen fund-manager accountability for sales. CIS-related on-site inspections need to be extended to depositories, for which additional staff will have to be assigned.

- $\quad$ Existing controls to prevent inappropriate related party transactions and reducing potential conflicts of interest at CIS should be enhanced.

- $\quad$ Protection of minority interests should be improved; for example, changes in beneficial ownership of voting shares below the level of control should be publicized promptly. An EU directive in this area is to be implemented shortly.

- $\quad$ Powers to oversee audit standards and audits of public companies should be augmented to give the AMF a greater role because the new auditing oversight board may not have all capacities needed to enforce auditor independence and auditing and accounting standards.

\section{Payments and securities settlement infrastructure}

13. The infrastructure for payments and securities settlement is highly developed and seems efficient for its users. Observance of the relevant standards (CPSIPS and RSSS) is generally high. Yet, some important issues remain:

\footnotetext{
${ }^{3}$ There are potential judicial rather than regulatory impediments to the AMF's enforcement powers. Specifically, questions have been raised in a recent court proceeding, under the doctrine of impartiality, that might limit the ability of the AMF to use information obtained in the course of its monitoring activities.
} 
- Both SIT and Relit+ are multilateral netting systems that operate without protection against the default of the largest net debtor. The authorities and system operators have already taken steps to address this problem. The mission encourages these efforts.

- Although the availability of the infrastructure is high, the business continuity measures of some systems could be upgraded.

- Some of the systems are tiered, whereby a limited number of direct participants serve as settlement banks for several other financial institutions. Tiered structures can concentrate risk and increase the potential for widespread disruption if any problems occur at a settlement bank. The authorities should evaluate the different aspects of this concentration risk. If warranted by this evaluation, measures should be introduced to reduce tiering and broaden access to these systems.

\section{AML/CFT}

14. France has in place a comprehensive legal and institutional framework that achieves a high level of compliance with the FATF $40+8$ Recommendations. The regime goes beyond the standard in a number of areas, including in sectoral coverage and reporting requirements for the import and export of monetary instruments. Moreover, the regulation and supervision of credit institutions and investment firms other than portfolio management firms ("investment firms") is of a high standard. However, additional measures are required in some areas:

- UNSCR 1373 should be more fully implemented. This is an issue common to other European countries operating within the European Union regulatory framework.

- The scope of the suspicious transaction reporting requirement should be aligned with that of the predicate offences for money laundering.

- All relevant parties should work on improving the number and quality of STRs and the number of STRs transmitted to the judicial authorities. This will involve additional outreach to reporting parties, including those in the Overseas Departments and Territories.

- Regulation and supervision of sectors other than credit institutions and investment firms should be strengthened, and corresponding resources of the relevant agencies increased. Responsibility for AML/CFT supervision and enforcement of la Poste should be shifted to the $\mathrm{CB}$, or, at a minimum, the supervisory efforts and resources of the Inspection Générale des Finances (IGF) should be increased. The authorities should also review and monitor more closely enforcement efforts vis-à-vis unlicensed informal funds transfer systems.

- Refinements should be made to requirements regarding ongoing monitoring of accounts and transactions; the application of AML/CFT requirements to branches and majority- 
owned subsidiaries located abroad; and internal controls for entities other than credit institutions and certain investment firms.

- Additional efforts should be devoted to compiling statistics on mutual legal assistance requests made or received and their outcome, as well as on the amounts of property frozen, seized and confiscated in relation to money laundering, its predicate offenses, and financing of terrorism.

\section{Bankruptcy procedures and property rights}

15. Banks' exposure to potentially bankrupt companies is difficult to manage, as banks may be held liable for "rupture de crédit" (untimely cutting of credit to the company), or "crédit abusif" (undue continuation of credit to an obviously unviable company). The draft law on corporate insolvency is welcome because it is expected to help address the problem. The new bankruptcy rules will also facilitate distressed corporations entering "Chapter 11"style restructuring procedures rather than being forced directly into insolvency (as is roughly the case now). The tendency for courts to interpret the writing off of a loan as meaning that the bank foregoes repayment should be addressed.

16. Writing certain financial contracts often involves expensive notarization. While notaries are an essential element of the legal system, notary and other charges can be substantial, especially for mortgages. ${ }^{4}$ As a consequence, residential loans are often not backed by a mortgage lien but by a "caution" (essentially a third-party guarantee). This mechanism could exclude some lower-income households from financing for home ownership. The authorities may wish to consider how to reduce notary costs for retail clients, especially for routine operations. In this context, they may wish to investigate the legal steps necessary to facilitate home equity loans, which are currently underdeveloped.

\section{FinanCial Sector SoundnesS}

\section{A. Banking Sector}

\section{Market support}

17. The ECB has primary responsibility for liquidity management in the euro currency area. National central banks, including the BdF, retain responsibility for monitoring and forecasting liquidity positions of domestic banking systems, operate standing facilities, and provide emergency liquidity assistance.

\footnotetext{
${ }^{4}$ Tax and notary fees typically amount to about 1.5 to 5.0 percent of the loan value. An additional charge of 0.5 to 2.0 percent is made to release a mortgaged asset ahead of schedule.
} 
18. Liquidity is abundant in the French systems due to: (i) the Eurosystem's policy of allowing banks to use required cash reserves for intraday payments; (ii) the liquidity optimization facilities in PNS; and (iii) the easy access to intraday liquidity facilities of the $\mathrm{BdF}$ and the broad range of eligible collateral. Furthermore, liquidity management is facilitated by the fungibility of funds across banks' accounts held for different settlement systems.

19. The FGD, the deposit guarantee fund, covers deposits up to EUR 70,000 per account holder in all credit institutions licensed in France. It is funded through contributions from the banks, which pay differentiated risk-based premiums.

20. The CB disposes of effective sanctions to enforce prudential rules, and has primary responsibility for bank intervention. When it decides that a bank must be resolved, it mandates the FGD to execute the decision. The FGD can also decide, in consultation with the $\mathrm{CB}$, to take preemptive action. In recent years, the authorities have shown their ability and willingness to take strong action against a number of banks, including through de-licensing and closure. However, the general administrative law makes it relatively easy to obtain a court injunction to stay such intervention. While French banks have reportedly not used this to block supervisory action, experience in other countries shows that this is a weakness that should be corrected.

\section{Recent performance}

21. With Tier I risk weighted capital at about 10 percent, bank capitalization is strong, and has allowed banks to finance consolidation without large borrowing. Reported bank asset quality has been stable throughout the recent economic downturn, due to the sound state of household finances, the low level of interest rates, and the moderate credit expansion. However, some large French nonfinancial corporations are financially vulnerable, owing to debt-financed expansion. As the banks themselves and the supervisory authorities are aware, this could pose risks for individual banks. Banks hold large and mostly fixed-rate mortgage portfolios. Historically, the prevalence of guarantees, collateral and unemployment insurance has limited direct credit risk, but bank profitability could be squeezed if funding costs rise. ${ }^{5}$ Being important players on international financial markets, French banks do have some exposure to market risks. The inherent counterparty risk of banks' off-balance sheet items is estimated at a modest 3 percent of total weighted risks, despite the huge notional amounts involved, and the $\mathrm{CB}$ is confident that the risks are well understood, monitored and contained.

22. Although not particularly strong, bank profitability has improved markedly over the past decade. Average ROA and ROE (return on assets and equity) remain below those in the

\footnotetext{
${ }^{5}$ The guarantees ("caution") are granted by specialized companies, some of which, however, are subsidiaries of banks.
} 
United States, the United Kingdom, and Spain but are equal or superior to those in some other major countries. Net fees and commissions have become increasingly important sources of revenues. Cost-to-revenue ratios have fallen in recent years, to about 65 percent now, in line with European averages. Nevertheless, the system's fixed-and labor-costs remain high. ${ }^{6}$

\section{Stress tests}

23. Stress tests suggest that the financial system is resilient. These tests estimate the possible effects on banking and insurance of short-term shocks to market variables and credit quality, and those of several longer-term macroeconomic scenarios (Appendix II, and Table 6a). The shocks were calibrated based on the magnitude of the largest shocks experienced in the last 25 years. Results cover banks and insurance companies comprising more than three quarters of each sector's assets.

24. No test showed any bank's capital adequacy ratio falling below the required 8 percent level, and any loss could be made up out of profits at 2003 levels. A general deterioration in credit quality, which might be connected with a prolonged fall in world demand, would have the largest and most widespread effect. A few individual banks might be hard-hit by a stock market crash. A rise in oil prices and the ensuing slowdown in growth would affect banks negatively, but the impact would be moderate. Banks would not have to provide large sums to recapitalize their insurance subsidiaries.

\section{B. Insurance Sector}

25. Available sector soundness indicators show adequate average levels of solvency and profitability (Tables 4 and 5). This may help limit vulnerability to macroeconomic risks typical of the insurance sector. Other sources of stability include:

- $\quad$ Conservative investment portfolios, with fixed-income instruments consistently representing the largest share. Hence, the sector has not been greatly affected by equity price declines since 2001 .

- $\quad$ The life segment has shifted much investment risks to policyholders by lowering guaranteed interest rates, reducing the duration of contracts, and introducing unitlinked products.

- $\quad$ The insurance sector has limited exposure to other financial sector components and in particular banks. Rather, a large share of life insurers is subsidiaries of bancassurance groups led by banks. Furthermore, acquisition of credit risk through use of derivatives is still extremely limited (Box 2).

\footnotetext{
${ }^{6}$ Large numbers of employees are expected to retire starting in 2005, which should help reduce the cost base.
} 
- The domestic reinsurance sector is relatively small. Insurers transfer significant risk to reinsurers abroad. In the case of high cost-low probability risks (such as major natural disasters), companies have access to state-guaranteed (and sometimes statemanaged) reinsurance schemes.

\section{Box 2. Credit Risk Transfer Activities}

Credit risk transfer (CRT) activities have grown in France, as is the case in most other major economies. According to a study by the French authorities (published in the Banque de France's June 2004 Financial Stability Review), as of June 2003, the French financial system was a net seller of credit protection (EUR35 billion), with large differences across financial players in both the type of risk transfer instruments used and reasons for their use. French banks are net buyers of credit protection, largely in the form of single name credit default swaps (EUR60 billion, roughly 6.5 percent of their total loan exposure), which they buy primarily to diversify the corporate concentration risks and thereby reduce regulatory capital requirements. The use of credit derivatives by French insurance companies is found to be insignificant, but they are significant net protection sellers in the form of structured debt instruments such as mortgage-backed securities and collateralized debt obligations (EUR13 billion or 2 percent of their total assets), and financial guarantees (EUR40 billion, or 7 percent of their total assets), the latter offered by specialized insurers. Insurers' limited use of credit derivatives seems to be partially influenced by the new international accounting standards, which induce them to structure the transaction as a financial guarantee, which can be recorded as a liability, thus avoiding the need to value the risk exposure at market prices.

The greater use of CRT instruments has in principle allowed for a more effective and stability improving dispersion of credit risk across the financial system. However, as is the case in most economies, the actual amount of credit risk transferred out of the banking system remains relatively small in comparison to total assets on banks' balance sheets. In addition, CRT activities have raised counterparty risks, as French banks active in the credit derivatives market necessarily become exposed to the solvency risk of a few large U.S. banks that play a central role in this market. A drawback of the study is that it reports almost exclusively the notional amounts of credit risk transfer activity, which, in the case of tranched credit instruments in particular, provides a very inaccurate measure of the actual level credit risk being transferred. ${ }^{1}$ For the insurance companies, their CRT activities have introduced a new risk transfer channel and increased interlinkages with the French banking sector, since most of their financial guarantees are sold to French banks.

1/ The study acknowledges this shortcoming.

\section{Stress tests}

26. Stress tests similar to those performed for banks showed that no insurance company would suffer an immediate loss, largely because most of the risk is borne by policyholders (Appendix II and Table 6b). Also, exposure to claims arising from natural catastrophes is limited by reinsurance coverage. However, over the long term, life insurers could be affected by a sharp and sustained rise in interest rates that could prompt policyholders to shift funds to other assets, and therefore force insurers to sell assets before maturity and realize losses. However, the effect appears manageable and the authorities are well aware of the issue, which constitutes one main theme of the mandatory stress tests introduced in 2001. 


\section{Structural IsSUES ANd Financial Sector EFficiency}

\section{Financial sector policy and mandated savings schemes}

27. The numerous government schemes and provisions affecting the composition and allocation of savings have been driven by legitimate policy objectives such as protecting small savers and financing social housing and local facilities. ${ }^{7}$ However, the cost-benefit ratio may be high because the schemes are often inadequately targeted, and generate externalities (Appendix III). Furthermore, they have not been fully adapted to changing needs such as reinforcing the pension system as demographic pressures mount.

28. Reform of these schemes is desirable in order to (i) eliminate price distortions; (ii) eliminate distortions to competition; (iii) reduce the centralization of deposits; (iv) reduce the constraints and risks the schemes impose on the banking system; (v) refocus any remaining schemes on priorities for the future, and (vi) enhance the monetary transmission mechanism. ${ }^{8}$ The resulting improvement in allocative efficiency would contribute to trend growth. Some important steps have already been taken, such as the December-2002 reform of the PEL and last year's introduction of a new mechanism to adjust the remuneration of the livret A.

29. For the reasons enumerated above and because increased international financial integration may raise the economic cost of the schemes, the administered savings schemes should be phased out and other government involvement in the allocation of savings curtailed. Other, more market-friendly or budgetary mechanisms should be considered to finance the retained public policy objectives. ${ }^{9}$ Efforts to further develop pension savings vehicles (such as PERPs) should continue to be a priority.

\footnotetext{
${ }^{7}$ The schemes and provisions include a number of types of passbook savings account ("livret"), savings schemes for home buying (PEL and CEL), the ni-ni rule that prohibits the payment of interest or charging for checkbooks, and a variety of special tax rules. A fuller description and impact on monetary policy transmission (see also paragraph 28) is available in the chapter "Public Intervention in Financial Markets: Obstacles to Monetary Transmission?" of the accompanying Selected Issues document. See also Appendix I.

${ }^{8}$ The chapter "Public Intervention in Financial Markets: Obstacles to Monetary Transmission?" of the accompanying Selected Issues document provides quantitative evidence on how those schemes impede monetary policy transmission to market rates. In particular, the analysis suggests that over the last three years, up to $3 \frac{1}{4}$ percentage point of potential consumption growth could have been forgone because of the slow adjustment of consumption credit rates, out of which half is attributable to the sluggish adjustment of administered saving rates to monetary policy changes.

${ }^{9}$ For example, the CDC could issue bonds to finance social housing construction as a replacement for savings collected through the livrets.
} 
30. A gradual approach to the unwinding of existing schemes, especially the large ones such as the livret A and the PEL, should be considered so as to limit potential risks, honor existing contracts, and forestall the potential fiscal costs of preemptive withdrawals from existing schemes. To this end, the following short-term measures would be appropriate: ${ }^{10}$

- abolishing the ni-ni rule prohibiting the payment of interest on current accounts and charging for checkbooks;

- abolishing or significantly relaxing the usury rate;

- ending the oligopoly on distribution of the livret $\mathrm{A} / \mathrm{bleu}$, preferably by merging all or most existing livret schemes into a single product with uniform tax treatment;

- aligning the rates on the livret $\mathrm{A}$ and PEL deposits even closer to market rates, for example, by adjusting them every time the ECB changes its policy rates;

- defining the guaranteed mortgage interest rate in new PEL contracts relative to the level of a benchmark market rate at the time the loan is taken up;

- allowing the financial section of La Poste to manage its own balance sheet, as planned, and reconsidering the need for other funds to be centralized at the $\mathrm{CDC}$;

- either terminating the availability of new PEL accounts, or at least removing their tax advantages, which would enhance the relative attractiveness of PERPs (personal retirement plans). The scope for reducing the costs of moving funds from existing PEL accounts into PERPs should be investigated.

\section{Banking sector concentration and governance}

31. Available quantitative indicators do not suggest that recent bank consolidation in itself has had a significant negative impact on the degree of competition in the market, except possibly in some localities. However, retail-level competition seems focused on a limited set of products and parameters. In particular, banks price mortgage loans aggressively with a view to attracting customers to which they can profitably sell high-margin products. ${ }^{11}$ Banks' ability to retain long-term customers appears to be strengthened by the cost of refinancing mortgages, limited transparency and information availability, and cultural factors. Such strategies may in part be motivated by the requirement to invest all PEL/CEL deposits in specified uses (mainly mortgage loans), and because the administered savings schemes could put downward pressure on mortgage interest spreads.

${ }^{10}$ The current low interest rate environment would facilitate their implementation.

${ }^{11}$ After the FSAP missions, the EU Commission announced an investigation of collusion in the provision of payment card services. 
32. Selling several products to each client has allowed French banks to be profitable despite their low interest margins. Individuals often buy financial products in bundles. Such practices may reflect economies of scope. However, without price transparency, bundling could also be used to restrain competition. Thus, it would be helpful to require banks to make publicly available their schedule of interest rates and fees, and for competition authorities to be prepared to act forcefully in case of anti-competitive practices. Introducing the proposed positive credit register would promote the availability of financial services for households and small and medium enterprises and competition among providers.

33. Besides competition concerns, further merger activity among the big domestic bank groups would reinforce the impression that they are too big to fail, and the consequent risk of moral hazard (in addition to competition concerns). ${ }^{12}$ The CB and the CECEI need to remain vigilant in analyzing any new merger proposal, and be ready to oppose those that would increase systemic risks. The expansion of La Poste's banking activities and subjecting it to normal prudential regulations will be demanding of CB resources (Box 3).

34. The growth of the mutual groups has raised some issues in several countries in the areas of governance and recapitalization - if they run into difficulties because they cannot readily raise fresh capital from their members. Moreover, the riskiness of their operations is likely to increase as they undertake lines of business removed from local retail banking, where their comparative advantage generally lies. The mutual groups typically comprise a number of regional member banks - that are owned by millions of members - and a central unit. French mutual banking groups have systems of checks and balances that allow the regional member banks to scrutinize the activities of the central unit, which have countervailing supervisory powers over regional banks and largely direct strategy. The CB supervises groups on both a consolidated and a disaggregated basis.

35. Nonetheless, given their peculiar structure, French mutuals could raise some governance issues given the decision-making process, which relies on both top-down and bottom-up approaches. However, outside scrutiny of mutuals has increased in recent years, as they have started to finance themselves in the markets through the issuance of bonds and of shares in subsidiaries.

${ }^{12}$ Market participants already seem confident that the authorities would intervene if a large bank got into difficulties. Euronext is also considered to be a (non-deposit-taking) credit institution and as such could also be viewed by market participants as benefiting from a government "safety net" guarantee. 


\section{Box 3. Restructuring La Poste's Activities}

La Poste is a public entity, whose activities, on top of postal and courier services, encompass some basic financial services. With 8 percent of total deposits, 10 million checking accounts and 17,000 postal outlets, La Poste has one of the most extensive banking networks in France, which it maintains with the help of subsidies related to its social mandate to cover the entire country. However, as it currently does not have the statute of a bank, it falls outside the supervision of the CB.

In the context of eroding market shares and with the full liberalization of the postal service scheduled for 2009, the authorities have decided to separate La Poste's financial services into a separate public bank (provided it receives the bank license from CECEI). To compete with private banks, La Poste has asked to be able to sell a wider range of financial products. In a first stage, the authorities have only agreed to La Poste offering mortgage loans without prior savings. ${ }^{1}$

The overall impact on competition of the contemplated reform hinges on the clarification of its financial relationships with the postal branch of La Poste. The measure goes in the direction of a more level playing field, by (i) having the postal bank fall under CB supervision; and (ii) phasing out its current blanket state guarantee in the next two years. However, the network and human resources provided by the postal branch of La Poste will have to be accounted for and charged to the postal bank on a fully commercial basis in order not to give it an undue competitive advantage. This is likely to be difficult, given the large fixed cost component; sharing non-assigned costs in proportion to revenue, as has been mooted, could be far from first-best. Leveling the playing field will also require phasing out La Poste's current preferential tax status, and eliminating the oligopoly on the distribution of certain savings products, as recommended elsewhere in this report.

Reinforced scrutiny should be applied by the regulatory body during the early years of La Poste's new bank activities. In that respect, the supervision of the large network of the postal bank may entail a large burden on the CB. The regulatory obligation to channel large amounts of PEL deposits into mortgage loans, a task previously done at the $\mathrm{CDC}$ level, may push the postal bank in risky lending.

Over time, a candid assessment of the impact of the postal bank reform will be required. La Poste should be able to exhibit sound assessment of credit risk and prospects for achieving a market return on its capital, as a requirement to stay in business, particularly if the scope of its operations were to be expanded. More broadly, however, from a banking perspective it is difficult to make the case for a new, full-fledged public bank. Its eventual privatization should be considered.

${ }^{1}$ So far, La Poste can only grant market mortgage loans as a supplement to PEL loans.

36. The combination of an increased focus on profitability and mechanisms that keep the disbursement of profits low (compared to commercial banks) means that mutual groups have in recent years accumulated capital at an accelerated pace. ${ }^{13}{ }^{14}$ In coming years, lower capital

${ }^{13}$ Legal restrictions on payouts differ across mutuals. For example, legislation restricts one of them from paying dividends at a rate above the government bond yield. Share buybacks at the initiative of management are effectively impossible.

14 The payout ratio of the mutual banking groups has been around 10 percent, as against 30-35 percent at the large commercial banks. Ex post capital ratios have not increased strongly because of equity-financed acquisitions. 
requirements of many banks under the new Basel II rules, combined with robust profitability, low nominal growth in credit, and securitization may generate more "excess" capital (not only for mutuals and not only in France). That may, paradoxically, give rise to stability concerns if bank management uses the resources for hasty expansion and acquisitions in activities with unfamiliar risks. Experience in other countries suggests that over-ambitious ventures rapidly consume capital. In the case of France, however, mutual groups' core activity still remains domestic retail business. When expanding into new activities, central bodies of mutual groups have, in some cases, acquired specialized groups in corporate finance, market risks, and international activities, in part in order to acquire relevant expertise.

37. The CB is fully aware of the above issues related to mutual groups, and exerts strong surveillance over these institutions. To reduce these risks while monitoring the behavior and internal governance mechanisms of the mutual groups, further exposure of the mutuals to market incentives - for instance, by listing subsidiaries - should be encouraged. Removing legal obstacles to higher remuneration of members (e.g., through dividends or share buybacks) would help reduce excess capitalization and pressure on mutuals to expand. It would also be useful to reconsider the legal impediments to demutualization, offering mutuals a way to demutualize without having to surrender all of their reserves.

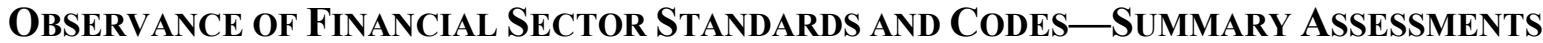

This annex contains summary assessments of international standards and codes relevant for the financial sector. The assessments have helped to identify the extent to which the supervisory and regulatory framework is adequate to address the potential risks in the financial system.

The following assessments of financial sector standards were undertaken:

- The Basel Core Principles for Effective Banking Supervision (BCP), by Mr. Jan Willem van der Vossen (IMF/MFD);

- IAIS Insurance Core Principles (ICP), by Mr. Helmut Müller (Former BAV, Germany) and Mrs. Andrea Maechler (IMF/MFD), using the ICP methodology adopted in October 2003;

- The IOSCO Objectives and Principles of Securities Regulation, by Mrs. Andrea Corcoran (CFTC), using the methodology adopted in October 2003;

- The CPSS/IOSCO Recommendations for Securities Settlement Systems, by Mr. Jan Woltjer (IMF/MFD), using the methodology adopted in November 2002;

- The CPSS Core Principles for Systemically Important Payment Systems, by Mr. Jan Woltjer (IMF/MFD) and Daniel Heller (Swiss National Bank), using the methodology adopted in August 2001.

- The IMF Code of Good Practices on Transparency in Monetary and Financial Policies, by Mr. Wim Fonteyne (IMF/MFD) with sectoral experts; and

- The FATF Recommendations for Anti-Money Laundering Combating the Financing of Terrorism (AML/CFT), by Mr. Richard Lalonde (IMF/MFD), Mr. Nadim Kyriakos (IMF-LEG), Mr. Ludovic D'Hoore (Cellule de Traitement des Informations Financières), and Mr. Philippe Fleury (Autorité de contrôle en matière de lutte contre le blanchiment d'argent). The assessment was conducted on the basis of the October 2002 common methodology endorsed by the FATF and the IMF.

The assessments were carried out during a mission to France from January 28 to February 10, 2004, with the exception of the AML/CFT assessment, which was carried out from April 7 to 20, 2004. Additional information was added during the review process. All the assessments were based on the laws, regulations, 
policies and practices in place at the time the assessments were made.

The assessments were based on the following sources:

- Self-assessments by the supervisory authorities;

- Reviews of relevant legislation, decrees, regulations, policy statements and other documentation;

- Detailed interviews with the supervisory authorities;

- Meetings with other authorities and independent bodies, including the Ministries of Finance, Justice, and Social Affairs and Employment, in addition to Euronext, Euroclear France, Clearnet, private operators of payment systems (CRI and SSIT), the Bankers Association, the Actuarial Society, the Institute of Registered Accountants, and auditing firms. 


\section{Basel Core Principles for Effective BANKIng SUPERViSion}

\section{General}

38. This review covers the activities of the key banking regulatory and supervisory bodies in France, in particular the Banque de France (BdF), the Commission Bancaire (CB), the Comité des Etablissements de Crédit et des Entreprises d'Investissement (CECEI), and the Comité de la Réglementation Bancaire et Financière (CRBF). The review was prepared on the basis of the Basel Core Principles Methodology, the April 2000 self-assessment by the French authorities, the August 2001 MAE assessment, information provided by the French authorities on how the recommendations of the 2001 assessment had been addressed, and the response to the pre-FSAP questionnaire. Furthermore, the mission studied laws and regulations relative to banking regulation and supervision, and held discussions with representatives of the regulatory and supervisory agencies, as well as with representatives of the major banks, rating agencies and of the accounting and auditing profession. Also, annual reports of the relevant agencies were consulted, as well as websites of the major banking groups, and other sources.

\section{Institutional and macroprudential setting, market structure—an overview}

39. France has chosen a specialized, sector-based approach to financial sector supervision, with separate structures for banking, securities and insurance supervision, each comprising distinct institutional layers for regulation, licensing, and supervision. Steps have been taken to streamline the supervisory structure, and additional steps may be considered as cross-sectoral financial groups become more prevalent. The presence of industry and government representatives in the boards of the supervisory bodies brings practical sectoral knowledge, promotes consensus, and may help facilitate consistency across regulators. However, it also raises concerns of potential conflicts of interest and limited supervisory independence, although such problems have reportedly not arisen in the recent past and safeguards are in place.

40. The French banking system, which has been modernized and restructured over the past two decades, is large, sophisticated, and of international importance. It is dominated by six vertically integrated universal banks and their subsidiaries. Four of the six are organized on a mutual basis. Further consolidation of the sector could pose a range of challenges, including stability concerns that many banks are "too big to fail." Two large financial institutions, La Poste and the Caisse des Dépôts et Consignations (CDC), remain in government ownership.

41. The banking sector is well capitalized. The reported level of nonperforming loans was stable throughout the recent economic downturn. Bank profitability has improved markedly over the past decade and is in line with average euro-area levels. 


\section{General preconditions for effective banking supervision}

\section{Macroeconomic soundness and stability}

42. After a slowdown in economic activity during 2002-2003, a cyclical recovery has been gathering pace. Inflation has only moderately picked up and ex-post real interest rates have sunk to unusually low levels. Despite slow growth up to mid-2003, the financial situation of the corporate sector has deteriorated only slightly since 2000 and, except for a few large companies, corporate leverage is generally low. Likewise, households' debt levels relative to incomes and assets are comparatively low (albeit rising), and savings rates are high. However, low interest rates and rising prices may induce households to take out larger mortgage loans, which may impact on their future financial position. ${ }^{15}$ Equity prices remain below their 2000 highs, despite the recent recovery, but some investors enjoy offsetting gains on bonds. Commercial real estate prices have remained stable following the early-1990s boom-bust cycle.

\section{Public infrastructure and institutional arrangements for supervision}

43. The legal and regulatory framework for banking supervision is clear, easily accessible and updated periodically. The legal framework to conduct banking business is also well developed, with clear and concise legislation, although legal procedures are lengthy. The legal profession and the judiciary are of high quality and understand financial and banking issues. The accounting and auditing professions are well regulated, and subject to rigorous training and entry requirements.

44. Banking supervision is exercised by the CB, the CRBF and the CECEI. The Minister in charge of the Economy will replace the CRBF as the regulatory authority later in 2004.

45. Independence of banking supervision, with an autonomous board, is generally adequate, although we can note the presence of the Director of the Trésor on the board of the $\mathrm{CB}$. Furthermore, presence of industry representatives on the Boards of the CECEI raises the question of a potential conflict of interest for these members. The authorities stress however, that adequate measures have been taken to mitigate this potential problem. Although the BdF controls the resources of the $\mathrm{CB}$ and the CECEI, linkages between the $\mathrm{BdF}$ and the $\mathrm{CB}$ do not appear to be a matter for serious concern in terms of independence of these authorities. Legal protection of supervisors is well recognized under administrative law in France.

\section{Market discipline and governance}

46. Accounting rules and regulations can be considered generally appropriate, and in line with European and international standards. The authorities have taken a number of actions to

${ }^{15}$ Housing prices have been increasing at an annual rate of 10 percent since 1997 . However, in nominal terms they are not far above the peak reached in 1989. 
enhance convergence between International Financial Reporting Standards (IFRS) and the French accounting standards. A more systematic approach to, and more disclosure of nonperforming loans have been introduced. Credit institutions need to communicate sooner with the $\mathrm{CB}$ when difficulties arise.

\section{Problem resolution}

47. The CB has adequate enforcement capacity, based on (i) good coordination arrangements between on-site and off-site supervisors and with other financial sector supervisory bodies, (ii) a flexible and comprehensive set of notification and corrective action procedures, (iii) effective follow-up, and (iv) sound legal and other enforcement powers. Bank intervention mechanisms have been improved with the reform of the deposit insurance system, according to which the $\mathrm{CB}$ can request the Fonds de Garantie des Dépôts (FGD) to intervene in a bank.

48. The FGD replaces the previous separate guarantee funds. The FGD guarantees deposits and other nominally repayable funds deposited in any registered credit institution in France, up to a ceiling of Euro 70,000 per customer, per bank.

\section{Main findings}

49. Banking supervision in France meets high standards. Compliance with the BCP is strong; among other issues raised by the $\mathrm{BCP}$ assessment, it is suggested that the obligation to obtain prior approval from the CECEI (the licensing agency) for acquisitions of equity in non-financial enterprises by banks be introduced (measures have been developed but not yet enacted.)

\section{Objectives, autonomy, powers, and resources (CP 1)}

50. The CB and the CECEI are independent administrative authorities, and their governance is subject to checks and balances that help maintain their operational autonomy. The legal framework for banking supervision in France is primarily laid down in the Code Monétaire et Financier (Monetary and Financial Code), and related regulations and instructions, which clearly authorize the CB, the CECEI and the Minister in charge of Economy to perform supervisory, administrative and regulatory functions with regard to the banking system in France. The CB is authorized to apply sanctions to banks, including warnings, injunctions, appointment of an official administrator or a liquidator in case a license is withdrawn. Staffing levels are considered adequate, and the overall level of training of supervisory staff is high.

\section{Licensing and structure (CPs 2-5)}

51. Bank licensing rules in France are adequate and consistent with the rules of the First and Second EU Banking Directives, consolidated in EU Directive 2000/12. They comprise requirements with regard to minimum capital, a business plan, information on clarity and appropriateness of banks' organizational structure, fit and proper requirements for managers, 
Board members and shareholders. Licensing applications and withdrawals are dealt with by the CECEI. Approval of the CECEI is required to acquire shares in a bank that exceed a predetermined level. Corporate structure of a group to which a bank belongs must be transparent and not hinder supervision. Non-compliance with this criterion is a ground for license refusal or revocation.

\section{Prudential regulations and requirements (CPs 6-15)}

52. French requirements with regard to capital adequacy of banks are fully in line with the 1988 Basel Capital Accord and EU directives. The CB and the CECEI may require higher capital ratios in individual cases, when justified by the risk profile of an institution. Regulations set criteria for the quality of banks' lending practices and policies. Banks' lending practices are monitored through off-site analysis and on-site inspections. Monitoring of group exposures also requires that banks provide an analysis by geographical region.

53. Transactions with related parties are dealt with in the Commercial Companies Act, and are subject to full Board authorization. When connected lending exceeds 5 percent of own funds, reports must be filed to the CB. Country risks, market risks, foreign exchange risks and operational risks are fully covered by regulation and monitored on a monthly basis. Measures have been taken to strengthen corporate governance in banks.

\section{Methods of ongoing supervision (CPs16-20)}

54. The General Secretariat of the CB carries out off-site monitoring and on-site supervision, through separate directorates for off-site, on-site and policy development. Contacts with the banks are frequent, both in the context of the inspection process, as well as ad hoc, between banks' top management and the Secretary General of the CB and his/her deputy. The $\mathrm{CB}$ defines the statistical and prudential information and documentation that banks are to submit regularly, as the basis for off-site analysis. The large mutualist groups also report on a consolidated basis. Banks' information is verified through off-site analysis and on-site inspection. Furthermore, an annual external audit is required. If the CB has strong objections against a bank's financial statements, it has the authority to order a rectification.

\section{Information requirements (CP 21)}

55. In 2005, IFRS are to become the norm for financial disclosure within the EU, although IAS 39 on fair value accounting is still a contentious issue between the International Accounting Standards Board and the EU, and notably France. Since the issuance in 1998 of a report of the Securities Commission on accounting standards in France, a program has been established to improve financial accounting in France, and important implementation measures have been undertaken by the authorities. In its 2001 Annual Report, the CB performed a preliminary analysis of the changes required in French financial accounting, and wishes to sensitize French banks to the need to adapt to more internationally recognized standards. 


\section{Formal powers of supervisors (CP 22)}

56. The CB has a broad range of enforcement and sanctioning powers at its disposal: the most common and effective means to obtain remedial measures are the follow-up letters (lettres de suite) following an on-site inspection. They rely on both management and the Board of Directors to ensure correction of the situation. Pecuniary sanctions may also be imposed upon the bank in addition to these measures. Moreover, the CB may impose the withdrawal of the voting rights of certain or all shares, the prohibition to pay dividends or other form of remunerations to shareholders and the obligation for the credit institution to disclose, at its own expenses, the disciplinary sanctions. The CB may mention infringements or criminal offenses to the Public Prosecutor's Office. The CB is an administrative judiciary authority, and its decisions and sanctions can therefore only be challenged before the Conseil d'État, the highest administrative judicial authority in France. In its annual report, the CB provides information - without mentioning names of banks - on the sanctions it has imposed.

\section{Cross-border banking (CPs 23-25)}

57. Banks and their holding companies are obliged to comply with the prudential standards on a consolidated basis, including the controlling entity and its subsidiaries. The $\mathrm{CB}$ and the CECEI have established an extensive network of Memoranda of Understanding (MOU) with supervisory authorities abroad. Information on individual institutions is regularly exchanged between the $\mathrm{CB}$ and non-EEA ${ }^{16}$ supervisors. Under the EU single banking passport rules, branches of banks in the European Economic Area, European regulation are covered by home-country supervision. Branches of non-EEA banks are subject to the same rules and regulations as French banks. Subsidiaries of foreign banks are fully subject to French rules and regulations, as such institutions are incorporated under French law.

Table 1. Recommended Action Plan to Improve Compliance of the Basel Core Principles

\begin{tabular}{|l|l|}
\hline \multicolumn{1}{|c|}{ Reference Principle } & \multicolumn{1}{c|}{ Recommended Action } \\
\hline Investment criteria (BCP 5) & $\begin{array}{l}\text { Introduce the obligation to obtain prior approval of the CECEI } \\
\text { for acquisitions of equity in non-financial enterprises by banks } \\
\text { (measures have been developed but not yet enacted). }\end{array}$ \\
\hline Corporate Governance in Banks (BCP 13) & $\begin{array}{l}\text { Continue to follow carefully any initiatives for expansion of } \\
\text { the large banking organizations in a time of change, new } \\
\text { activities and increased depositor mobility, notably for } \\
\text { mutualist groups with recent experience in these new } \\
\text { activities. }\end{array}$ \\
\hline Accounting Standards (BCP 21) & $\begin{array}{l}\text { Continue to strive towards convergence between French } \\
\text { accounting standards and IFRS. }\end{array}$ \\
\hline
\end{tabular}

${ }^{16}$ European Economic Area, comprising all EU members plus Iceland, Norway and Liechtenstein. 


\section{Authorities' response}

58. The authorities are broadly in agreement with the assessment.

\section{IAIS Insurance Core Principles}

\section{General}

59. The assessment of observance of the IAIS Core Principles involved the review of: (i) an extensive self-assessment prepared in 2000 by the former Commission de Contrôle des Assurances (CCA), based on the old methodology; (ii) comparison with the Core Principles and the Core Principles Methodology; and (iii) a review of the relevant laws governing the insurance sector in France. The legal basis governing insurance is the Code des Assurances (as amended), which includes numerous decrees and implementation regulations, and the recent Loi de sécurité financière (Financial Security Law).

60. The assessment was undertaken during a period of transition. On the one hand, the Insurance Core Principles (ICP) are relatively new and were revised in 2003. On the other hand, the French supervisory environment has been significantly modified by the Financial Security Law of August 1, 2003. This legislation created a single supervisory body by merging the CCA, responsible for the supervision of companies regulated by the insurance code, and the Commission de Contrôle des Mutuelles et des Institutions de Prévoyance (CCMIP), responsible for the supervision of certain mutual insurers and provident institutions. The provisions of the law also gave financial independence to the new body, the Commission de Contrôle des Assurances, Mutuelles et Institutions de Prévoyance (CCAMIP), strengthened coordination with the banking sector supervisors, and extended the powers of the supervisory authorities to request and receive information from supervised entities and auditors. The implementation orders (décrets d'application) for the new law were under review by the Conseil d'État at the time of the assessment, and as of July 2004 the transition period has ended.

\section{Institutional and macroprudential setting-an overview}

61. The French insurance sector is large and of systemic importance. With a 5 percent market share of gross premiums in the OECD in 2001, France's insurance sector was ranked the fifth largest in the world and the third largest in Europe. Overall, the condition of the French insurance industry suggests that systemic vulnerabilities are well contained. The sector seems to have demonstrated its resilience in the face of a number of significant shocks in recent years (including, among others, a significant fall in international equity prices in the period 2001-2003, historically low interest rates, and international and national natural catastrophes). However, the industry faces a number of longer-term challenges connected with: (i) the demographic trend (longer life expectancy and decline in working population); 
(ii) the upcoming implementation of the new International Financial Reporting Standards (IFRS) in 2005, which some in the industry believe expose it to accounting risks; and (iii) the possibility of a sharp and sustained increase in interest rates, which could generate a wave of contract repurchases. However, the authorities seem aware of these challenges and are considering how to take preemptive measures, such as the promotion of a new generation of private retirement products.

\section{Main findings}

62. The legal, regulatory, and supervisory framework observes a large majority of the essential criteria of the IAIS Principles Methodology.

63. The preconditions for effective insurance supervision are observed. Areas where improvements could be made can be grouped into five broad categories.

\section{Corporate governance, internal controls, and risk management systems}

64. Many but not all of the principles of corporate governance are established in several regulations. It is recommended that the CCAMIP should have the authority to issue a Code of Conduct of Corporate Governance for all insurance companies supervised by this authority. This suggested Code of Conduct should also contain the requirements for efficient internal control that must be respected by all supervised insurance companies.

65. Current regulations on internal control focus mainly on investment policy and the preparation of a limited report. The supervisory authority cannot require and directly enforce some of the measures and systems which are mentioned in the ICP and which are necessary for an efficient internal control.

66. The legislation should require that all insurance companies establish risk management systems which touch on all material risks. The supervisor should have powers to require that all supervised entities establish an effective risk management system appropriate to the complexity, size, and nature of the insurer's business.

\section{Structure of the supervisory agency}

67. The new framework for regulation and supervision seems rather segmented since four different bodies are involved: (i) the Ministry of Economy, Finance, and Industry (MINEFI) for regulation; (ii) the Comité des Entreprises d'Assurance (CEA) for licensing, delicensing and related issues; (iii) the CCAMIP for sanctions; and (iv) the secretariat of the CCAMIP for other on-going supervision. There is concern that this system might operate slowly and therefore handicap efficient supervision.

68. The supervisory authority lacks powers to issue rules by administrative means. This power belongs exclusively to the MINEFI and should be deferred to the CCAMIP, as is already the case in some other countries. 
69. The insurance industry, itself, is involved in the supervisory functions of the CEA. This can be a source of conflict of interest and may impair the functioning not only of this body but of the overall supervisory framework.

\section{Means of supervisory agency}

70. The number of staff has to be increased. The CCAMIP has staff of very high quality and motivation, but effective operational supervision is not possible with only 50 commissaires-controleurs, because the number of supervised companies has increased enormously as a result of the merger of the CCA and the CCMIP. Staff recruitment should be eased by the recent financial autonomy provided to the CCAMIP by the Financial Security Law. Furthermore, the Financial Security Law strengthens insurance supervision and provides more responsibility for the supervisor. Finally, the CCAMIP aims to intensify on-site inspections so that each company is inspected at least every three to five years.

\section{Awaiting transposition of $E \boldsymbol{U}$ directives}

71. At present, regulation on financial conglomerates is incomplete, as the supervisory authority lacks the power to intervene if necessary. However, the relevant EU Directive will be transposed into French law before January 1, 2005.

72. The supervisor lacks powers to supervise insurance intermediaries (e.g., brokers and independent agents), ongoing supervision of which is currently scant. The situation will change shortly with the transposition of the EU Intermediary Directive (deadline at the start of 2005).

\section{$A M L / C F T$}

73. With respect to anti-money laundering/combating the financing of terrorism (AML/CFT), while significant steps have been taken by the authorities, there remain some gaps in the regulation and supervision in the insurance industry. The main issues are as follows: (i) the absence of consideration of AML/CFT internal controls when issuing business authorizations; (ii) the generally low rate of on-site examinations of insurance companies and the urgent need for a substantial increase in supervisory personnel; (iii) the absence of effective supervision of intermediaries, including appropriate sanctioning powers (although remedial measures will soon be introduced), and (iv) the absence of enforceable guidelines and of specific Customer Due Diligence (CDD) requirements for the handling of higher risk customers. 
Table 2. Recommended Action Plan to Improve Observance of IAIS Insurance Core Principles

\begin{tabular}{|c|c|}
\hline Reference Principle & Recommended Action \\
\hline $\begin{array}{l}\text { Supervisory authority } \\
\text { CP } 3\end{array}$ & $\begin{array}{l}\text { Give the supervisory authority power to issue regulations. } \\
\text { Increase staff of the supervisory authority. } \\
\text { Monitor the effectiveness and efficiency of the new organization, } \\
\text { setting a date for reviewing the structure. } \\
\text { Eliminate the participation of the industry in the supervisory decision- } \\
\text { making process. }\end{array}$ \\
\hline $\begin{array}{l}\text { Suitability of persons } \\
\text { CP } 7\end{array}$ & $\begin{array}{l}\text { Introduce a requirement that an insurance company must inform the } \\
\text { supervisory authority if it becomes aware of circumstances that may } \\
\text { lead to doubts about the fitness and propriety of owners, senior } \\
\text { management, and others in positions of responsibility. }\end{array}$ \\
\hline $\begin{array}{l}\text { Corporate governance } \\
\text { CP } 9\end{array}$ & $\begin{array}{l}\text { Empower the CCAMIP to issue and enforce a Code of Conduct of } \\
\text { Corporate Governance for all supervised insurance companies. }\end{array}$ \\
\hline $\begin{array}{l}\text { Internal control } \\
\text { CP } 10\end{array}$ & $\begin{array}{l}\text { Empower the CCAMIP to issue and enforce a Code of Conduct } \\
\text { containing the requirements for effective internal control for all } \\
\text { supervised insurance companies. This code could be combined with } \\
\text { the code dealing with the requirements of corporate governance. }\end{array}$ \\
\hline $\begin{array}{l}\text { Group-wide supervision } \\
\text { CP } 17\end{array}$ & $\begin{array}{l}\text { Issue a regulation regarding the group-wide supervision of financial } \\
\text { conglomerates headed by insurance companies (transposition of the } \\
\text { EU Directive on financial conglomerates). }\end{array}$ \\
\hline $\begin{array}{l}\text { Risk assessment and management } \\
\text { CP } 18\end{array}$ & $\begin{array}{l}\text { Require by law that all insurance companies establish risk } \\
\text { management systems which cover all material risks of an insurance } \\
\text { company. }\end{array}$ \\
\hline $\begin{array}{l}\text { Intermediaries } \\
\text { CP } 24\end{array}$ & $\begin{array}{l}\text { Empower the CCAMIP to supervise intermediaries. Require that all } \\
\text { agents and brokers be registered. }\end{array}$ \\
\hline $\begin{array}{l}\text { Anti-money laundering } \\
\text { CP } 28\end{array}$ & $\begin{array}{l}\text { Increase supervisory staff and raise AML/CFT on-site inspections of } \\
\text { insurance companies. Regulate and supervise, with appropriate } \\
\text { enforcement powers, intermediaries for AML/CFT activities. Consider } \\
\text { adequacy of internal AML/CFT controls when issuing business } \\
\text { authorizations. Issue enforceable guidelines for insurance companies } \\
\text { and extend these to intermediaries Promptly enact draft legislative } \\
\text { amendments to comply with FATF } 40 \text { Recommendations. }\end{array}$ \\
\hline
\end{tabular}

\section{Authorities' response}

74. The French Ministry of Finances appreciates the IMF overall assessment that the French insurance sector is financially sound, as verified by the comprehensive stress tests carried out commonly by the IMF and the French supervisory authority. 


\section{Supervisory authority}

75. As underlined in this report, the IMF mission took place during a period of transition. Since the publication of several decrees in July, however, this transitional period has ended and the new insurance supervisory environment is now fully in place. In particular, the CCAMIP has been inaugurated and authorized to levy a specific tax, in order to ensure its financial autonomy. This financial independence should enable the CCAMIP to increase staff. The CCAMIP has already adopted its budget and its code of conduct, and it has immediately followed up on the CCA and the CCMIP's supervision issues. It stands ready to take its first decisions.

76. The French insurance supervisory and regulatory framework, implemented by the Financial Security Law, is similar to the banking one. It distinguishes on the one hand the Treasury, which sets out the legal framework for insurance supervision, and on the other hand the CCAMIP, which implements it.

77. In addition, the Financial Security Law enables both the CCAMIP and the banking supervisory authority (Commission Bancaire) to participate in the law making process. Both authorities are indeed members of the newly created financial regulation advisory council, which issues an opinion before any law or decree is passed.

78. In order to respect the rules set by the European Court on Human Rights, the internal organization of the CCAMIP makes sure that people who have participated in preliminary investigations do not participate in decision-making processes regarding the controlled company: these decisions are taken by a college, which is part of the CCAMIP, whereas the controlling teams belong to the secretariat of the same CCAMIP. However, the CCAMIP constitutes one single legal administrative body. The former supervisory had the same internal procedures, which have proved to be efficient and to be at the same time a real guarantee against partial decisions.

79. To ensure the good quality of decisions on licensing and related issues, while avoiding conflict of interest, the law allows the participation of retired professionals to the decisions of the competent authority, which is the Comite des Entreprises d'Assurance. Moreover, the regulation clearly indicates that all information discussed among CEA members should be kept secret.

\section{Internal controls and risk management}

80. The insurance code currently requires insurances companies' boards to examine each year a comprehensive report on asset management, with detailed information on the measurement, evaluation and control methods, internal procedures and systems in place, the structure of asset portfolios, use and follow up of financial instruments. This comprehensive report is also sent to the CCAMIP. Companies also have to provide the CCAMIP with a report on reinsurance policy. The financial conglomerates directive, which is in process of implementation, requires insurance groups to establish appropriate internal controls and risk management procedures and strategies, in order to identify and measure all important risks 
and, therefore, to ensure capital adequacy and avoid risk concentration within a financial conglomerate.

81. To enforce these requirements and make sure that internal controls and risk management are effective and efficient, the Insurance Code provides the CCAMIP with several means of action, which can be used in case of serious shortcomings.

\section{$A M L / C F T$}

82. The CEA is considering regulatory measures, so that the quality of insurers' AML/CFT internal controls be considered when licensing insurance companies.

83. The financial autonomy of the CCAMIP should facilitate staff recruitment, which is necessary to reinforce AML/CFT controls, and higher the rate of on-site controls. Until now, the CCA has focused on life companies as it is stressed in the principle.

84. As far as the supervision of brokers is concerned, it should be noted that the Financial Security Law authorized the supervisory authority to impose sanctions on brokers. Moreover, the directive on insurance intermediates, which should be implemented in France very soon, creates a national registry of all intermediates, complies them to have a financial guarantee and a professional civil responsibility insurance police, centralizes the control on fit and proper conditions, and enables the CCAMIP to withdraw a broker's registration on grounds of regulation infringement.

85. The CCA has issued recommendations in June 2001 that have been passed to the mission and that are available on the website: www.cca.gouv.fr. This document is currently under review to be updated.

86. Lastly, a European directive is currently under preparation to comply with the revised FATF 40 Recommendations and should be adopted by the EU before summer 2005.

\section{IOSCO ObJeCtives ANd Principles of Securities Regulation}

\section{General}

87. This assessment evaluates implementation by the French authorities responsible for the regulation and supervision of securities markets and intermediaries of the IOSCO Objectives and Principles of Securities Regulation. The assessment was conducted, on- and off-site, during the first half of 2004 in accordance with the 2003 version of the IOSCO Objectives and Principles of Securities Regulation and the IOSCO Assessment Methodology adopted in October 2003. Reference was also made to the CPSS/IOSCO Recommendations on Securities Settlement Systems and the consultative draft of the Recommendations for Central Counterparties, together with relevant IOSCO reports and IMF guidance. 
88. The assessment covers two broad areas: (i) the securities regulatory framework in France as simplified, enhanced and modernized by the Loi de Sécurité financière (Financial Security Law) $N^{o}$. 2003-706 of August 1, 2003 and Decree No 2003-1109 of November 21, 2003, relating to the Autorité des Marchés Financiers (AMF); and (ii) the powers, capabilities, and responsibilities of the competent French authorities, as compiled in the Code Monétaire et Financier (Monetary and Financial Code). The Financial Security Law creates the AMF, the new primary securities regulator for both securities and derivatives, which merges the Commission des Opérations de Bourse (COB), the Conseil des Marchés Financiers (CMF) and the Conseil de discipline de la gestion financière (CDGF).

\section{Information used in the assessment}

89. This assessment is based on various self-assessment documents provided by the AMF, including the draft answer prepared by AMF, to the IOSCO Methodology for Assessing the Implementation of the IOSCO Objectives and Principles of Securities Regulation. The assessment was also the result of (i) meetings with the Ministry of Economy, Finance and Industry (MINEFI); (ii) interviews with senior staff of the AMF responsible for each of the functional areas addressed by the Principles and the Chairman and Secretary General; (iii) sessions with staff of the Commission Bancaire (CB), the Comite des Établissements de Crédit et des Entreprises d'Investissement (CECEI), the Banque de France (BdF) (with respect to their respective roles in the securities framework), and the Agence des Participations de l'État (APE) (in connection with market structure); (iv) discussions with Euronext NV (Paris operations) (re: cash and derivatives markets), Euroclear (re: payments and settlement), LCH-Clearnet SA (re: clearing); (v) meetings with selected asset management and investment firms (and the related professional associations) representing different scales and complexity of financial services activity; (vi) selective review of the websites of the foregoing, annual reports, the Monetary and Financial Code, existing regulations and published guidance, instructions, recommendations, and statistics on operations; (vii) evaluation of the systems for publishing information on issuers, the combined data base composing the registry of licensing information, the official mechanisms for publication of regulatory actions; (viii) exchange operational oversight and regulatory surveillance systems; and finally (ix) the responses of the AMF and other authorities to multiple inquiries on matters of nuance and detail.

90. The assessors benefited from the full cooperation of the French authorities and received all necessary information. Although the Financial Security Law builds substantially on the old law and framework, which has been in place and effective for many years, there remain areas where the authorities are in the process of determining how best to fully implement the enhanced powers and new structures in the new law.

\section{Capital market and structural overview}

91. Capital markets in France are large and well developed, with a range of equity, debt, derivatives, and mutual fund products available to investors. Of French households' 2002 
savings flows, about 48 percent went into investments in securities and mutual funds, ${ }^{17}$ 38 percent into life insurance products and 15 percent into savings accounts. ${ }^{18}$

92. Mutual funds, of various types including Undertakings for the Collective Investment of Transferable Securities (UCITS), are an important investment vehicle in France. Among industrialized countries, only the United States has a larger mutual fund asset to GDP ratio (68 percent) than France (64 percent) in 2003. A large proportion of the mutual fund products held by investors are created and sold for the account of life insurance firms. The reason for this is that there are substantial tax benefits to households holding life insurance savings products, including those that are in the form of mutual funds.

93. The financial sector as a whole is dominated by universal banks - in large part by the six major domestic banking groups. There are 90 French-licensed investment/broker firms, 346 commercial banks (1,011 credit institutions) and approximately 500 asset management firms. The largest domestic broker/dealers (i.e., investment firms) are part of the six large banking groups. Also, an important portion of the assets under management in France (41.5 percent of the total) is managed by the asset management companies of the six largest banks.

94. France's only stock exchange, Euronext Paris, which is a subsidiary of Euronext NV, operates a fully electronic equity exchange. In terms of stock market capitalization, France ranks fourth in the world after the United States, the United Kingdom, and Japan, with a market capitalization of 73 percent of GDP or EUR 877.7 billion as of end-2003.

95. Euronext Paris was formed as a result of the consolidation of several European stock markets that took place in 2000. The stock exchanges in Paris, Amsterdam, Brussels and, a little later on, Lisbon (and Porto, Portugal) joined forces under the Netherlands holding company Euronext NV, a demutualized, public company whose shares are listed on the primary market (Premier Marché) of Euronext Paris. The shareholders of the underlying national markets received shares in the new company in exchange for their original holdings. For regulatory oversight and other legal reasons, Euronext NVs exchange subsidiaries are licensed locally in each participating country. Maintaining the local exchange permits issuers, intermediaries and investors in each country to access a common platform through the local portal with which they are most familiar. Membership in one market permits access to all issues traded on the common platform. The maintenance of a single quote and a common cross-border order book for the listed securities emanating from each jurisdiction creates a broader liquidity pool and greater transparency for each local market. The principal portal for equities is Paris, for equity options Amsterdam, and for financial derivatives London.

${ }^{17}$ Negotiable debt securities, bonds, shares and equity, mutual funds shares, and claims on insurance companies.

${ }^{18}$ Currency and deposits (banknotes and coins, transferable deposits, contractual savings). 
96. The internal market structure of Euronext Paris remains as it was in the Bourse de Paris, with three segments: the primary market (Premier Marché), the secondary market (Second Marché), and the new market (Nouveau Marché). Euronext also offers companies the option to trade its overlapping NextPrime and NextEconomy market segments.

97. Similarly, there is a single clearing system, LCH-Clearnet SA, and a single settlement system, Euroclear France, for all equity securities traded on Euronext markets. As the local exchanges are not merged, the clearing interface continues to be regulated through the respective local authorities. For Euronext Paris, this means that it is largely overseen by the AMF. The cross-jurisdictional nature of Euronext Paris, LCH-Clearnet SA, and Euroclear France has led to the implementation by the French authorities of innovative cooperative cross-border arrangements with the authorities in the other jurisdictions in which these firms are active.

98. The annual transaction value in equities (counted on one side) was EUR 877.7 billion in 2003, with an average daily turnover of EUR 3.442 billion. The number of trades was 101 million, with an average daily turnover of $396,287 .{ }^{19}$ The five most actively traded shares in 2003 accounted for 30 percent of turnover. In 2002, the nine most actively traded shares accounted for 30 percent of the total number of trades. According to BdF statistics, equities listed in France are primarily traded by institutions and foreign investors.

99. The exchange traded futures and options markets in Paris (MATIF and MONEP respectively) are now also part of Euronext. The Paris derivatives markets have been integrated into the Euronext-liffe trading structure and are cleared by LCH-Clearnet, Ltd. The derivatives traded in Paris are regulated by the French authorities. The CAC 40 is the most active Paris-based derivatives contract.

100. There is also Powernext, a commercial energy exchange owned by Euronext in which non-intermediated trading occurs. Additionally, the Marché Libre is an unregulated (OTC) equity market, in which 258 issues are traded.

101. The current structure of the government bond market includes long-term debt instruments (7- to 30-year initial maturities; OATs, OATis, OAT€is and TEC10 OATs), medium-term debt instruments ( 2 and 5 year initial maturities; BTANs) and short-term debt instruments (1 year or less; BTFs). OATs comprise 65 percent of the marketable government debt outstanding, BTANs 20 percent, and BTFs the remainder. Inflation-linked OAT issuances have grown, particularly with the recent introduction of European inflation-linked bonds (OAT€is) in 2001. Inflation-linked bonds now comprise about 10 percent (€44.5 billion) of the outstanding stock of OATs (or 8 percent of total outstanding government debt instruments). The main investors are insurance companies, international pension funds, asset managers and alternative traders.

${ }^{19}$ These figures reflect all domestic and foreign shares traded on Euronext Paris. 
102. The nonfinancial corporate bond market in France has grown substantially with the introduction of the euro. At the end of 1998, the corporate bond market comprised 12 percent of outstanding French bonds, while it currently stands at 22 percent.

103. Interdealer trading for the French government bond market, and to a lesser extent the nongovernment bond market, has almost completely migrated to the MTS electronic trading platform.

\section{Regulatory structure and practices}

104. The changes in the Financial Security Law concentrate all regulatory powers in an independent regulator. This new structure reflects the devolution of market oversight from a shared supervisory activity between a professional body, Conseil des Marchés Financiers (CMF), a successor to the Conseil des Marchés à Terme (CMT), and an independent administrative authority, the COB, effected in 1996 by the Financial Modernization Act (Loi MAF) to today's new model where AMF is the principal securities regulator.

105. The AMF is an independent public authority with a separate legal identity and "taxing" authority, comprised of a 16-member board (college), chaired by a full-time chairman and a separate 12-member Commission des Sanctions. It also has five consultative commissions, each with its own chairman and vice chairman, relating to implementation of the new investment services and market abuse directives, clearing and settlement, collective investments, application of the transparency directive, and minority shareholders and savings. The board members, like members of a typical business board, may engage in other professional activities in addition to their service on the college. There is no cross membership between the Commission des Sanctions and the board other than the representative of the ministry.

106. The AMF is accountable to the government through oversight of its budget, the role of the minister with respect to the adoption of regulations, and the review process with respect to the regulatory actions or sanctions it takes. The AMF has broad sanctioning powers which must be exercised through its separately constituted Commission des Sanctions. All members and staff are subject to confidentiality and professional conduct requirements as a matter of law. The $\mathrm{CB}$ also has the power to take prompt corrective action and certain sanctioning powers that can be applied to enforce its prudential oversight of investment services providers that are not subject to the sole competence of the AMF.

107. The AMF licenses and prudentially supervises operators of publicly offered collective investment schemes, and portfolio (asset) managers for third parties; regulates the public offer and reporting of financial information with respect to issues, and marketing generally, and also the flow of information relative to takeover bids. The AMF also has responsibility for market undertakings, depositories for securities and assets of collective investment schemes, and clearing and settlement systems and their related custodians, without prejudice to the functions of the $\mathrm{BdF}$ and its specific role with respect to payments. 
108. Licensing (except for insurance companies engaging in insurance activities) is committed to the CECEI (i) in consultation with the AMF in the case of credit institutions and investment services providers engaged in investment services, pure custodians and clearing members; and (ii) with approval of the program of operation, if authorization for asset management activities is sought by such firms. Prudential oversight, including oversight over members of markets, clearing organizations and custodians, but not including insurance companies acting in the capacity of insurance companies, is the responsibility of the CB. The Financial Security Law therefore retains a modified "twin-peaks" structure for financial regulation.

109. The BdF commits staff to the licensing and prudential supervision, and provides leadership through its Governor's participation as Chair of both the CB and the CECEI (articles 613-3 and 612-3 of the Monetary and Financial Code). The BdF also has competence over payment system functions and, as a consequence, certain aspects of securities settlement. And, in the case of markets, while regulated markets are the responsibility of the AMF, the $\mathrm{CB}$ is expected to oversee any Automated Trading Systems (ATS), which are viewed as intermediaries, and has other powers related to Euronext being a credit institution.

110. Coordination with the prudential authorities and the AMF is organized, in the case of day-to-day operations, through interstaff contacts, information sharing, certain combined databases, and regular monthly meetings. In the case of general policy and matters of particular cross-market or common interest, such coordination is accomplished through an inter-institutional, statutorily-prescribed board composed of the heads of the financial services agencies (Collège des autorités de contrôle des entreprises du secteur financier), which must meet at least three times a year, and is presided over by the Minister in charge of the Economy, Finance and Industry or his representative. Cross membership of the regulatory/supervisory authorities also fosters cooperation, for example, by the statutory participation of the AMF Chair as a participant on the Board of the CECEI and participation of the Governor of the BdF on the AMF Board.

111. In general, the exchanges and clearing and settlement organizations control/monitor their operations through rules adopted subject to review of the competent authority and those rules (and any powers or actions with respect to their infringement) are regarded as founded in contract and not in public law. In the case of regulated markets and related clearing arrangements, the AMF may delegate (license specified individuals to perform) certain compliance activities as to their members, including with respect to the transmission of orders by financial services providers.

112. There also exist protocols among the national regulators and markets within the Euronext, NV group, and the related clearing and settlement institutions in the various jurisdictions which comprise Euronext, Euroclear and LCH-Clearnet that apply to how those institutions are operated and supervised. In this respect, Euronext France and LCH-Clearnet, Ltd., the British-based holding company for the clearing organization as well as LCHClearnet SA are each credit institutions with consequent implications for how supervision 
and regulation of these entities is organized - that is, the $\mathrm{CB}$ and the $\mathrm{BdF}$ as well as the AMF have specific responsibilities.

\section{General preconditions for effective securities regulation}

113. In general, the preconditions for an effective regulatory framework for capital markets and the provision of financial services assume (i) the existence of a legal framework that supports the integrity of contract and property rights and recognizes the instruments traded in the market as well as the rules that facilitate their trading; (ii) a commercial and insolvency regime that facilitates the taking of collateral, the use of clearing services, and the enforcement of guarantees; (iii) sound company law that protects direct investors; (iv) laws which support the ability to identify and protect client assets; (v) reliable and consistent accounting standards; and (vi) the confidence of the marketplace that the rules will be consistently and equitably enforced and that the rules of the marketplace can be applied notwithstanding the bankruptcy of particular market participants. These conditions are premised on the assumption that the judicial, administrative, and regulatory authorities will reliably honor and equitably apply the rule of law. Certainty as to the application of the law, and confidence in its equity, is fundamental to the reliable functioning of markets and market confidence. There is no evidence that these preconditions are not met in France.

114. As for the openness of its markets, the market regulators in France historically have been open to cross-border arrangements within the European Union - and beyond - and they have been creative in facilitating these arrangements by putting in place the regulatory and legal supports necessary for their functioning. In particular, they indicated support for maximizing the use of the Lamfalussy process, which aims at better harmonizing the national approaches among various jurisdictions within the single European market, specifically by broadening the use of the mechanisms for regulatory development and consultation through the Committee of European Securities Regulators (CESR). ${ }^{20}$

\section{Main findings}

115. The standard of securities regulation in France is very high. However, some refinements are recommended.

116. Principles Relating to the Regulator (1-5). The predecessors to the AMF have in the last 20 years made great strides in implementing effective financial regulation and have been leaders within Europe. In the Financial Security Law, the powers of the competent authorities charged with securities regulation have been further expanded, modernized, and simplified to reflect the need to meet international standards and European requirements and to assure that the $\mathrm{AMF}$, the $\mathrm{CB}$ and the CECEI can allocate their respective resources most efficiently. Provisions for an internal audit facility and for all guidance to be accomplished through General Regulations also enhance the accountability of the AMF. The other

${ }^{20}$ There are now CESR-like arrangements for insurance and banking as well. 
authorities are subject to similar requirements. The AMF is in the process of combining and streamlining existing guidance and assuring it has sufficient human resources to exercise its new powers especially with respect to inspections and oversight of miss-selling (i.e., the use of improper sales practices or marketing) through the banking network.

117. The modified twin peaks structure in France is intended to permit the competent authorities to focus contemporaneously on high priority customer protection and prudential issues and thereby to address both stability and enforcement issues effectively. ${ }^{21}$ At the same time, the ability of the system to respond to general and specific problems in the market and to assure effective supervision of financial services providers subject to separate conduct of business and prudential supervision depends on effective and consistent cooperation among authorities with different functional competences on a day-to-day basis and in the event of a crisis. Although there is strong evidence of effective cooperation among the authorities, such cooperation is only explicitly required for licensing and for high-level policy matters.

118. With respect to independence, there is concern that the enforcement effectiveness of the Commission des Sanctions might be adversely affected to the extent that presence of the Ministry's representative could be perceived to have a chilling effect on deliberations or the outcome of specific cases, even if in practice this is not the case. Maintaining as transparent as possible procedures with respect to the ministry's representation may help mitigate any such perception. The assessor defers to the assessment of the structure of the CB and the CECEI with respect to assessment of compliance of the French system with the Basel Core Principles.

119. Principles Relating to Self Regulation (6-7). Since the French system does not make use of self-regulatory authorities, these principles are inapplicable.

120. Principles Relating to Enforcement of Securities Regulation (8-10). The AMF has comprehensive enforcement powers, including investigative, administrative and criminal referral powers, plus the right to make submissions in writing with respect to matters heard within the judicial system. In the first few months of operations, the AMF has, through its Commission des Sanctions, heard four substantial administrative cases and imposed penalties for violations of various portions of the law. Nonetheless, the execution of the AMF's enforcement powers should be kept under review, both with respect to the treatment and timeliness of cases potentially subject to both civil and criminal penalties, the functioning of the Commission des Sanctions and the ability of the AMF to present evidence in administrative proceedings generated as the result of its monitoring and on-site inspection activity. Obtaining the capacity to settle cases and to obtain restitution administratively might also be explored. The $\mathrm{CB}$ also has powers to achieve compliance with prudential

${ }^{21}$ The assessor finds that France has designed a structure which should meet its specified objectives for a fair and efficient execution of its regulatory responsibilities in both the prudential and conduct of business area, but neither the assessor nor IOSCO suggests that alternative structures would not be equally effective. 
requirements and to sanction noncompliance and, in fact, the AMF cooperates with the $\mathrm{CB}$ in connection with the inspection of regulated entities that provide investment services.

121. Principles for Cooperation in Regulation (11-13). The AMF has a state-of-the-art capacity to cooperate domestically and with its foreign counterparts, and is a signatory of the IOSCO Multilateral Memorandum of Understanding, which requires a comprehensive peer review of the law supporting each signatory's power to engage in the cooperative efforts specified therein. Ideally, however, the AMF should be able to obtain information requested by its foreign counterparts that pertains to competences within the remit of other domestic authorities with securities-related functions. This is because many jurisdictions provide for the securities regulator to have both prudential and conduct-of-business competences. In addition, many jurisdictions would not expect the appropriate counterparty with respect to regulation of an ATS, or market analogue, to be the prudential regulator. This being said, the Financial Security Law permits the other regulatory authorities involved in securities oversight also to provide cooperative assistance to foreign authorities directly.

122. Principles for Issuers (14-16). In France, the law affecting issuers is a complex combination of financial services legislation and company law. In general, the disclosure required of public companies meets international standards. The AMF has substantial authority to regulate the information provided in connection with the operation and marketing of public companies and in connection with takeover bids. Prospectuses of public companies must receive approval (a visa or agreement in the case of Collective Investment Schemes-CIS) from the AMF. Such prospectuses and related continuing information are readily available on the AMF website through a facility known as the DIF or Décisions et informations financières, or in the case of CIS, GECO (Gestion collective).

123. The AMF is in the process of improving the timely availability to the investing public of information with respect to insider transactions in securities and enhancing protections available to minority shareholders generally. The AMF has played a leadership role in the movement toward adoption of international financial reporting standards and in the development of robust auditor oversight arrangements. It is important that the securities regulatory authority continue to have active input into the audit standard setting and oversight process.

124. Principles for Collective Investment Schemes (17-20). France has a large, vibrant and sophisticated market for CIS of several types. The AMF's new powers with respect to the oversight of depositories and with respect to financial advisers are in the process of being implemented, and resource requirements relative to such implementation are being assessed. The licensing of schemes and asset managers meets international standards as does the level of information provided to participants on an ongoing basis. Although conduct of business requirements are fully within the power of the AMF, further oversight of marketing requirements and the capacity to address miss-selling (currently based essentially upon complaints) would enhance oversight of the bank distribution network. The AMF is in the process of enhancing its CIS program generally and plans to review redemption practices and on-site inspection capabilities in the process. In the interim, the AMF has been proactive in 
addressing issues that have arisen in the market at large with respect to the regulation of CIS. In particular, it has taken steps to determine where it is likely that potentially improper late trading and/or market timing practices have taken place and to schedule on-site investigations of at-risk entities. It has also provided guidance on the valuation of products that do not have a reliable market price and required third party valuation of mark-to-model systems of valuation.

125. Principles for Market Intermediaries (21-24). Licensing, including fitness and capital requirements for French intermediaries are conservative and are overseen, except in the case of asset management companies, by the relevant banking authorities. Licensing requirements have been expanded to include employees and or agents of licensed intermediaries who solicit new customers directly under the auspices but outside the premises of licensed intermediaries. Information on compliance is shared between the regulators and the record of managing financial problems has been good. There are provisions for addressing large exposures and for winding down firms that experience financial deterioration. Required internal controls are specified and firms are required to have mechanisms in place to comply with applicable law, although internal audit requirements have not been extended to asset managers. Conduct of business requirements and provisions for assuring that investment services providers know their customers, consider the suitability of transactions when recommending investments to customers, and avoid conflicts of interest are contained in the Financial Security Law itself and may be implemented by the AMF within the General Regulations. This assessment recommends assuring continued cooperation between the competent authorities in executing their respective responsibilities for intermediaries.

126. The permission for retail customers to trade, without settling except on a net basis, deferred settlement contracts also raises some concerns. Permission for a 30-day settlement against the broker for transactions undertaken in the market in highly liquid securities puts a premium on the adequacy of margin collected by the broker and on adequate management of the amount of exposure undertaken. From a supervisory perspective, this practice raises a need for timely and accurate information on broker exposures vis-à-vis their customers and on customer exposures across multiple brokers. The current frequency of reporting and monitoring by the $\mathrm{CB}$ may not be sufficient to assure that a firm experiencing difficulties with these transactions would be identified prior to more serious financial exposures being incurred. As this is retail activity, there also may be conduct of business issues that need to be addressed.

127. Principles for Secondary Markets (25-29). The securities markets in France are subject to a well-developed regime for authorization and oversight by both the AMF and other authorities with regulatory competence over the exchanges that participate on the common platform of Euronext. With respect to ATS there is no very defined approach, and currently such systems, to the extent they exist, are subject to supervision by the CB. The $\mathrm{AMF}$, in cooperation with the supervisors of the other markets integrated therein, has regulatory authority over Euronext within the French system (in preference to substantial reliance on the exchange itself). This permits intensified oversight of this demutualized and 
self-listed market. AMF can, and does, license certain personnel on site at the exchange to perform compliance and/or investigative work and the exchange continues to be responsible to enforce its rules under private law. Euronext is also a credit institution and subject to relevant oversight as such.

128. The markets are subject to stringent transparency requirements. There is the authority to relax certain of these in the future, consistent with an EU-wide trend. The AMF should keep under review whether any new regime maintains appropriate transparency levels for investors participating on the markets.

129. The COB and CMF have long had authority with respect to market abuses. The expanded authority that the Financial Security Law has granted the AMF to address insider dealing, as well as manipulation and dissemination of false information by any person at the administrative level, is to be commended. The AMF should keep under review how the interplay between criminal and civil authority affects the prosecution of market abuse cases.

130. The AMF and related authorities have the capacity to address concentrations at firms and in the markets and to transfer positions, wind down firms or halt trading as necessary to contain risks to the system. They should assure that there is adequate communication between the market and separate clearing agencies and that the very innovative arrangements that are in place to oversee the many linked markets of Euronext operate well not only on a day-to-day basis but also in crisis circumstances.

131. Principle 30. Clearing and settlement arrangements were assessed in accordance with the CPSS/IOSCO Recommendations for Securities Settlement Systems and the consultative draft of the Recommendations for Central Counterparties. As a consequence, Principle 30 was not assessed and such arrangements were only considered in connection with the securities sector assessment in so far as clearing and settlement support effective operation of France's secondary markets. 
Table 3. Recommended Actions to Improve Implementation of the IOSCO Objectives and Principles of Securities Regulation

The AMF, together with the other agencies responsible for securities regulation in France administer a regulatory framework that clearly has been designed with international standards well in mind. The following are some general suggestions to continue pursuing planned improvements and encouragement to make the innovative and well-designed cooperative arrangements for surveillance of its cross-border markets effective.

\begin{tabular}{|c|c|}
\hline Reference Principle & Recommended Action \\
\hline \multirow[t]{3}{*}{$\begin{array}{l}\text { Principles Relating to the } \\
\text { Regulator } \\
\text { (Principles 1-5) }\end{array}$} & $\begin{array}{l}\text { With respect to Principle 1, the current wording of the Act does not } \\
\text { specifically require the sharing of information between the CB and the } \\
\text { AMF. Information is in fact being shared, but the CB and the AMF } \\
\text { should explore whether additional arrangements could enhance the } \\
\text { timeliness and certainty that information with respect to prudential } \\
\text { matters that is important to oversight of conduct of business and vice } \\
\text { versa is shared as needed. In particular, the limitation of the function of } \\
\text { the AMF to conduct of business issues should not prevent it from } \\
\text { receiving prudential information as relevant to its oversight of conduct } \\
\text { of business or as necessary to its securities counterparts in other } \\
\text { jurisdictions engaged in investigations of securities or futures } \\
\text { misconduct. }\end{array}$ \\
\hline & $\begin{array}{l}\text { With respect to Principle 2, independence, the actual effectiveness of } \\
\text { the arrangements for protecting the independence of the AMF, in } \\
\text { particular the Commission des Sanctions should be kept under review, } \\
\text { to assure that the presence of the Ministry does not permit political } \\
\text { considerations to affect decisions on individual cases, or for there to be } \\
\text { the perception that they could do so. }\end{array}$ \\
\hline & $\begin{array}{l}\text { As to Principle 3, the AMF should continue to assess how best to } \\
\text { deploy its resources between off-site and on-site oversight and to } \\
\text { assure human resources are sufficient to address review of prospectuses } \\
\text { and to support expanded monitoring powers. }\end{array}$ \\
\hline $\begin{array}{l}\text { Principles of Self-Regulation } \\
\text { (Principles 6-7) }\end{array}$ & Not applicable. \\
\hline $\begin{array}{l}\text { Principles for the Enforcement of } \\
\text { Securities Regulation } \\
\text { (Principles 8-10) }\end{array}$ & $\begin{array}{l}\text { The timeliness of proceedings using enforcement and investigative } \\
\text { powers, and the effect of the overall program, should be evaluated after } \\
\text { the new organizational structure has had some time to function. The } \\
\text { AMF should aggressively pursue overturning any judiciary } \\
\text { interpretations of the doctrine of impartiality that could undermine its } \\
\text { capacity to exercise its monitoring and enforcement functions } \\
\text { effectively. In regard to Principle 10, the AMF should continue its } \\
\text { policy of being as transparent as possible with respect to sanctions. }\end{array}$ \\
\hline & $\begin{array}{l}\text { Development of readily understandable public statistics to demonstrate } \\
\text { enforcement and investigatory performance also would be useful. }\end{array}$ \\
\hline
\end{tabular}




\begin{tabular}{|c|c|}
\hline Reference Principle & Recommended Action \\
\hline $\begin{array}{l}\text { Principles for Cooperation in } \\
\text { Regulation } \\
\text { (Principles 11-13) }\end{array}$ & $\begin{array}{l}\text { As to Principle 13, the assessor believes that the ideal channel for } \\
\text { exchange of information and the delivery of assistance to foreign } \\
\text { securities regulators is through the securities regulatory authority, } \\
\text { although direct arrangements should not be prohibited. For example, } \\
\text { information on the relationships within groups should be available to a } \\
\text { requesting individual securities regulator through the AMF. }\end{array}$ \\
\hline $\begin{array}{l}\text { Principles for Issuers } \\
\text { (Principles 14-16) }\end{array}$ & $\begin{array}{l}\text { As to Principle 15, the AMF should consider a materiality standard for } \\
\text { immediate disclosure to the public of transactions by large shareholders } \\
\text { and management insiders. Further work on minority shareholder rights } \\
\text { should be encouraged. Issues of concern that emerge from experience } \\
\text { of oversight operations of the AMF should be referred to the } \\
\text { consultative commission in its considerations. As to Principle 16, the } \\
\text { AMF should assist in the development of robust oversight of auditors } \\
\text { and auditing standards and the new Haut Conseil du Commissariat aux } \\
\text { Comptes (High Council for Auditorship) should take adequate account } \\
\text { of the views of the AMF. }\end{array}$ \\
\hline $\begin{array}{l}\text { Principles for Collective } \\
\text { Investment Schemes } \\
\text { (Principles 17-20) }\end{array}$ & $\begin{array}{l}\text { As to Principle 17, the AMF should consider more robust guidance on } \\
\text { related party transactions in CIS. Regarding Principle 20, guidance } \\
\text { with respect to redemptions could be strengthened to specify what } \\
\text { circumstances for suspending redemptions are appropriate. }\end{array}$ \\
\hline $\begin{array}{l}\text { Principles for Market } \\
\text { Intermediaries } \\
\text { (Principles 21-24) }\end{array}$ & $\begin{array}{l}\text { As to Principle 21, the AMF and the CECEI should promptly use } \\
\text { existing powers to assure that needed licensing information is readily } \\
\text { available to the public. Regarding Principle 22, the CB and AMF } \\
\text { should assure that adequate provisions exist at brokers who use } \\
\text { deferred settlement positions (SRDs) and for oversight of broker capital } \\
\text { in such cases as to detect deteriorating capital situations promptly so } \\
\text { that corrective actions are possible without systemic impact or adverse } \\
\text { effects on customers. }\end{array}$ \\
\hline $\begin{array}{l}\text { Principles for the Secondary } \\
\text { Market } \\
\text { (Principles 25-30) }\end{array}$ & $\begin{array}{l}\text { The relevant authorities should assure that the innovative arrangements } \\
\text { for the oversight of cross-border clearing arrangements could be } \\
\text { effective in the case of a firm or a market disruption. }\end{array}$ \\
\hline
\end{tabular}

\section{Authorities' response}

132. The AMF contends that, within the French system, the AMF's structure has been designed explicitly to be as independent as possible. While the AMF disputes that its current institutional structure is in any way susceptible to political interference, the AMF understands that the issues raised with respect to structure are issues that could be of relevance to outside observers and indicates that it expects to continue its record of assuring that no improper interference in individual cases occurs.

133. The AMF also notes that its enforcement system, which the assessor has found to have appropriate powers and authorities and to have produced significant cases, is currently effective and that the processes for working with the Public Prosecutor with respect to offenses that are both criminal and civil, such as insider trading and market abuse, have proved effective to date. The AMF does not have a history of settlement procedures or a 
process for administrative restitution, which are not required as a matter of international standards, but which may constitute enhancements. The AMF has always kept its programs under review and may consider further enhancing its existing enforcement powers over time. Where the judiciary has potentially put certain powers into question, the AMF has acted aggressively to contest the adverse judicial interpretation.

134. Although the AMF has contested some characterizations of the regulatory structure with respect to independence and transparency, indicated that despite lack of an explicit requirement to cooperate, in all cases domestic regulators do so in fact, and provided substantial comments addressing the detail and fact of application of their regulatory framework, the AMF essentially does not disagree with the specific recommendations and indicates that most recommended areas of enhancement are currently underway or under consideration.

135. In particular, the AMF supports assuring human resources are sufficient, among other things, to execute its expanded powers with respect to depositories and having sufficient authority to effect the outcomes with respect to audit oversight of the Haut Conseil.

\section{RECOMMENDATIONS FOR SECURITIES SETTLEMENT SYSTEMS (RSSS)}

\section{General}

136. As part of the Financial Sector Assessment Program, an assessment of the observance of the infrastructure for clearing, settlement and custody of securities on the CPSS/IOSCO Recommendation for Securities Settlement Systems was conducted.

137. Prior to the mission, the Banque de France (BdF) made a thorough self-assessment of the two securities settlement systems of Euroclear France, which was used as basis for the assessment.

\section{Scope of the assessment}

138. The assessment covers Euroclear France as Central Securities Depository (CSD) for a broad range of securities, such as treasury bills, all other negotiable short-term instruments, public sector and corporate bonds and equities. Almost all securities in France (99.7 percent) are dematerialized in Euroclear France. The residual securities are immobilized in this CSD.

139. Euroclear France operates two systems for the settlement of the aforementioned securities:

(i) Relit+ ensures delivery versus payments on a gross-net basis (model 2 DvP). The multilateral net positions at the cash side are settled three times a day in Transferts Banque de France (TBF), the Real-Time Gross Settlement (RTGS) payment system operated by the 
BdF. LCH-Clearnet SA settles via Relit+ its positions vis-à-vis its counterparties stemming from the transactions on the stock exchange;

(ii) RGV2 irrevocable channel (further on called RGV2-TFT) clears all transactions on a trade for trade basis with intraday finality (model $1 \mathrm{DvP}$ ). The cash leg is settled on dedicated cash accounts opened with the BdF and is directly operated by Euroclear France. A so-called liquidity bridge enables participants to transfer cash between these dedicated cash accounts in RGV2 and their cash account held in TBF and vice versa to optimize liquidity management. RGV2-TFT is, among other things, used for the executions of monetary transactions and the collateralization of intraday credit operations.

\section{Institutional and market structure}

140. Capital markets in France are large and sophisticated. In terms of stock market capitalization (in dollar value terms) and debt securities market capitalization, France ranks fourth in the world and the value of all listed securities amounted slightly above 200 percent of GDP at end-2003.

141. The stock exchange in Paris has been managed by Euronext-Paris, which since September 2000 is a wholly owned subsidiary of Euronext NV, a holding company incorporated under Dutch law. Euronext is the result of a merger between the stock exchanges of Belgium, France and the Netherlands. However, to meet regulatory requirements, the stock exchanges in the different countries retained a separate identity. Euronext Holding also operates the stock exchange in Portugal (Euronext Lisbon) and, since the beginning of 2002, the international futures and options exchange in London (Euronext liffe).

142. Both securities and derivatives are traded on Euronext Paris platforms. In the secondary market for securities, total turnover amounted to EUR 905 billion in 2003, against EUR 1,045 billion in the previous year (average daily turnover in 2003 amounted to EUR 3.5 billion).

143. All stock exchange transactions are cleared via Clearnet, a central counterparty. Clearnet is the single clearinghouse of the Euronext group and clears transactions in Belgium, France, the Netherlands and Portugal; it also clears over-the-counter (OTC) transactions in different markets in France and abroad. At the beginning of 2004, an alliance was formed between Clearnet and London Clearing House and Clearnet was renamed LCHClearnet SA.

144. The settlement of the securities transactions on the French markets takes place via the securities settlement systems of Euroclear France. Euroclear France is fully owned by the Belgian Euroclear Bank, which also possesses CSDs in Belgium, the Netherlands and the U.K. 
145. The total value of all trades settled in Euroclear France's securities settlement systems amounted to EUR 52,996 billion in 2002.

\begin{tabular}{lrrrrrrr}
\hline Year & 1997 & 1998 & 1999 & 2000 & 2001 & 2002 & 2003 \\
\hline $\begin{array}{l}\text { Instructions } \\
\text { (millions) }\end{array}$ & 18 & 22 & 28 & 41 & 31 & 29 & 28 \\
$\begin{array}{l}\text { Value } \\
\text { (Euro billions) }\end{array}$ & 22,660 & 32,046 & 38,892 & 36,835 & 43,635 & 52,996 & 52,528 \\
\hline
\end{tabular}

\section{Description of regulatory structure and practices}

146. In France, the Autorité des Marchés Financiers (AMF) and the BdF are the competent authorities for the regulations and oversight of Securities Clearing and Settlement Systems (SCSS). According to article 621-7 of the Monetary and Financial Code, AMF specifies the general organizations and operational principles of securities settlement systems. It also has to approve the operating rules of these systems. Further on, AMF regulates the activities of custodians. Without any prejudice to the competencies of the AMF, the $\mathrm{BdF}$ is charged with the oversight of SCSS. There is a close cooperation between the $\mathrm{AMF}$ as securities regulator and the $\mathrm{BdF}$ as overseer. Representatives of the BdF have consultative roles on the Board of the AMF and in some committees and the activities with respect to the regulations and oversight of Securities Settlement Systems (SSS) are clearly coordinated.

147. Being a credit institution, LCH-Clearnet SA is not only supervised/overseen by AMF and $\mathrm{BdF}$ but also by the Commission Bancaire (CB).

148. The cross-jurisdictional nature of the Euronext group, LCH-Clearnet and the Euroclear group has led to the implementation of rather innovative cooperative cross border arrangements between the French authorities and the supervisors/ overseers in the other jurisdictions in which these firms are active. These arrangements for cooperative oversight/regulations for the individual institutions are codified in Memoranda of Understanding signed by all relevant authorities in the different countries.

\section{Information and methodology used for the assessment}

149. The assessment was based on the self-assessment conducted by the BdF using the CPSS/IOSCO assessment methodology for Recommendations for Securities Settlement Systems. Discussions were held with the BdF, the AMF, Euroclear France and market participants. Relevant rules and regulations, audit reports, Memoranda of Understanding (MOU), business plans, and discussion papers between Euroclear and market participants on the development of the infrastructure for cross-border clearing and settlement and custody services were made available.

150. Although the self-assessment of the BdF of the systems of Euroclear France contained an assessment of risk management in the context of recommendation 4 , in 
consultation with the authorities, it was decided to postpone the assessment of LCH-Clearnet SA until the new CPSS/IOSCO recommendation for central counterparties is finalized in order to take into account all relevant activities, governance structure, etc. This complete assessment of LCH-Clearnet will be conducted in the framework of an Article IV Consultation based on a self-assessment carried out by the French authorities.

\section{Main findings}

\section{Legal risk (recommendation 1)}

151. There is a consistent set of laws, regulations, and contracts that forms the legal foundation for custody, clearing and settlement of securities. All relevant laws and regulations are publicly available. Customer assets are protected by law against the bankruptcy of a custodian and there are clear restitution procedures in such a situation. Other key issues such as dematerialization, netting, securities lending arrangements and the establishment of collateral interest are well regulated. All laws, regulations and contractual arrangements are fully enforceable.

152. Due to the finality regulation in the Monetary and Financial Code securities transactions in the aforementioned systems are deemed to be final when they have been executed. Cancellations on the ground of the zero hour rule in the bankruptcy law cannot be raised against them retroactively. The finality regulation in combination with the rules and regulation of Euroclear France clearly define the moment of irrevocability and finality of transactions and endorse the legal validity of delivery versus payment.

153. A conflict of laws could arise owing to the open access policy of Euroclear France. The procedures to avoid such a conflict of law could be strengthened by requiring a legal opinion in case of admission of a foreign participant, especially in case of remote access.

\section{Pre-settlement risk (recommendations 2-5)}

154. Matching and confirmation are well established on the stock exchange, as are trades in the over the counter market. At least 95 percent of the settlement of stock exchange transactions is achieved through a rolling settlement procedure on $t+3$ or through a shorter settlement cycle in Relit+. Incentives are in place to ensure timely settlement and settlement failures are closely monitored. In the OTC market, settlement can be executed the same day in RGV2-TFT, which happens for about 30 percent of all transaction in the secondary markets. Current settlement practices ensure that the majority of OTC transactions in this system is settled within three days.

155. All transactions on the stock exchange are cleared and settled via LCH-Clearnet SA, which acts as a central counterparty. 


\section{Settlement risk (recommendations 6-10)}

156. Securities lending operations can be conducted through securities loans or repurchase agreements (repos). The law recognizes both instruments, as well as the validity of collateral transfers within the framework of securities lending.

157. Securities issued in France are almost all dematerialized (99.7 percent). The other securities issues, mostly warrants, Eurobonds and foreign securities are immobilized and adequate safe keeping procedures are in place within Euroclear France.

158. Euroclear France realizes delivery versus payments in both the systems it operates. RGV2-TFT is a model 1 DvP system that settles the securities and the cash position simultaneously online real time. Relit+ is a model 2 DvP system that settles the securities on a gross basis and netted the cash obligations. If securities are available in the account of the seller they are transferred to the account of the buyer and blocked until the final settlement of the cash obligation has taken place.

159. Final settlement occurs before the end of the day in both systems. If necessary, realtime, online intraday finality can be achieved in RGV2-TFT that allows for online, real-time settlement.

160. At present, there are no adequate safeguards that ensure timely settlement in case of a default of one of the participants in Relit+ and, in such a situation, Euroclear has to unwind the clearing. However, consultation between the overseers and all parties involved has resulted in an agreement to implement on short notice adequate measures to ensure timely settlement in case the participant with the largest obligation to pay is not able to fulfill its obligations.

161. Both systems of Euroclear settle in central bank money. However, in Relit+ cash settlement flows are quite concentrated since smaller participants make use of a settlement agent to settle their cash obligations, and, within that context are exposed to settlement bank risk. In 2003, more than 50 percent of all payments in Relit+ were concentrated in three settlement banks.

\section{Operational risk (recommendation 11)}

162. Even though the systems function well, backup facilities are available, and contingency measures are taken, some improvements are possible to the operational reliability and the scalability of the system. The second site is not located at an adequate distance of the main site. Within the business continuity objectives Euroclear France targets a maximum recovery time of four hours for a full fallback on the second site. However, during the last full fallback test seven hours were needed for operations to be processed normally. These results could be improved to ensure that the objectives for recovery could be met in a serious emergency situation. Within this context, testing of the contingency measures should preferably also include the participants. In practice, no major failure necessitating migration 
to the second site occurred in the period July 2002-July 2003, although there were numerous medium and minor incidents during this period.

\section{Custody risk (recommendation 12)}

163. Customers' assets are legally protected against the insolvency of Euroclear France, a custodian or an intermediary. If a loss of securities might occur, investors can be compensated for this loss or for the loss of cash in unfinished settlement procedures under the securities guarantees scheme. Segregation of securities is an obligation in France and the AMF has issued general regulations regarding the categories of services that can be offered by custodians and their duties and obligations. It has also set appropriate procedures for handling customer assets by a custodian, as well as requirements for the internal organization, accounting procedures and internal control of such an entity.

\section{Other issues (recommendations 13-19)}

164. Euroclear France is a fully owned subsidiary of Euroclear Bank. Nonetheless, the governance structure of Euroclear France has substantially improved after the takeover by Euroclear Bank and measures have been taken to ensure that users are consulted and can make clear their views about the policy of Euroclear France. Thus, for the time being, an effective governance structure exists. However, this could change drastically in the near future when the operational activities of local CSD's and Euroclear Bank will be integrated within the context of centralization of settlement processing functions. Key questions within these developments might be: (i) whether the present governance structure will still be effective to deal with potential conflicts of interest that could arise between the owner/operator of the systems and the users who are competitors in the market for clearing and settlement and custodial services; and (ii) how to define and serve the public interest of the newly infrastructure. As it stands now, custodians have distinct fears that future developments might harm their interests and will negatively influence their competitive position.

165. The access rules are disclosed to all potential applicants and are objective. Access is open for financial institutions and investment firms, whether established in France or abroad. Some French public law entities can participate as well. The rules for the termination of the business relationship between Euroclear France and a customer are clearly defined.

166. Supervision and oversight of Euroclear is well organized and clearly regulated. Because Euroclear France belongs to the Euroclear group and is active in various countries and markets in Europe, cooperation between the French authorities and the relevant authorities abroad is necessary and well established via a set of MOU with all relevant regulators/overseers abroad. Regular meetings and exchanges of information between the relevant authorities and with representatives of the Euroclear group take place in order to foster cooperation and coordinate the assessments made by the competent authorities of the related systems. 
Table 4. Summary of Main Findings and Recommended Corrective Action Plan

\begin{tabular}{|c|c|}
\hline Subject & Main Findings and Recommended Corrective Action Plan \\
\hline $\begin{array}{l}\text { Legal Risk } \\
\text { (Recommendation 1) }\end{array}$ & $\begin{array}{l}\text { Strengthen the procedures to avoid potential conflict of law issues by requiring } \\
\text { adequate legal opinions in case of foreign applicants } \\
\text { Euroclear France is expected to put in place a requirement for legal opinions to } \\
\text { ascertain the absence of any conflict of law issue. }\end{array}$ \\
\hline $\begin{array}{l}\text { Pre-settlement risk } \\
\text { (Recommendations 2-5) }\end{array}$ & None. \\
\hline $\begin{array}{l}\text { Settlement risk } \\
\text { (Recommendations 6-10) }\end{array}$ & $\begin{array}{l}\text { Adequate measures should be implemented in Relit }+ \text { as soon as possible to } \\
\text { ensure timely settlement in case the participant with the largest obligation to } \\
\text { pay is not able to settle. } \\
\text { To ensure timely settlement in case the participant with the largest obligation } \\
\text { to pay is not able to fulfill its obligations, a mutual guarantee fund } \\
\text { supplemented by a set of limits applied to the net cash positions in the system } \\
\text { is expected to be implemented before the end of } 2004 \text {. }\end{array}$ \\
\hline $\begin{array}{l}\text { Operational risk } \\
\text { (Recommendation 11) }\end{array}$ & $\begin{array}{l}\text { The resilience of the systems of Euroclear France could be upgraded by } \\
\text { conducting a thorough analysis of threats to the system and its organization, } \\
\text { reducing the amount of incidents, ensuring that there is enough (peak) capacity } \\
\text { so that in case of a serious technical breakdown of the systems the objectives } \\
\text { set for business recovery can be met, and designing the back up facilities with } \\
\text { a view to establishing an ability to cope with a wide-area disaster. } \\
\text { Several projects are planned by Euroclear France to improve the operational } \\
\text { reliability and the production capacity in } 2005 \text {. Also, a redesign of the } \\
\text { operation sites is foreseen in the near future with two synchronized sites and } \\
\text { one cold backup site located in another country in order to be able to cope with } \\
\text { wide-area disasters. }\end{array}$ \\
\hline $\begin{array}{l}\text { Custody risk } \\
\text { (Recommendation 12) }\end{array}$ & None. \\
\hline $\begin{array}{l}\text { Other issues } \\
\text { (Recommendations 13-19) }\end{array}$ & None. \\
\hline
\end{tabular}

\section{Authorities' response}

167. The recommendations of the IMF are in line with the findings of Banque de France and the AMF, the relevant overseers/regulators of Euroclear France. 


\section{Core Principles for Systemically Important PAYMent Systems (CPSIPS)}

\section{General}

168. The assessments of the Systemically Important Payment Systems (SIPS) in France against the Committee on Payment and Settlement Systems (CPSS) Core Principles took place in two missions in February and May 2004. The assessments covered three systems: Transferts Banque de France (TBF) (a public sector Real-Time Gross Settlement systemRTGS), Paris Net Settlement (PNS) (a private sector large-value payment system) and Système Interbancaire de Télécompensation (SIT) (a private sector retail payment system). The assessments involved discussions with directors and senior officials from several departments of the Banque de France (BdF). In addition, several meetings with the private sector operators (Centrale des Réglements Interbancaire, CRI, and Groupement pour un Système Interbancaire de Télécompensation, GSIT), the Bankers' Association and commercial banks took place.

169. The assessments benefited from previous assessments made by the BdF for each of the three systems. The ones for TBF and PNS had been written and finalized in the context of the activities at the level of the Eurosystem. The assessment on SIT was still preliminary and had not yet been commented on by its operator. Abundant material had been made available by all counterparties. Generally, the officials met during the assessment mission were competent, open and co-operative.

\section{Institutional and market structure}

170. Following the merger and consolidation process within the financial sector, roughly 1,000 credit institutions conduct business in France (compared to 1,608 in 1994). The Post Office's financial arm plays a significant role in the French financial system as it holds a significant number of demand accounts and time accounts.

171. In addition to cash, the check is still widely used in France. However, the relative share of checks in cashless payments has been declining since 1993. Direct debits have been very successful ever since their introduction in 1967. They are generally used for recurrent payments such as electricity, gas, phone and water bill payments. The use of the interbank order Titre Interbancaire de Paiement (TIP) has been growing steadily. A TIP works in the same way as a direct debit, except the payer is required to consent to each payment by signing the TIP form, which is sent with the corresponding invoice.

172. Credit transfers are also widely used in the retail area, for instance, for payments made by companies, government agencies and local authorities. The interbank exchange of all credit transfers takes place in paperless form. Ordinary transfers are settled on the day of presentation while credit transfers for payment on a future due date are presented two or three days in advance of the settlement.

173. Bank cards are mostly debit cards which can be used for both payments and cash withdrawals through a nationwide network of Point of Sale (POS) terminals and Automated 
Teller Machines (ATM). For several years, cards have been equipped with a computer chip which resulted in a decline of fraudulent transactions to a very low level. A specific network is used for the transmission and authorization for withdrawals and payments. This network enables an ATM or a POS terminal to obtain authorization from the issuing bank. This authorization also means that the payment is guaranteed for the beneficiary. At the end of 2001, 32,500 ATMs and 750,000 POS terminals were installed nationwide. As in other EU countries, the circulation of electronic money is still fairly limited. Currently, three consortiums are providing their e-money schemes.

174. The interbank payments area is dominated by three systems, each of which is considered systemically important by the French authorities. Large-value operations are processed in two systems: the RTGS system TBF which is the French component of the Trans-European Automated Real-Time Gross settlement Express Transfer system (TARGET). TBF is managed and operated by the BdF. The hybrid system PNS is managed and operated by the CRI. CRI is an interbank body owned by 10 banks and the central bank.

175. Retail transactions are processed in the French Automated Clearing House SIT. SIT is a deferred net settlement system and is managed and operated by GSIT, a group of 12 founding members (banks).

176. The banking industry and the BdF are continuing their efforts to improve the safety and efficiency of the payment infrastructure. At the BdF, a separate oversight unit has been established within the payment department in order to deepen the quality and independence of this activity. Both TBF and PNS, while technologically still modern systems, are approaching the end of their life cycles since they will be obsolete with the introduction of TARGET 2 in 2007. The clearing of an increasing number of retail payment instruments in SIT has led to the appraisal of the BdF that SIT is of systemic importance. Hence, SIT is one of the very few retail payment systems that has to comply with the Core Principles. One of the challenges for SIT will be the still unclear effects of the Single European Payments Area (SEPA) on the landscape for the clearing and settlement of retail payments.

\section{Prerequisites for effective payment systems oversight}

177. France fulfills all prerequisites for effective payment clearing and settlement systems. Historically, the private sector has been playing an important role both in the provision of payment instruments as well as of payment clearing services. The BdF, in turn, is also an established player in the area of payment services. In the field of payments, the relationship between the BdF and the banking sector is well established and co-operative. The needs of the users are accounted for in the development of the payment infrastructure.

178. The oversight of payment systems is three-tiered: defining the principles or standards underpinning their conception and operation, monitoring their implementation and lastly overseeing actual conditions of operation and use. The oversight activities are embedded into the framework which was developed by the Eurosystem. 
179. The legal framework is sound. Fraud and delays are minimal. Mechanisms for dispute resolution are in place and respected.

\section{Main findings}

180. The infrastructure for clearing and settlement of payments is generally well developed and modern. The functionality of the RTGS system, TBF, is more advanced than in most other countries. The other large-value payment system, PNS, relies on complex settlement algorithms that have become increasingly popular in recent years. The quality of the oversight activities of the BdF is sound and effective.

181. Some room for improvement was identified only in a few areas, for instance with regard to ensuring timely settlement in the multilateral netting system SIT. This system currently operates without protection against the default of the largest net debtor. The authorities and system operators have already identified steps to address this problem. The mission encourages these efforts, although it advises that the measures should be implemented as a matter of urgency and not be postponed until 2008.

182. Two of the three assessed systems, PNS and SIT, allow access only to a small number of direct participants who serve as settlement banks for several other financial institutions. Tiered structures can concentrate risk and increase the potential for widespread disruption if problems occur at a settlement bank. The mission came to the conclusion that neither safety nor efficiency would be lower with a broader direct access to these systems.

\section{Transferts Banque de France (TBF)}

\section{Legal foundation (CP 1)}

183. French law and the contractual arrangements within the framework of TBF payment system provide a well-established legal foundation for fund transfers in a real-time gross settlement system (RTGS). A consistent and reliable set of laws, regulations, and contractual arrangements form the legal basis for TBF and the payment transfers executed in this system. All relevant laws as well as contractual arrangements related to TBF between the different parties involved are fully enforceable.

184. Irrevocability and finality are clearly defined in the law and in the rules of the system; they are also ensured even in case an insolvency procedure is opened against a direct or indirect participant in the system. Although a zero-hour rule and a regulation on a suspect period exist under the French Bankruptcy law, these regulations are superseded for payment or financial instrument deliveries in a payment or securities settlement system (Art. L330 I-II of the Monetary and Financial Code). TBF falls within the scope of this finality regulation and is notified to the European commission as a payment system pursuant to the Settlement Finality Directive (directive 98/26 EC).

185. Collateral arrangements in payment and securities settlement systems are fully enforceable. The BdF as system operator requires foreign participants (both branches and 
remote members) applying to become participants in the system, to provide a legal opinion compliant with the terms of reference given by the Governing Council of the European Central Bank (ECB).

\section{Understanding and management of risks (CPs 2-3)}

186. The user specifications give a comprehensive description of the system design, functionalities, timetables and risk management procedures. The relevant rules and regulations of the system extend over a number of documents issued by the BdF and the CRI. For many issues documents of both sources are relevant, which might impair the accessibility.

187. Possible improvements were identified in the areas of readability (e.g., by adding an index) and accessibility (e.g., by the distribution through the Internet). While emergency procedures are described in general, the description is lacking some important details.

188. As an RTGS system with queuing facilities, which settles in central bank money, TBF offers protection against credit risk. Liquidity risk is addressed through unlimited intraday credit provided against collateral. Intraday liquidity in TBF is in ample supply mostly due to the generous eligibility criteria of the Eurosystem for acceptable collateral. In addition, optimization routines lead to very short queuing times in TBF.

\section{Settlement (CP 4-6)}

189. The payments are processed in real-time on a transaction-by-transaction basis. They are final (irrevocable and unconditional) from the moment they are credited to the account of the receiving bank. The settlement asset is central bank money.

\section{Security and operational reliability (CP 7)}

190. The availability of TBF has been very high in recent years (99.94 percent) after some technical improvements have been implemented that were triggered by one serious service disruption in 2001. The structure of TBF is complex mostly due to several interfaces and links to other systems. The complexity of the structure gives rise to some residual operational vulnerability.

191. For business continuity purposes, both the BdF and CRI have backup systems and secondary processing sites at their disposal, as well as monitoring and supervision. The secondary sites are at an adequate distance of the primary sites. All production and data communication back up facilities and disaster recovery procedures are tested regularly. A crisis team is installed in which the BdF, the CRI, the main ancillary systems managers and several users are participating. 


\section{Efficiency and practicability (CP 8)}

192. TBF has the usual features of RTGS systems for sending, queuing, and inquiring built in. In addition, optimization procedures facilitate the clearing positions of the different ancillary systems and also serve to promote the throughput in the system. An algorithm is available to solve imminent gridlocks. In terms of practicality, TBF provides all the characteristics of a modern RTGS system.

193. A deficiency of the system is its low-cost recovery. TBF is heavily subsidized by the BdF. From a strict accounting point of view, only 15 percent of all costs incurred (operating costs and investment costs) are covered by revenues. The lack of cost recovery can largely be explained by the fact that two large-value systems are competing in the French wholesale payments market. In addition, the separate settlement of the cash leg of securities transactions in central bank money in RGV2 (operated by Euroclear France) lowers the turnover in TBF relative to similar systems in other countries and might have impaired the attainment of full economies of scale.

\section{Fair and open access (CP 9)}

194. Access to TBF is fair and open since all credit institutions and investment firms established in France or other parts of the European Economic Area (EEA) are free to participate as long as they are authorized to carry on activities in France under the European passport.

\section{Governance (CP 10)}

195. Within the BdF there is an appropriate framework in place for operating, auditing and overseeing the system. In all important matters the BdF consults regularly with well-established user groups and forums.

\section{PNS}

\section{Legal foundation (CP 1)}

196. French law and the contractual relations within the framework of PNS provide a wellestablished legal foundation for funds transfers in PNS. A consistent and reliable set of laws, regulations, and contractual arrangements is in place that forms the legal basis for PNS and payment transfers executed in this system. All relevant laws, as well as contractual arrangements between the different parties involved within the framework of PNS, are fully enforceable.

197. Although a zero-hour rule exists in the French Bankruptcy law, this regulation is overruled for payment or financial instruments deliveries in a payment or securities settlement systems under the finality regulation in the Monetary and Financial Code (Art L330 I-II of the Monetary and Financial Code; see in this context the remarks on the scope of the finality protection in the above discussion on CP1 for TBF). PNS falls within the 
scope of this regulation and is recognized as a payment system falling under the EU Settlement Finality Directive (directive 98/26 EC). A receiving bank or its customer are not exposed to any retroactive actions, also not in the case the received payment is done on behalf of a so-called customer bank, a bank that makes use of a participant of PNS to settle its payment in this system. However, the relationship between the customer bank and its settlement agent does not fall under the finality protection and, thus, the settlement bank might be exposed to risk in case of an insolvency of its clients.

\section{Understanding and management of risks (CP 2-3)}

198. The rules and procedures of PNS enable participants to understand the risks resulting from their participation in the system under normal and under exceptional circumstances. The settlement algorithms are fully described and documented. Also, the rules for the rejection of payments, the handling of errors and other abnormal situations are outlined.

199. PNS enables participants to manage their credit and liquidity risks vis-à-vis their counterparties, not only via real-time gross settlement of payments, but also by setting bilateral limits on the amounts to be exchanged during the processing cycle. Outgoing payments that exceed this limit are queued. Incoming and outgoing queues are transparent to the individual participant. All payments settled are final (irrevocable and unconditional). Any funds received can be used to settle payment obligations to other participants. The participants are trained on a regular basis.

\section{Settlement (CP 4-6)}

200. PNS is a real-time gross settlement system that provides prompt final settlement during the day at the moment the account of the payer is debited and the account of the receiver is credited. The settlement asset is central bank money. Banks which use a settlement agent in PNS are still exposed to settlement bank risk.

\section{Security and operational reliability (CP 7)}

201. The availability of PNS has been very high in recent years (99.98 percent) and no major service disruptions occurred. The Audit department of the BdF carried out audits of the CRI platform in 1998 and 2000.

202. Contingency measures are in place to ensure business continuity. CRI has backup systems in place (all computers are duplicated, or clustered, and in a ready standby mode), together with a secondary production site for production purposes and a separate secondary site for monitoring and supervision. The secondary sites are located at an adequate distance from the primary site. All production, data communication backup facilities, and disaster recovery procedures are tested regularly. In the extreme situation where all production sites are unavailable and no communication exchange via the Society for World-wide Interbank Financial Telecommunication (SWIFT) or telephone is possible, a specific disaster procedure can be activated by the physical exchange of floppy disks. A crisis team is installed in which 
the BdF, the CRI, and the main ancillary systems managers and several users are participating.

\section{Efficiency and practicability (CP 8)}

203. Because of the complex offsetting algorithms, the queues are very small in PNS, making it possible for settlement to occur swiftly and efficiently. The features in terms of inquiry options and queue transparency are in line with international best practices. Hence, PNS can be rated as a system that is fully practical to its users.

204. According to its operators, PNS fully recovers its costs. It is, however, not known whether the cost accounting methods are based on a fair distribution, between CRI as the provider of PNS and the BdF as provider of TBF, of the costs for the use of common platforms operated by CRI and whether there might be cross-system subsidies.

\section{Fair and open access (CP 9)}

205. PNS is open to all banks and investment firms with a capital above EUR 250 million established in the EEA. ${ }^{22}$ This so-called own fund requirement means that smaller banks have to make use of a direct participant/settlement agent to settle their transactions in PNS (around 10 banks offer this services on a broad scale). Since PNS is now a settlement system with immediate finality, some doubts arise that the current limitation of access can still be justified. In terms of safety, a broader participation would reduce concentration risk without increasing credit or liquidity risk. In terms of efficiency, a larger number of direct participants would also not be detrimental since liquidity is abundant and inexpensive. Also, the various optimization algorithms tend to reduce the liquidity needed in the system.

\section{Governance (CP 10)}

206. The PNS system has an effective, accountable and transparent governance structure. Decisions are made by the Assemblée Générale (general assembly) of CRI shareholders acting as the majority of voters. CRI has set up different working groups in which the participants in the system can express their needs and concerns and make remarks. These groups monitor the participants' satisfaction with the system and participate in the formulation of desired changes to the system. They meet periodically and their conclusions are reported to the Assemblée Générale.

22 The capital requirement was lowered when PNS (then known as SNP) switched from an end-of-day multilateral net settlement system to a real-time system in 1999. 


\section{SIT}

\section{Legal foundation (CP 1)}

207. SIT is operated on a contractual law basis, ruled by the French civil code (agency rules for transfers, setoff rules for netting), the French commercial code (rules governing an Economic Interests Group) and the French Monetary and Financial Code. The Settlement Finality Directive (98/26/EC) was transposed into the French Monetary and Financial Code, supplemented by a decree (executive order) published on March 7, 2003 (see within this context the remarks above on the scope of the finality protection). Provisions as regards instruments of electronic payments apply within the French Law. There is no specific legislation in place relating to the electronic processing of payments settled through interbank settlement systems like the SIT.

208. The Charte Interbancaire Régissant les Conditions d'Échange (CIRCE) applies to the participants of SIT and provides for the rules of the system. The Monetary and Financial Code protects the finality of settlement in case a participant goes bankrupt. It also provides for the enforceability of payment orders as from the moment they have become irrevocable in SIT (see the discussion of this issue in the above section titled "Prerequisites for effective payment systems oversight.")

\section{Understanding and management of risks (CP 2-3)}

209. CIRCE (the rules of the system) and its technical annexes are binding for all participants. Direct participants have to sign CIRCE when joining the system. CIRCE comprises 14 chapters on SIT principles and user requirements supplemented by technical annexes and operational documentation. In total, CIRCE consists of more than ten binders. It contains all relevant information, for instance, a description of the system design and operating timetables, the rights and obligations of the relevant parties, a description of the financial risks, as well as contingency measures. These documents are currently only available in a paper-based format. The rules and regulations of the system are repeatedly updated.

210. SIT provides some tools to its direct participants to manage risks in the system, including information on their positions and account statements (twice a day). No financial access criteria exist in SIT. However, there is an upper limit for the value of a payment that can be processed in SIT (EUR 800,000). To limit the risk of the inability of a participant to settle its debit position in TBF, the settlement of SIT positions is structured in two periods: a control period and a settlement period. Since SIT is an ancillary system in the retail area that settles in TBF, the extent of the liquidity risk also depends on the functionality of TBF.

\section{Settlement (CP 4-6)}

211. SIT is a deferred net settlement system with one settlement cycle per day. Since there are no safeguards in place such as pre-pledged collateral or guarantees, the system is not protected against the default of the largest net debtor. This major vulnerability should be 
eliminated as a matter of urgency, all the more since in the present situation a default of a participants would not only bring forward liquidity risk but also serious operational turmoil if a unwinding of the transactions has to be executed, since participants already process payment orders received in their own system before the moment the final settlement is normally achieved in TBF.

\section{Security and operational reliability (CP 7)}

212. The operator GSIT is paying careful attention to issues of operational reliability. The availability of the systems has been perfect in recent years. Nonetheless, there is no ready backup in place. Hence, the potential down-time for the system could be as long as 48 hours - far too long for a systemically important payment system.

\section{Efficiency and practicability (CP 8)}

213. SIT is the only retail payment system in France. Its capacity is large enough to smoothly process an increasingly higher volume of transactions. SIT provides a reliable service to its direct participants. It appears to fit the needs of its users. Cost recovery is achieved and the transaction fees are at an internationally competitive level.

\section{Fair and open access (CP 9)}

214. The access criteria of SIT can be considered as fairly restrictive. Out of some 1,000 participants only 14 are allowed to be direct participants (a volume-based criterion is in place). According to Core Principle 9, access restrictions are to be justified on the grounds of safety or efficiency. Safety does not seem to be a sufficient reason here, since the settlement values in SIT are relatively low, for a SIPS, and intraday credit in TBF is plentiful and inexpensive. If safety concerns existed nonetheless, they could - in light of CP III-be addressed more appropriately with financial soundness criteria rather than with the current volume-based criteria. In terms of efficiency, there appears to be a few degrees of freedom since the system could cope with a few additional members without jeopardizing the quality and reliability of the service. The "power of netting" also cannot count as an efficiency argument, since the netting ratio is already fairly low.

\section{Governance (CP 10)}

215. The governance structure is appropriate and in line with that of private sector systems in other countries. The rules regarding governance arrangements are written down in accessible documents. The Management Committee (comité de direction) is composed of representatives of the founding members as well as other relevant parties from the financial sector (including the BdF).

216. The Executive Committee (le bureau) is composed of the Chairman of GSIT, a BdF representative, five representatives of the GSIT Management Committee, and the General Manager of GSIT. It is mainly a consultative body providing assistance to the chairman and the General Manager. The Executive Committee and the Management Committee of GSIT 
meet every other month. General Meeting is composed of all the members of GSIT. They have the right to approve the accounts of the past exercise, validate the budget, elect and revoke the General Manager, the account controller and the management controllers, admit new members and exclude current members, as well as modify the statutes.

\section{The responsibilities of the central bank}

\section{Disclosure of objectives (A)}

217. The BdF has a sound legal framework on which its oversight activities in the area of systemically important payment systems are based. The BdF has close relationships with the banking industry. It informs the public on an in-depth basis about new developments and expected changes. The public is also well informed about the role of the BdF and its objectives in the payments area.

\section{Oversight of own systems (B)}

218. The organizational setup with the division between operations and oversight allows the BdF to oversee TBF effectively. The assessment of TBF is thorough, complete, and of good quality. The skills of the oversight team are appropriate. However, for some issues, such as operational reliability, the cooperation with other internal and external entities (in particular auditors) could be strengthened.

\section{Oversight of private sector systems (C)}

219. The BdF has a sound legal basis for the oversight of payment systems operated by the private sector. The same unit that is overseeing TBF is also in charge of the oversight of the private sector systems. As with TBF, the oversight activities are performed thoroughly and professionally. By and large, the BdF has identified the right shortcomings and has taken steps to mitigate them. As for TBF, the overseers could push for more frequent and regular information security audits.

\section{Cooperation with other authorities (D)}

220. The BdF is in close cooperation with foreign peers, in particular the central banks of the Eurosystem. It has signed several MOU with other authorities, and its network for cooperation is well established. The $\mathrm{BdF}$ is paying appropriate attention to matters of cooperative oversight. 
Table 5. Summary of Main Findings of Assessment of Observance of CPSS Core Principles for Systemically Important Payment Systems and of Central Bank's Responsibilities

\begin{tabular}{|c|c|}
\hline Subject & Main Findings and Recommended Corrective Action Plan \\
\hline $\begin{array}{l}\text { Well-founded legal basis in all relevant } \\
\text { jurisdictions (CP 1) }\end{array}$ & No recommendation. \\
\hline $\begin{array}{l}\text { Understanding of the system's impact on risks; } \\
\text { and procedures for the management of risks } \\
\text { (CPs 2-3) }\end{array}$ & $\begin{array}{l}\text { In TBF and PNS, the procedures should give clearer } \\
\text { guidance on the behavior of the participants in various } \\
\text { emergency situations. }\end{array}$ \\
\hline $\begin{array}{l}\text { Final settlement; inability to settle by the } \\
\text { participant with the largest single settlement } \\
\text { obligations (CPs 4-5) }\end{array}$ & $\begin{array}{l}\text { In SIT, protection against the default of the largest net } \\
\text { debtor should be put in place as a matter of urgency. }\end{array}$ \\
\hline Assets for settlement (CP 6) & $\begin{array}{l}\text { In PNS and SIT, the authorities should analyze the } \\
\text { concentration risk created by the small number of direct } \\
\text { participants through which the payments of indirect } \\
\text { participants and of customer banks are channeled. }\end{array}$ \\
\hline $\begin{array}{l}\text { Security and operational reliability; and } \\
\text { contingency arrangements (CP 7) }\end{array}$ & $\begin{array}{l}\text { For TBF, it should be determined whether there are ways } \\
\text { to simplify the currently complex structure of the system. } \\
\text { The resilience of SIT should be enhanced as soon as } \\
\text { possible by the introduction of a hot-standby back-up site. }\end{array}$ \\
\hline $\begin{array}{l}\text { Market practicality and efficiency for the } \\
\text { economy (CP 8) }\end{array}$ & $\begin{array}{l}\text { For PNS and TBF, it should be investigated whether the } \\
\text { costs of the shared platform can be allocated in a more } \\
\text { appropriate way. }\end{array}$ \\
\hline $\begin{array}{l}\text { Objective and publicly disclosed criteria for } \\
\text { participation (CP 9) }\end{array}$ & $\begin{array}{l}\text { Neither efficiency nor safety would suffer from a removal } \\
\text { of the capital requirements to access PNS. Under the } \\
\text { current design of SIT, the volume-based access criteria } \\
\text { could be lowered or replaced by easier conditions taking } \\
\text { into account soundness criteria. }\end{array}$ \\
\hline $\begin{array}{l}\text { Governance of the system should be effective, } \\
\text { transparent and accountable (CP 10) }\end{array}$ & No recommendation. \\
\hline $\begin{array}{l}\text { Responsibility A - The central bank should } \\
\text { define clearly its payment system objectives and } \\
\text { should disclose publicly its role and major } \\
\text { policies with respect to systemically important } \\
\text { payment systems. }\end{array}$ & No recommendation. \\
\hline $\begin{array}{l}\text { Responsibility B - The central bank should } \\
\text { ensure that the systems it operates comply with } \\
\text { the core principles. }\end{array}$ & $\begin{array}{l}\text { The BdF should consider ways to strengthen the cooperation } \\
\text { of its oversight unit with other internal and external entities } \\
\text { (in particular auditors), for instance in the area of } \\
\text { operational reliability and security. }\end{array}$ \\
\hline Responsibility C - The central bank should & It is recommended that the overseer press the operators to \\
\hline
\end{tabular}




\begin{tabular}{|l|l|}
\hline \multicolumn{1}{|c|}{ Subject } & Main Findings and Recommended Corrective Action Plan \\
\hline $\begin{array}{l}\text { oversee observance with the core principles by } \\
\text { systems it does not operate and it should have the } \\
\text { ability to carry out this oversight. }\end{array}$ & $\begin{array}{l}\text { have their systems audited in a more systematic and regular } \\
\text { way. }\end{array}$ \\
\hline $\begin{array}{l}\text { Responsibility D - The central bank, in } \\
\text { promoting payment system safety and efficiency } \\
\text { through the core principles, should cooperate } \\
\text { with other central banks and with any other } \\
\text { relevant domestic or foreign authorities. }\end{array}$ & No recommendation. \\
\hline
\end{tabular}

\section{Authorities' response}

221. The Banque de France takes note that the IMF largely endorses its own findings regarding both the overall situation of the French payment infrastructure and the assessments of TBF, PNS and SIT, performed against the Core Principles.

222. The Banque de France would also like to mention that it has already taken several steps to urge payment systems to achieve full observance with the Core Principles, in the few remaining areas where some improvement is still needed. In particular, compliance of SIT with CP V is planned to be achieved no later than 2008, in line with the policy stance endorsed by the Eurosystem.

\section{FATF RECOMMENDATIONS FOR ANTI-MONEY LAUNDERING AND COMBATING THE FINANCING OF TERRORISM}

\section{Introduction}

223. This assessment provides a summary of the level of compliance with the FATF $40+8$ Recommendations ${ }^{23}$ and provides recommendations to strengthen compliance. The views expressed in this document are those of the assessment team and do not necessarily reflect the views of the government of France or the Board of the IMF.

${ }^{23}$ The Financial Action Task Force (FATF) was founded in Paris at the 1989 G-7 Summit to combat money laundering arising from drugs and other criminal activities. The organization is comprised of 31 countries, the European Commission, and the Gulf Cooperation Council. Its Recommendations are widely recognized as the key set of anti-money laundering (AML) standards. In October 2001, FATF issued new international standards to combat terrorism financing, in the form of eight special Recommendations, thus the shorthand "FATF 40+8" reference. 
224. To conduct the assessment, the team reviewed the relevant Anti-Money Laundering and Combating the Financing of Terrorism (AML/CFT) laws and regulations and supervisory and regulatory systems in place to deter money laundering (ML) and the financing of terrorism (FT) among prudentially regulated financial institutions and other financial intermediaries. The team also reviewed the capacity and implementation of criminal law enforcement systems. The assessment is based on the information available at the time the assessment mission concluded on April 22, 2004. Some additional information was provided by the French authorities following the conclusion of the mission that now has been taken into account in finalizing the assessment.

\section{Main findings}

\section{Criminal justice measures and international cooperation}

\section{Criminalization of money laundering and the financing of terrorism}

225. France has ratified the United Nations Convention on Illicit Drugs and Psychotropic Substances (Vienna Convention), the UN International Convention for the Suppression of the Financing of Terrorism and the UN Convention Against Transnational Organized Crime 2000 (Palermo Convention). France is also a party to the Council of Europe Convention on Laundering, Search, Seizure and Confiscation of the Proceeds from Crime (Strasbourg Convention).

226. Legal provisions for the criminalization of money laundering and terrorist financing are in place. The scope of predicate offences for ML is very extensive and covers all crimes and misdemeanors, including FT and fiscal fraud. FT is criminalized comprehensively.

\section{Confiscation of proceeds of crime or property used to finance terrorism}

227. French legislation provides broad possibilities to seize any assets in the course of investigations, either by officers of judicial police or on instruction of the judiciary. A special mechanism enables temporary measures to be taken on assets from persons under suspicion in order to safeguard an eventual confiscation. Although, in theory, all assets of a convicted person can be confiscated, in practice, confiscation measures generally apply to the assets seized in the course of the judicial procedure. As an alternative, fines can be increased to half the level of the laundered funds.

228. France implements the United Nations Security Council Resolutions (UNSCR) 1267, 1269, 1333, 1373, and 1390 through directly applicable European Union (EU) legislation. France is currently unable to comply fully with UN Security Council Resolution 1373 with regard to terrorists or terrorist groups from within the European Union as they are not covered by EU Council Regulations. The authorities are in the process of preparing a draft law on the freezing of property that would permit freezing the funds and financial assets of European community nationals. No timeframe has been set for the adoption of such a law. 
229. France does not currently keep statistics on the amounts of property frozen, seized, and confiscated relating to ML, the predicate offences, and FT. The authorities should consider the compilation of relevant statistical data in this area.

The Financial Intelligence Unit (FIU) and processes for receiving, analyzing, and disseminating intelligence

230. Treatment of Information and Action against Clandestine Financial Circuits (TRACFIN), the FIU in France, is an Egmont member and has been operational since 1991. It can issue blocking or freezing instructions which are valid for 12 hours where suspicious transactions are reported prior to their execution. This procedure was used only on seven occasions since TRACFIN became operational and has produced minimal results.

231. The interaction between TRACFIN, the supervisory authorities and law enforcement has improved markedly recently and appears to be reasonably efficient. Domestic cooperation has been enhanced by the creation in 2001 of the Liaison Committee which comprises representatives of the reporting parties, the supervisory authorities and a number of administrations. Notwithstanding that it co-chairs the Liaison Committee, there would appear to be room for a more active involvement of members of the judiciary in this forum.

232. TRACFIN can cooperate with its foreign counterpart units to share intelligence information and data likely to be linked to ML or FT on the basis of the national legislation that is consistent with the Egmont Group principles. In order to enhance this cooperation, TRACFIN has concluded cooperation agreements with 24 counterpart units so far. At the EU level, TRACFIN frequently uses FIU.Net to query its closest partners abroad. Further, it is sending requests to foreign FIUs on cases with an international dimension, though not yet systematically.

233. The number of Suspicious Transaction Reports (STR) has increased rapidly since 2000, but still seems rather low compared to the financial and economic activity on the French market and the recent increase in reporting has not been accompanied by a significant increase in the overall quality of reports.

234. Although it has increased, the number of files forwarded by TRACFIN to the judicial authorities is still relatively limited (291 files in 2002, representing between 8-10 percent of all STRs received). TRACFIN indicates that this is mainly due to the poor quality of a large number of STRs. Further, the statistics currently maintained by TRACFIN are not sufficiently detailed.

235. A working group of the Liaison Committee is currently working on establishing an electronic reporting form that should enhance the analytical capabilities of both the reporting parties and TRACFIN, improve the overall quality of STRs and the quantity and quality of transmissions by TRACFIN, and assist in the compilation of more detailed statistics.

236. There are difficulties arising with a number of overseas departments and territories, in particular, Guyana where not a single STR has been produced since 2000. 
237. TRACFIN has a staff which originates from the public administration, and representatives of other authorities (Police judiciaire, Office Central de Répression de la Grande Délinquance Financière, Gendarmerie). The training system is internal and somewhat ad hoc.

\section{Law enforcement and prosecution authorities, powers, and duties}

238. ML and FT investigations are carried out by law enforcement under supervision of the judiciary. The Police judiciaire, the Préfecture de Police, the Gendarmerie and the Douane have established divisions specialized in economic and financial crime, including ML, that also benefit from specific training programs. Depending on the stage of the enquiries, they can use a wide range of investigative techniques but a large number of cases are not pursued due to insufficient financial and human resources. A recent reform by the Law of March 9, 2004 entering into force on October 1, 2004 and introducing specialized jurisdictions is expected to enhance the overall capacity of the judicial system to combat financial crime.

239. The number of convictions for ML is on the increase, although the ML offence does not appear to be used as frequently as it might be due mainly to the difficulty in establishing the illegal origin of the funds. Courts appear to have adopted a pragmatic solution to this difficulty that consists in qualifying the facts differently and pursuing cases under other offences than the ML offence (abus de biens sociaux, association de malfaiteurs, etc.). While a recent case indicates that a conviction for (general) ML can be pronounced without the predicate offence being specifically identified, additional reflection is needed on the obstacles that requiring proof of the predicate offence constitutes for an effective fight against ML.

240. Despite the efforts and determination of the authorities involved in fighting terrorism financing, no significant results in terms of convictions have been obtained so far, mainly due to the recent incrimination of FT and to the complicated and time consuming enquiries, in particular the difficulty of linking suspicious financial movements with terrorist activities. A pragmatic solution is to qualify the facts under investigation as association de malfaiteurs.

241. France allocates significant resources to the implementation of ML and FT laws. Law 75-701 of August 6, 1975 established courts specializing in economic and financial matters to handle complex proceedings including ML. The law on adapting the administration of justice to the developments of criminality that was recently adopted creates interregional courts specializing in highly complex cases involving organized crime and economic and financial crime.

\section{International cooperation}

242. France pursues a policy of active international cooperation and has an impressive set of bilateral and multilateral treaties for MLA and extradition in ML and FT cases. France has a number of arrangements in place for law enforcement authorities to exchange information regarding the subjects of investigations with their international counterparts, based on 
agreements in force and by other mechanisms for cooperation, including liaison magistrates, and at the European level, participation in the European Judicial Network and Eurojust. However, to date, there have been no efforts to record the number, source, and purpose of requests for information exchange and their resolution.

243. France provides timely and effective follow-up to mutual legal assistance requests and maintains statistics on all mutual legal assistance and other requests made or received, relating to ML, the predicate offences, and FT, as well as whether the requests were accepted or rejected. However, the nature and ultimate result of requests are not reflected in the statistics.

244. French law provides that the confiscation of assets on French territory operates a transfer of property to the state unless otherwise agreed with the requesting state. In addition, the sharing of assets may be provided in a bilateral treaty. France has currently one bilateral treaty providing for the transfer or the sharing of assets with another country when confiscation is a result of coordinated law enforcement actions.

\section{Preventive measures for financial institutions}

245. The institutional framework for financial sector regulation, supervision and licensing is organized sectorally. Regulation-making authority rests largely with the Minister of the Economy, as a result of the Law on Financial Security of 2003. The Comite des établissements de Crédit et des Entreprises d'Investissement (CECEI) licenses credit institutions and investment firms other than portfolio management firms (credit institutions and investment firms), the Comité des Entreprises d'Assurance (CEA) licenses insurance companies and the Autorité des Marchés Financiers (AMF) licenses, inter alia, portfolio management firms, direct marketers of financial products (démarcheurs) and investment advisers. Informal funds transfer businesses are subject to the licensing requirement for credit institutions. Licensing requirements include "fit and proper" testing of managers and significant shareholders. Other financial entities are subject to registration requirements, notably insurance brokers, currency exchangers, direct marketers and investment advisors, with varying degrees of "fit and proper" testing. In general, AML/CFT internal controls policies and procedures are not taken into account for licensing purposes.

246. The Commission Bancaire (CB) supervises credit institutions and investment firms for AML/CFT compliance; the Commission de Contrôle des Assurances (CCA) has similar responsibilities for insurance companies and brokers and the AMF for portfolio management firms, direct marketers and investment advisers. The Inspection Générale des Finances (IGF) is responsible for AML/CFT supervision of la Poste's financial services.

247. Enforcement and sanction powers of supervisory authorities are generally appropriate. ${ }^{24}$ The authorities have taken strong enforcement action when unlicensed

${ }^{24}$ The IGF does not have authority to impose sanctions on la Poste. 
informal funds transfer businesses have been discovered, although experience with such cases has not been extensive. However, AML/CFT supervisory efforts and corresponding resources are relatively low with respect to life insurance companies and brokers, individual and collective portfolio management firms, direct marketers and la Poste. The number of on-site inspections and corresponding staff resources for these sectors is relatively low and there have been few sanctions imposed for failure to comply with AML/CFT requirements. When looked at in the context of historically relatively low rate of reporting of suspicious transactions from these sectors, it is consequently difficult to assess whether AML/CFT requirements are being effectively implemented overall.

248. The legal framework for AML/CFT preventive measures is comprehensive and the regulation and supervision of credit institutions and investment firms other than portfolio management firms is of a high standard. The scope of sectoral application extends well beyond the standard. That said, the regulatory framework remains a work in progress, notably with respect to insurance companies and brokers, individual and collective portfolio management firms, direct marketers and currency exchangers.

249. For insurance companies and portfolio management firms, there is generally too much reliance on non-enforceable supervisory or industry recommendations to assist financial entities in implementing legal requirements and not enough on regulations and enforceable guidelines. For currency exchangers, direct marketers and la Poste, there is little, if any, additional guidance at this stage. Regulatory initiatives are underway however, notably in connection with the implementation of the revised FATF standards.

250. The Monetary and Financial Code and Decree 91-160 of February 13, 1991 provide an adequate framework for customer identification. Nonetheless, beyond some supervisory and industry recommendations, there is generally insufficient guidance as to what constitutes adequate customer acceptance policies and procedures and, in particular, what are the reasonable steps to be taken to identify beneficial owners of accounts and transactions.

251. While customer identification requirements apply both at the subscription and redemption stages, capitalization bonds/contracts may present certain ML/FT risks.

252. The Monetary and Financial Code requires that financial entities closely examine any large transaction that exceeds 150,000 euros (when this is normally not customary for the customer) and which is unusually complex and does not appear to have any economic or lawful purpose, and to retain such findings in writing. Formulated as such, this requirement would suggest that if the customer's transactions typically exceed this threshold, then there would be no obligation to exercise enhanced vigilance, even though such transactions may be complex or display unusual patterns. Moreover, while it may be appropriate to set a threshold for "unusual large transactions," it is somewhat limiting with respect to "complex" transactions or "unusual patterns of transactions."

253. While the Minister of the Economy, Finance and Industry regularly informs financial entities of countries that do not have adequate AML/CFT systems, there is no specific legal 
requirement for financial entities to give special attention to business relations and transactions with persons in such countries.

254. Financial entities are required to have screening procedures for hiring employees. The requirements focus largely on competency and are silent on the issue of integrity. Employee training appears to be implemented effectively with respect to credit institutions, investment firms, insurance companies and la Poste.

255. The requirement that financial entities report suspicious transactions has evolved/expanded over the past decade. However, the scope of the reporting requirement is not aligned with and is indeed narrower than that of the predicate offences for money laundering, which covers all crimes and misdemeanors, including fiscal fraud. A suspicion of a fiscal misdemeanor, for example, is not required to be reported. As such, the reporting regime falls short of requiring that funds suspected of stemming from any criminal activity be reported. This may be a source of confusion for reporting entities regarding whether or not to report particular transactions and could expose them to compliance risks. This could potentially reduce the effectiveness of the regime.

256. Additional reporting requirements have been introduced in recent years (e.g., for certain transactions involving residents of countries that do not apply FATF AML/CFT requirements or trusts where the identities of the settlor, trustee or beneficiaries of trusts are not known). However, the benefits of these additional reporting requirements (notably the one in relation to trusts) are unclear and could potentially draw away resources (i.e., of financial entities and TRACFIN) that might otherwise be used in the detection of suspicious transactions.

257. The legal framework for AML/CFT internal controls is supplemented by comprehensive regulations for credit institutions and investment firms. In the case of insurance companies and portfolio management firms, there is reliance instead on supervisory and professional recommendations that are not as comprehensive.

258. The Monetary and Financial Code requires that financial entities ensure that their branches and subsidiaries that are located abroad comply with the requirement to pay special attention to certain transactions. However, other than for credit institutions and currency exchangers, there appears to be no specific requirements for financial entities to ensure the comprehensive application of AML/CFT requirements to branches and majority owned subsidiaries located abroad.

\section{Summary assessment against the FATF recommendations}

259. The overall legal and institutional framework currently in place is comprehensive, and France maintains a high level of compliance with the FATF $40+8$ Recommendations. Moreover, France has gone beyond the standard in a number of areas, including in the sectoral coverage of its regime and the reporting requirements for imports and exports of monetary instruments. However, further improvements could be achieved in some areas, mainly: the implementation of UN Security Council Special Resolution on terrorism 
financing, as in other European countries operating within the European Union regulatory framework; the overall quality of STRs; AML/CFT regulation, supervision and enforcement for sectors other than credit institutions and certain investment firms; and requirements for increased diligence and internal controls.

\section{Table 6. Recommended Action Plan to Improve Compliance with the FATF Recommendations}

\begin{tabular}{|c|c|}
\hline Reference FATF Recommendation & Recommended Action \\
\hline \multicolumn{2}{|l|}{ Recommendations for AML } \\
\hline $\begin{array}{l}\text { Scope of the criminal offence of money } \\
\text { laundering (FATF 4-6) }\end{array}$ & $\begin{array}{l}\text { Additional reflection is needed on the obstacles that requiring } \\
\text { proof of the predicate offence constitutes for an effective fight } \\
\text { against ML. }\end{array}$ \\
\hline $\begin{array}{l}\text { Customer identification and } \\
\text { record-keeping rules (FATF 10-13) }\end{array}$ & $\begin{array}{l}\text { Introduce more detailed requirements as to what constitutes } \\
\text { adequate customer acceptance policies and procedures and, in } \\
\text { particular, what are the reasonable steps to be taken to identify } \\
\text { beneficial owners of accounts and transactions. } \\
\text { Review the ML/FT risks associated with capitalization } \\
\text { bonds/contracts and take corrective measures, as appropriate. }\end{array}$ \\
\hline $\begin{array}{l}\text { Increased diligence of financial } \\
\text { institutions (FATF 14-19) }\end{array}$ & $\begin{array}{l}\text { Review and broaden requirement to pay special attention to } \\
\text { certain transactions. } \\
\text { Align the scope of the reporting requirement with that of the } \\
\text { predicate offences for money laundering. } \\
\text { Review the usefulness of reporting requirements other than the } \\
\text { reporting of suspicious transactions. } \\
\text { Introduce more detailed internal control requirements via } \\
\text { regulations, guidelines or other enforceable means for financial } \\
\text { entities other than credit institutions and investment firms. } \\
\text { Establish legal requirement that financial entities also take } \\
\text { integrity into account when hiring employees, notably for } \\
\text { sensitive positions. } \\
\text { Further assist sectors other than credit institutions, investment } \\
\text { firms and insurance companies in developing employee training } \\
\text { programs. }\end{array}$ \\
\hline
\end{tabular}




\begin{tabular}{|c|c|}
\hline Reference FATF Recommendation & Recommended Action \\
\hline $\begin{array}{l}\text { Measures to cope with countries with } \\
\text { insufficient AML measures (FATF 20-21) }\end{array}$ & $\begin{array}{l}\text { Establish requirement for financial entities to ensure the } \\
\text { comprehensive application of AML/CFT requirements to } \\
\text { branches and majority owned subsidiaries located abroad. } \\
\text { Introduce requirements for financial institutions to pay special } \\
\text { attention to business relations and transactions with persons and } \\
\text { legal entities in jurisdictions that do not have adequate systems } \\
\text { in place to prevent and deter ML or FT. }\end{array}$ \\
\hline $\begin{array}{l}\text { Implementation \& role of regulatory and } \\
\text { other administrative authorities } \\
\text { (FATF 26-29) }\end{array}$ & $\begin{array}{l}\text { Increase reporting parties' awareness of the existence of } \\
\text { TRACFIN's opposition powers and extend the period of } \\
12 \text { hours to at least } 24 \text { hours. } \\
\text { Increase the Judiciary's involvement in the Liaison Committee. } \\
\text { Improve TRACFIN's dissemination ratio and ensure that it is } \\
\text { systematically informed of the outcome of transmissions made } \\
\text { to the judicial authorities. } \\
\text { TRACFIN and supervisory authorities to provide further } \\
\text { guidance and ML typologies to reporting entities to improve } \\
\text { detection and reporting of suspicious transactions, the quality of } \\
\text { STRs and overall implementation of AML/CFT requirements. } \\
\text { Reach out to the DOM-TOM and monitor their compliance with } \\
\text { AML/CFT obligations. } \\
\text { Monitor adequacy of TRACFIN's current staffing levels in view } \\
\text { of the increasing number of STRs and the perceived need for } \\
\text { outreach efforts vis-à-vis certain sectors. } \\
\text { Consider pooling expertise in financial and terrorist-related } \\
\text { aspects in one service. } \\
\text { Increase supervisory resources of the CCA and the AMF and } \\
\text { formalize training of supervisory staff. Shift responsibility for } \\
\text { AML/CFT supervision and enforcement of la Poste to the CB or } \\
\text { at a minimum increase supervisory efforts and resources of the } \\
\text { IGF. } \\
\text { Require that AML/CFT internal controls be taken into account } \\
\text { in the licensing of financial entities. } \\
\text { Where possible, supervisors should issue enforceable guidelines } \\
\text { in support of the legal and regulatory framework. }\end{array}$ \\
\hline $\begin{array}{l}\text { Administrative Cooperation - Exchange } \\
\text { of information relating to suspicious } \\
\text { transactions (FATF 32) }\end{array}$ & $\begin{array}{l}\text { TRACFIN should continue and enhance its efforts in } \\
\text { systematically querying foreign FIUs in cases with an } \\
\text { international dimension. }\end{array}$ \\
\hline
\end{tabular}




\begin{tabular}{|l|l|}
\hline \multicolumn{1}{|c|}{ Reference FATF Recommendation } & \multicolumn{1}{c|}{ Recommended Action } \\
\hline $\begin{array}{l}\text { Other forms of cooperation - Basis \& } \\
\text { means of cooperation in confiscation, } \\
\text { mutual assistance, and extradition } \\
\text { (FATF 33-35) }\end{array}$ & $\begin{array}{l}\text { Consider entering into additional arrangements providing for the } \\
\text { transfer or the sharing of assets with another country when } \\
\text { confiscation is a result of coordinated law enforcement actions. }\end{array}$ \\
\hline $\begin{array}{l}\text { Other forms of cooperation - Focus of } \\
\text { improved mutual assistance on money } \\
\text { laundering issues (FATF 36-40) }\end{array}$ & $\begin{array}{l}\text { Efforts should be made to record the number, source, and } \\
\text { purpose of requests for information exchange and their } \\
\text { resolution by law enforcement authorities } \\
\text { Further develop statistics maintained with regard to mutual legal } \\
\text { assistance by including purpose/nature and results of requests. }\end{array}$ \\
\hline Special recommendations on terrorist financing \\
\hline $\begin{array}{l}\text { III. Freezing and confiscating terrorist } \\
\text { assets }\end{array}$ & $\begin{array}{l}\text { Proceed with the adoption of a domestic act to enable France to } \\
\text { comply fully with UNSCR 1373. }\end{array}$ \\
\hline VI. Alternative Remittance & $\begin{array}{l}\text { Review and monitor the adequacy of enforcement efforts with } \\
\text { respect to unlicensed informal funds transfer businesses and } \\
\text { develop complementary public outreach /awareness raising } \\
\text { activities. }\end{array}$ \\
\hline
\end{tabular}

Table 7. Other Recommended Actions

\begin{tabular}{|l|l|}
\hline \multicolumn{1}{|c|}{ Reference } & \multicolumn{1}{|c|}{ Recommended Action } \\
\hline Statistics & $\begin{array}{l}\text { Maintain comprehensive statistics on the amounts of property } \\
\text { frozen, seized, and confiscated relating to predicate offences, ML } \\
\text { and FT. } \\
\text { Consider the establishment of a centralized body responsible for } \\
\text { managing seized and confiscated assets. } \\
\text { TRACFIN should consider maintaining more detailed/refined } \\
\text { statistics that would give a better insight on the performance and } \\
\text { characteristics of all the components of the AML/CFT efforts. }\end{array}$ \\
\hline $\begin{array}{l}\text { Designated non-financial businesses and } \\
\text { professions (DNFBP) }\end{array}$ & $\begin{array}{l}\text { Review options for the regulation and supervision of non- } \\
\text { financial businesses and professions and designate competent } \\
\text { supervisory authorities. }\end{array}$ \\
\hline $\begin{array}{l}\text { Overall Capacity of Judicial System in } \\
\text { Combating Financial Crime }\end{array}$ & $\begin{array}{l}\text { Monitor the implementation of the recent reform (Law of } \\
\text { March 9, 2004 entering into force on October 1, 2004) } \\
\text { introducing specialized jurisdictions that is expected to enhance } \\
\text { the overall capacity of the judicial system to combat financial } \\
\text { crime. }\end{array}$ \\
\hline VII. Wire transfers & $\begin{array}{l}\text { Requirements for Special Recommendation VII should be put in } \\
\text { place in early 2005, in accordance with FATF Interpretative Note. }\end{array}$ \\
\hline
\end{tabular}




\section{Authorities' responses}

260. The French authorities wish to thank the members of the IMF assessment team for all the work done to prepare this fair and balanced report. Notwithstanding, they have the following comments:

\section{General comments}

261. France has long been proactive and vigilant in ensuring that its overall legal and institutional framework actually deters money laundering. In this perspective, tools such as the restrictions on the use of cash as a mean of payment for sums higher than a certain threshold are worth mentioning. The dematerialization of bearer shares completed in the mid-1980s contributes to ensuring the transparency of beneficial ownership. In the same vein, the general provision prohibiting the endorsement of checks contributes to prevent their use for money laundering.

262. France can endorse most of the recommendations put forward by the assessment team. It has already engaged in efforts to implement them. The extension of the liaison committee to non-financial professions will lead to further outreach towards them, and will facilitate the development of more guidance for these professions. Last year's reforms of the organization of the supervisory bodies for nonbank financial institutions explicitly took into account the objective of strengthening their contribution and mobilization in the fight against money laundering. Many of the findings of the assessment team will be factored into the preparatory work already launched by the French authorities to implement the revised FATF recommendations.

\section{Specific issues}

263. Regarding TRACFIN's role, it is worth emphasizing that the French FIU has already taken steps to improve the quality of STRs and to strengthen the impact of the fight against money laundering in French overseas departments and territories. TRACFIN staffing has recently been increased. Moreover, the tools necessary to improve the statistical data on STRs are currently under development.

264. As for the AMF, its AML/CFT related powers were significantly extended by the Financial Security Act implemented on November 24, 2003. Since then, the priority has been and remains the enhancement of its regulatory framework so that it can efficiently exercise the full extent of its powers. A related action plan, which includes strengthening the human resources and additional training, is currently being finalized. Moreover, the AMF plans, in early October 2004, to put forward for public consultation a revision of its general regulation with a view to complete them in the following months.

265. As a matter of accuracy, the French authorities note that the AMF already takes into account the existence of internal control policies and procedures in its licensing process. 
266. Regarding the collection of statistical data on the amounts of property frozen, seized and confiscated related to money laundering and terrorist financing, the Ministry of Justice will roll out in the coming months new software which will provide precise statistical data in these matters and will cover all the courts. 


\section{Transparency in Monetary and Financial Policies}

\section{A. Transparency of Banking Regulation and Supervision}

\section{General}

267. This assessment of observance of the IMF's Code of Good Practices on Transparency in Monetary and Financial Policies (MFP) assesses the transparency of France's policies and practices in the area of banking regulation and supervision. The assessment is based on discussions with representatives of the relevant regulatory and supervisory agencies and with representatives of major banks, rating agencies and the accounting and auditing profession. It was further based on a pre-mission self-assessment prepared by the authorities; study of the relevant laws and regulations; a review of the annual reports, other publications and websites of the Banque de France (BdF), Commission Bancaire (CB) and Comité des Etablissements de Crédit et des Entreprises d'Investissement (CECEI); and an earlier assessment made by an IMF team in the context of the 2000 Article IV consultation.

268. The legal framework for banking regulation and supervision in France is defined by the Code Monétaire et Financier (Monetary and Financial Code). This code allocates different responsibilities to three main players: the $\mathrm{CB}$ for supervision, the CECEI for licensing, and the Minister in charge of the economy for regulation. In the current government set-up, the Ministry of Economy, Finance and Industry (MINEFI) handles regulation. Until earlier this year, this last function was performed by the Comite de la Réglementation Bancaire et Financière (CRBF). The CRBF has now been transformed in an advisory body, the Comité Consultatif de la Législation et de la Réglementation Financières (CCLRF), advising the MINEFI in drawing up bank legislation and regulations. The CB, CECEI, and CCLRF are set up as specialized agencies within the BdF group. They draw on the $\mathrm{BdF}$ for their staff and other resources and the Governor of the BdF is also president of the $\mathrm{CB}$ and the CECEI.

\section{Main findings}

269. France reaches a high level of transparency in its bank regulation and supervision policies and practices. Transparency is supported by a clear legal framework, a culture of extensive disclosure and consultation, and a range of informative publications.

270. The roles, responsibilities and objectives of the agencies involved in bank regulation and supervision are clearly defined, explained and disclosed. The Monetary and Financial Code lays down the broad objectives, responsibilities and authority of the CB, CECEI and MINEFI. These broad objectives cover in particular (i) building a system of prudential regulations addressing bank soundness and maintenance of fair and competitive markets; (ii) client asset protection; (iii) enforcement of applicable laws and regulations; and (iv) maintenance of market and systemic liquidity. Disclosure and explanation of these objectives, responsibilities and authority is effected through official publications such as the Journal Officiel de la République Française (JORF), the Bulletins of the CB and BdF, and 
the annual reports and websites of the different agencies. The Monetary and Financial Code - and to a lesser extent other legislation (including the constitution) — also outlines the broad modalities of accountability; the procedures for appointment, terms of office and general criteria for removal of the heads and members of the agencies' governing bodies; and the framework for the relationships between the different agencies.

271. There is a high degree of openness in the process of formulating and reporting banking regulation and supervision policies, thanks to a transparent and comprehensive consultation process. The regulatory framework is clearly set out in legislation and regulations, and disclosed/explained through the above-mentioned official publications and an annual compendium of laws, regulations, and directives applicable to the banking and financial sectors. The Monetary and Financial Code specifies the framework for cooperation and exchange of information between domestic agencies, and between domestic agencies and their foreign counterparts. The $\mathrm{CB}, \mathrm{CECEI}$ and $\mathrm{BdF}$ publish informative annual reports. Extensive consultations are held before substantive changes in legislation or regulations, and this consultation process benefits from the compulsory membership of all licensed banks and investment firms in a professional organization. This allows for comprehensive distribution of drafts to all market participants, but this is not always done consistently, creating the risk of deviations between the positions defended by the organization and the consensus view of its membership. Once fully operational, the new CCLRF will further enhance the consultation process.

272. Information on banking regulation and supervision is publicly available and easily accessible. The CB and CECEI both publish an annual report that describes major developments in the banking and financial sectors - seen from their respective angles of responsibility - and reports aggregate data. The $\mathrm{CB}$ also publishes a semiannual Bulletin and an annual comparative analysis, which provide further information and data on banking sector developments. The BdF provides reports on a quarterly and annual basis and a Financial Stability Review. All these publications are available online on the websites of the $\mathrm{BdF}$ and $\mathrm{CB}$. The CB, CECEI and CCLRF use the BdF's Communications Divisions to provide public information services. The Governor of the BdF (including in his capacity as president of the CB and the CECEI) and senior officials of the CB's General Secretariat explain their agencies' objectives and performance at parliamentary hearings and through public speeches. Texts of regulations are made available through the agencies' websites and publications, the compendium and other French government information services (such as www.legifrance.gouv.fr). None of the three financial agencies engaged in banking supervision and regulation provide emergency financial support to supervised institutions, although support operations can be undertaken by the BdF.

273. Transparent mechanisms for accountability and assurances of integrity exist for the different bank supervision agencies. The Governor of the $\mathrm{BdF}$ is required to issue an annual report to the President of the Republic and to Parliament, and must appear before the Finance Commissions of the National Assembly or the Senate if so requested, or if the Governor wishes to be heard by these bodies. These provisions also apply to his functions as Chairman of the CECEI and the CB. Assurance of the integrity of operations of the banking supervisory 
agencies rests with l'Inspection Générale of the BdF. The existence and mission statement of the Inspection Générale is stated on the organization chart of the BdF. Internal standards for the conduct of personal financial affairs are set out in the BdF's Code de déontologie financière which is published in the Official Bulletin of the BdF. A recent internal but published rule complementing the Code de déontologie financière focuses more specifically on good practices to be applied by officials and staff when they are offered gifts in the conduct of their official duties. CB staff is adequately protected by the general principles of administrative law applicable to persons in charge of a public function, and the relevant essential judicial rulings are widely publicized and discussed in the legal press. Nevertheless, a form of disclosure and clarification of these rules that is more accessible to the general public would be helpful.

Table 8. Recommended Action Plan to Improve Observance of IMF's MFP Transparency Code Practices_-Banking Supervision

\begin{tabular}{|l|l|}
\hline Reference Principle & Recommended Action \\
\hline None. & \\
\hline
\end{tabular}

\section{Authorities' response}

274. The authorities are in broad agreement with the assessment.

\section{B. Transparency of Deposit Insurance}

\section{General}

275. This assessment of observance of the IMF's Code of Good Practices on Transparency in Monetary and Financial Policies assesses the transparency of France's deposit insurance policies and practices, as implemented by the French deposit insurance agency, the Fonds de Garantie des Dépôts (FGD). The assessment is based on discussions held with the director of the FGD, other representatives of regulatory and supervisory agencies in France, and representatives of the major banks. It was further based on a pre-mission self-assessment prepared by the authorities; study of the relevant laws and regulations; a review of the FGD's website; and an earlier assessment made by an IMF team in the context of the 2000 Article IV consultation.

276. The FGD was established by the Savings and Financial Security Act of June 25, 1999, which was subsequently transposed into the Monetary and Financial Code. This basic legal framework is complemented by two decrees, as well as by a series of regulations issued by the CRBF. The FGD is set up as a special purpose legal entity under private law, of which all credit institutions licensed in France must be members. It is overseen by a supervisory council composed of representatives of the member credit institutions. On a day-to-day basis, the FGD is managed by a board consisting of three directors, one of which is designated President. The directors and President are nominated by 
the supervisory council, but the nomination of the President is subject to MINEFI approval. The FGD covers bank deposits, certain securities, and a specific type of bank guarantees (cautions) that some professions in France must obtain. The limit of its coverage is set at EUR 70,000 per individual per bank. In addition, it can preventatively intervene in a financial institution at the request of the $\mathrm{CB}$.

\section{Main findings}

277. Although many aspects of the deposit insurance system in France are very transparent, the assessment reveals that in several areas, significant scope for improvement exists. In particular, the observance of the MFP Transparency Code could be improved through the following actions: (i) the publication of an annual report by the FGD, including audited financial statements; (ii) more proactive use of the FGD's authority to explain its functioning to the public; and (iii) clarification of the legal protection of officials of the FGD.

278. The main objectives of the FGD are clearly laid out in the Monetary and Financial Code, as being to reimburse the clients of financial institutions when (i) their deposits become unavailable, (ii) certain securities become unavailable, or (iii) a financial institution is unable to honor the cautions it has granted. The Monetary and Financial Code, appurtenant decrees and regulations and the FGD's own (publicly disclosed) internal rules define the basic institutional framework of the FGD; its concrete responsibilities; its broad modalities of accountability; the procedures for appointment and removal, and the terms of office, of the members of its supervisory council; and its relationships with other financial agencies. All of this is further explained on the website of the FGD.

279. There is scope for greater openness in the process for the formulation and reporting of deposit insurance policy. The FGD's regulatory framework and operating procedures are publicly disclosed and explained in the Monetary and Financial Code and appurtenant regulations and decrees, as well as on the FGD's website. This is also the case for its funding arrangements. The Monetary and Financial Code also outlines the basic framework for information sharing between the FGD and other financial agencies, and allows the FGD to conclude agreements with foreign counterparts, but it does not prescribe whether or not such agreements must be publicly disclosed. Significant changes in deposit insurance policy are subject to the transparent consultation and disclosure practices that apply to all laws and financial sector regulations in France. However, there is insufficient transparency towards depositors on the fact that branches and subsidiaries of foreign banks in France may not have the same level of coverage as domestic institutions. Furthermore, an important factor impeding transparency is the absence of an annual report published by the FGD. While the FGD website is very informative, it is not a substitute for a periodic report.

280. While in some respects, the public availability of information on deposit insurance policy is very good, overall it suffers from the absence of an FGD annual report and of a proactive communications policy. In part because it does not publish an annual report, the FGD does not disclose aggregate data on areas related to its jurisdictional responsibilities or its financial activities. The FGD prepares audited annual financial statements, which are 
audited by two different auditors and presented to the Minister in charge of economic affairs, but these statements are not publicly disclosed. Apart from its very informative website, the FGD has no public information services and, thus far, its senior officials have not felt the need to explain their policy objectives and performance to the public in any way other than through the website. All legal provisions, regulations and instructions relative to the functioning of the FGD are readily available to the public, through publication in the Monetary and Financial Code, the Recueil de Textes Reglementaires of the CRBF, the JORF, the websites of the FGD and the BdF, and www.legifrance.gouv.fr .

281. There is also significant scope for improvement of transparency in the area of accountability and assurances of integrity by the FGD. There are no rules prohibiting or providing for the appearance of FGD officials before designated authorities to publicly report on the FGD's activities, objectives and performance. There is also no track record of officials doing so, in part because thus far no perceived need has arisen. The FGD produces audited financial statements, but these are only reported to the MINEFI and not publicly disclosed. The decisions of the FGD can be challenged before an administrative judicial authority. There are no specific rules of conduct on separation of private financial matters of officials and staff of the FGD from those of the FGD itself, nor on avoidance of conflict of interest, abuse of insider information and similar rules. There is no specific legal protection for officials of the FGD personally. However, under French administrative law, suits must be brought against the legal entity, not against the individual managers or officials.

Table 9. Recommended Plan of Action to Improve Observance of IMF's MFP Transparency Code Practices-Deposit Insurance

\begin{tabular}{|c|c|}
\hline Reference Principle & Recommended Action \\
\hline \multicolumn{2}{|c|}{ VI. Open Process for Formulating and Reporting of Financial Policies } \\
\hline 6.1 .1 & $\begin{array}{l}\text { Increase transparency on the fact that deposits in branches and subsidiaries of foreign } \\
\text { banks in France may not have the same level of coverage as domestic institutions. }\end{array}$ \\
\hline 6.1 .5 & $\begin{array}{l}\text { Disclose the formal procedures for information sharing between the FGD and } \\
\text { domestic and international financial agencies in greater detail. }\end{array}$ \\
\hline 6.3 & $\begin{array}{l}\text { The FGD should issue a periodic public report that provides an update on how its } \\
\text { policy objectives are being pursued. }\end{array}$ \\
\hline \multicolumn{2}{|c|}{ VII. Public Availability of Information on Financial Policies } \\
\hline 7.2 & Periodically publish aggregate data on the FGD's operations. \\
\hline 7.3 and 7.3.1 & $\begin{array}{l}\text { Publicly disclose the FGD's balance sheet on a pre-announced schedule, as well as a } \\
\text { report on its market operations and, after an appropriate delay, aggregate information } \\
\text { on any emergency financial support by the FGD to financial institutions. }\end{array}$ \\
\hline 7.4, 7.4.1 and 7.4.2 & $\begin{array}{l}\text { The FGD should establish a publications program and a more proactive policy for } \\
\text { public communication by its senior officials. }\end{array}$ \\
\hline
\end{tabular}




\begin{tabular}{|l|l|}
\hline Reference Principle & \multicolumn{1}{c|}{ Recommended Action } \\
\hline 8.1 & $\begin{array}{l}\text { Establish a policy or practice on the appearance of FGD officials before a designated } \\
\text { public authority to report on the conduct of the FGD's policies, explain its policy } \\
\text { objectives and describe its performance. }\end{array}$ \\
\hline 8.2 and 8.3 & $\begin{array}{l}\text { Publicly disclose the FGD's audited accounts, including its operating expenses and } \\
\text { revenues, on a pre-announced schedule and at least annually. }\end{array}$ \\
\hline 8.4 .1 & $\begin{array}{l}\text { Clarify and publicly disclose the existing legal arrangements governing the protection } \\
\text { of officials and staff of the FGD. }\end{array}$ \\
\hline
\end{tabular}

\section{Authorities' response}

282. The authorities are broadly in agreement with the assessment.

\section{Transparency of Insurance Regulation and Supervision}

\section{General}

283. This assessment examines France's observance of the IMF's MFP Transparency Code in the area of insurance supervision. The assessment is based on discussions with the French authorities during the FSAP missions that visited Paris in January-February and May 2004. It is further based on a review of the website of the Commission de Contrôle des Assurances, Mutuelles et des Institutions de Prévoyance (CCAMIP) and its predecessor's (the CCA) most recent annual report, relevant laws and regulations, and other publications. It was also based on an earlier assessment performed in 2000 by an IMF team (see www.imf.org).

284. Insurance regulation and supervision in France was significantly reformed by the August 2003 Financial Security Law. Formerly, insurance supervision was divided between two agencies - the CCA for insurers governed by the Code des Assurances (Insurance Code), and the Commission de Contrôle des Mutuelles et des Institutions de Prévoyance (CCMIP) for mutual and provident insurers, dependent respectively from the Ministry of Finance and the Ministry of Social Affairs. The Financial Security Law merged those two agencies into a single autonomous insurance supervisor, the CCAMIP. Insurance regulation remains the responsibility of the Ministry of Finance.

285. Insurance regulation and supervision in France is governed by the Insurance Code, the Mutuality Code (Code de la Mutualité) and the Social Security Code (Code de la Sécurité Sociale), as amended by the Financial Security Law, and by accompanying regulations. These three codes contain the same provisions on prudential matters, applied to different types of institutions. 


\section{Main findings}

286. Insurance supervision in France has achieved a high level of transparency, and the reforms put in motion by the 2003 Financial Security Law have especially improved the transparency of supervision of mutual and provident institutions, by harmonizing their prudential framework with that of the insurance companies governed by the Insurance Code. Nevertheless, the assessment identified a number of areas where improvements are possible. In most if these areas, the transparency problems found are related to the ongoing institutional transition, as well as to a general insufficiency of resources, which the CCAMIP expects to be able to address.

287. The role, responsibilities and objectives of the CCAMIP are clearly specified in the Insurance Code, as are the roles of other agencies involved in insurance regulation and supervision, notably the MINEFI, the Comité des Entreprises d'Assurance (CEA), which is responsible for licensing insurance companies and the Comité consultatif de la législation et de la réglementation financières (CCLRF). The CCAMIP's objectives are (i) the protection of policyholders and (ii) the enforcement of relevant laws and regulations. The broad modalities of accountability and the main governance provisions for the CCAMIP are also specified in the Insurance Code. The relationships between the CCAMIP and other agencies are provided for in the Insurance Code and are disclosed and explained in the CCAMIP's annual report and on its website.

288. Open processes exist for the formulation and reporting of the CCAMIP's policies. The CCAMIP's regulatory framework, operating procedures, regulations and fee structure are disclosed in the Insurance Code and appurtenant texts. Policies are further explained and reported in an annual report. A two-round consultation process exists for proposed substantive technical changes to the structure of insurance regulation. Information on the formal procedures for information sharing and consultation between the CCAMIP and other financial agencies is publicly available on the former's website.

289. Information on the CCAMIP's policies and on the insurance market is made available to the public through its annual report, other publications and its website. The CCAMIP intends to publish its financial accounts, but the practical modalities for doing so have not yet been established. The CCAMIP has not yet published an annual report. As a result of a lack of resources and the ongoing institutional reform, its predecessor (the CCA) only published two reports during the past four years, covering two years each (2000-2001 and 2002-2003).

290. While the Insurance Code and the envisaged functioning of the CCAMIP aim for a high level of accountability and assurances of integrity, in the current transitional phase, there is significant scope for improvement. Officials of the CCAMIP stand ready to appear before a designated public body to report on the conduct of insurance supervision. The CCAMIP intends to disclose its financial statements, but the practical modalities for doing so have not yet been determined. The financial accounts will be audited by the Cour des Comptes, but at its discretion and not necessarily annually. At present, the CCAMIP's internal governance procedures are not publicly disclosed. General standards for the conduct 
of personal financial affairs of civil servants are specified in the general statute of the French civil service. A specific Code of Conduct (Code de Déontologie) for CCAMIP staff was approved in July 2004, and is publicly disclosed on the CCAMIP's website. The legal protections for officials and staff of the CCAMIP are clearly specified in the law.

\section{Table 10. Recommended Action Plan to Improve Observance of IMF's MFP Transparency} Code Practices-Insurance Supervision

\begin{tabular}{|l|l|}
\hline Reference Practice & \multicolumn{1}{|c|}{ Recommended Action } \\
\hline VI. Open Process for Formulating and Reporting of Financial Policies \\
\hline 6.3 & \multicolumn{1}{|c|}{ The annual report should be published every year, on schedule. } \\
\hline VII. Public Availability of Information on Financial Policies
\end{tabular}

\section{Authorities' response}

291. The CCA's report for the years 2002 and 2003 has been endorsed by the board, and is to be published.

292. 8.2.2. The respective roles of the board and the Secretary General are defined by the law (L.310-12-1). More detailed rules will be specified in the decrees establishing the CCAMIP, to be published soon.

293. The CCAMIP's financial accounts will be established according to general accounting rules, by an accounting agent, who will not have any hierarchical link with the CCAMIP staff and cannot be given any order by the CCAMIP management. These financial accounts will be verified by the Cour des Comptes according to rules that are applicable to all administrative institutions. 


\section{Transparency of Securities Regulation and Supervision}

\section{General}

294. This assessment of observance of the IMF's Code of Good Practices on Transparency in Monetary and Financial Policies assesses the transparency of the role of the Autorite des Marchés Financiers (AMF) within the framework for securities regulation and supervision in France. It is based on discussions with representatives of the AMF that took place during the FSAP missions to Paris in January-February 2004 and May 2004. It was further based on a review of the relevant legislation and regulations, diverse publications, the AMF's website (www.amf-france.org), and an earlier assessment made by an IMF team in the context of the 2000 Article IV consultation.

295. The assessment took place in a context of transition. The August 2003 Loi de Sécurité Financière (Financial Security Law) significantly reformed the framework for securities regulation and supervision in France, in part by merging three existing agencies, the Commission des Opérations en Bourse (COB), the Conseil des Marchés Financiers (CMF), and the Conseil de Discipline de la Gestion Financière (CDGF) into a single new agency, the AMF. The implementation of this merger was still ongoing at the time of the FSAP missions. For this assessment, where there was an insufficiently long track record of practices at the AMF: it was assumed that good transparency practices of the former agencies would be maintained, while taking into account the changed regulatory and legal framework.

296. Securities regulation and supervision in France is governed by the Monetary and Financial Code, as modified by the Financial Security Law of August 1, 2003. The law gives the AMF responsibility for ensuring the protection of public savings invested in financial instruments and gives it the authority to issue regulations and to supervise issuers and markets. The CB, the CECEI and the BdF are also involved in securities oversight, although to a lesser extent than the AMF.

\section{Main findings}

297. The AMF reaches a high degree of transparency in its policies and functioning. The few areas for improvement that the assessment identified are in part related to the current transitional state and further improvements are expected as the AMF overcomes its start-up challenges. In this context, the recommendations outlined in Table 1 are meant to further enhance what is already a highly transparent situation.

298. The AMF's roles, responsibilities and objectives are clearly defined and publicized in the Monetary and Financial Code, as amended by the Financial Security Law. The law also clearly sets out the responsibilities of other agencies involved in securities regulation and supervision. It further prescribes the AMF's broad modalities of accountability, its main governance provisions, the framework for its relationships with other domestic and foreign agencies, and its role in payment and settlement systems. The AMF's website and publications provide additional information and explanation on its roles, responsibilities and objectives. 
299. An open process is in place for the formulation and reporting of the AMF's regulatory and supervisory policies. The conduct of its policies is transparent, governed by publicly disclosed laws, regulations and operating procedures. Nevertheless, transparency could be further enhanced by bringing these documents together in a single reference text. The AMF also issues an annual report that discusses how its policy objectives are being pursued. For proposed substantive technical changes to the structure of securities markets regulations, consultations are routinely held with market participants and working groups of experts, although the AMF is not publicly committed to such consultations.

300. Comprehensive information on securities regulation and supervision is made publicly available through the annual report of the AMF, the publication of quarterly statistics, and broader public information services, as well as through the AMF's highly informative website. Information on the asset protection scheme and consumer protection arrangements the AMF oversees is publicly available in the relevant laws and regulations, and further elaborated on the websites of the BdF and the AMF respectively.

301. The AMF reaches a high degree of transparency in its accountability and assurances of integrity, but further enhancements are possible. AMF officials are available to appear before the Commissions of Finance of both chambers of parliament. The AMF's accounts are produced by an independent accountant and audited by the Cour des Comptes. However, these audits take place at the discretion of the Cour des Comptes, rather than on a regular basis, and the results of the audits are not published along with the financial statements. Some of the modalities for the publication of the AMF's annual report remain to be determined. The AMF's internal governance procedures and its internal audit division are not yet fully in place and hence not fully disclosed, although the framework for them is foreseen in the law.

Table 11. Recommended Action Plan to Improve Observance of IMF's MFP Transparency Code Practices-Securities Regulation and Supervision

\begin{tabular}{|c|c|}
\hline Reference Principle & Recommended Action \\
\hline \multicolumn{2}{|c|}{ VIII. Accountability and Assurance of Integrity by Financial Agencies } \\
\hline $\begin{array}{l}\text { Public disclosure of audited financial statements } \\
(8.2 \text { and } 8.2 .1)\end{array}$ & $\begin{array}{l}\text { Have the AMF's financial statements audited at least } \\
\text { annually, rather than on an occasional basis. Publish the } \\
\text { audited financial statements fully, on a pre-announced } \\
\text { schedule. Include the accounting policies and any } \\
\text { qualifications to the statements as an integral part of these } \\
\text { publicly disclosed financial statements }\end{array}$ \\
\hline $\begin{array}{l}\text { Disclosure of internal governance procedures } \\
(8.2 .2)\end{array}$ & $\begin{array}{l}\text { Elaborate and publicly disclose the AMF's internal } \\
\text { governance procedures, and make them operational. }\end{array}$ \\
\hline
\end{tabular}




\section{Authorities' response}

302. The AMF notes that its financial statements are subject to several statutory mechanisms of accountability to the President of the Republic, to the Parliament and its commissions of finance, a special investigative committee that can be convened by the Parliament, and a routine basis accountability to the Cour des Comptes. The transmission of the financial statements to the latter is made yearly and the justifying documents are kept at its disposal for ten years. Those can be audited at any time by the Cour des Comptes and any practice that is not compliant with the principle of good governance shall be made public in its annual report. Moreover, it should be noted that the IOSCO principles and methodology, although defining clear accountability and transparency criteria, do not go as far as to require an external auditor to audit the regulator's account annually and to publish the findings of this audit on a pre-announced schedule.

303. The AMF notes that under this principle relating to internal governance, several interrelating issues seem to have to be taken into consideration. These include provisions on the governance of staff and members of the Board on conflict of interests, but might also encompass questions related to the integrity of the decision making process as a whole and the integrity of the internal procedure mainly of operational areas. In this regard, as noted by the experts in their conclusion, the AMF is in the process of hiring an internal control officer and his deputy and will therefore soon be able to comply with the requirements set forth under this principle, although it is worth noting that this new internal control division will only add an independent level of control on procedures already set up by the management of the AMF accountable to the Secretary General.

\section{E. Transparency of Payment Systems Oversight}

\section{General}

304. This assessment examines France's observance of the IMF's MFP Transparency Code in the area of the payment systems oversight exercised by the BdF, including the oversight of Securities Clearing and Settlement Systems (SCSS). The assessment is based on discussions with the French authorities during the FSAP missions that visited Paris in January-February and May 2004. It is further based on a review of the website of the BdF, the BdF's most recent annual reports, relevant laws and regulations, and other publications. It is also based on an earlier assessment performed in 2000 by an IMF team (see www.imf.org).

305. Payment systems oversight and the oversight of securities settlement systems in France are based on a legal and regulatory framework established at the European level, by the European Central Bank (ECB) and the ESCB, as well as on the French Monetary and Financial Code. It encompasses France's contribution to the oversight of pan-European systems such as the Trans-European Automated Real-time Gross settlement Express Transfer system (TARGET), Clearnet and the Euroclear group, as well as the oversight of purely 
domestic systems such as Paris Net Settlement System (PNS) and Système Interbancaire de Télécommunications (SIT), for which the BdF bears sole responsibility.

\section{Main findings}

306. The BdF achieves a high level of transparency in its payment systems oversight function, although further improvements are possible. This is especially the case regarding openness of the processes for the formulation and reporting of payment systems oversight policies.

307. The role, responsibilities and objectives of the BdF in the oversight of payment systems and securities settlement systems are clearly specified in the Monetary and Financial Code, and in treaties, protocols and other legal texts at the European level. They are further disclosed and explained in the BdF's annual report and other publications, on its website, and during presentations by BdF officials. The broad modalities of accountability for the BdF, as well as its main governance provisions, are also specified in the Monetary and Financial Code. The relationships between the $\mathrm{BdF}$ and other agencies, domestic as well as foreign, are disclosed in legislation, treaties and other publications. The BdF encourages the timely public disclosure of general policy principles by the operators of payment systems through its promotion of applicable international standards.

308. Open processes exist for the formulation and reporting of the BdF's policies in the area of payment systems oversight, but significant improvements are possible. The BdF discloses and explains the regulatory framework for payment systems oversight, but there is currently no publicly disclosed overall set of operating procedures in place governing the conduct of this oversight. Financial reporting by payment systems operators is governed by undisclosed bilateral agreements. The framework for information sharing and consultation is publicly disclosed, but detailed formal procedures are only partially disclosed. Significant changes in oversight policy are publicly announced and explained, and public consultations are systematically organized in case of substantive technical changes to the structure of financial regulations. The BdF reports on its payment systems oversight function in reports to the legislature, its official bulletin and its annual report, as well as on its website.

309. Information on payment systems oversight is made publicly available in various ways. The BdF reports on major developments in payment and settlement systems in its annual reports, on its website and in its bulletin. The BdF also maintains extensive public information services and a publications program, both of which cover payment systems oversight issues as well as the BdF's other functions. A specific section of the BdF's website deals with payment systems issues. Regulations and other generally applicable directives and guidelines are available through official websites and publications. Senior officials of the BdF stand ready to explain its payment systems policies in public fora and through other channels.

310. The BdF's accountability and integrity are assured, through provisions covering the $\mathrm{BdF}$ as a whole. As the BdF's department responsible for payment systems is not an 
independent entity, it is covered by these provisions and there are no additional specific mechanisms for accountability and integrity in the domain of payment systems oversight. The Governor of the BdF can be asked, or ask, to appear before parliament. Internal governance procedures, standards for the conduct of personal financial affairs of BdF officials and staff, and information on legal protections are publicly disclosed, through laws and/or other published documents.

Table 12. Recommended Action Plan to Improve Observance of IMF's MFP Transparency Code Practices-Payment systems oversight

\begin{tabular}{|l|l|}
\hline Reference Practice & \multicolumn{1}{c|}{ Recommended Action } \\
\hline VI. Open Process for Formulating and Reporting of Financial Policies \\
\hline 6.1 .1 & $\begin{array}{l}\text { Clearly specify, publicly disclose and explain the operating procedures governing the } \\
\text { conduct of the BdF's payment systems oversight function. } \\
\text { Improve efforts to explain and clarify international standards and the way they should be } \\
\text { implemented in the French context by the different payment systems operators. }\end{array}$ \\
\hline 6.1 .5 & Disclose the formal procedures for information sharing and consultation in greater detail. \\
\hline
\end{tabular}

\section{Authorities' response}

311. The Banque de France welcomes the IMF's assessment that it reaches a very high level of transparency in its payment systems oversight function. It also takes good note of the recommendations above to further improve its observance of the IMF's MFP Transparency Code Practices. 


\section{STruCture AND Evolution OF THE French FinAnCIAL SySTEM}

312. The French financial sector is one of the largest and most sophisticated in the world. It is dominated by the banking sector, (64 percent of total financial assets in 2003) which has close links with other financial institutions (notably life insurance companies) and extensive foreign operations (Table 2). Other important financial sectors include insurance (and especially life insurance, which serves as a vehicle for retirement savings), and the markets for equity and public debt. Corporate bonds, pension funds, and reinsurance are of lesser importance. The sector is well integrated into the global and European financial system, and its structure and operations are strongly influenced by the various EU financial sector directives and the implementation of the EMU in 1999.

\section{Banking sector}

313. Since the mid-1980s, the banking system has gone through rapid structural changes. It was largely liberalized, and three waves of privatizations (in 1986-87, 1993-94, and 1997-99) have now mostly completed the state's withdrawal from bank ownership. However, the strains generated along the way contributed to the 1993-94 banking crisis, when the collapse of a real estate boom and macroeconomic pressures came together to affect some major banks, some of which were rescued with public funds.

314. The authorities have encouraged the emergence of a limited number of large, vertically integrated banking groups controlled by French shareholders, both to improve the stability of the system and to foster national champions. This has contributed to the emergence of six major banking groups, which control three quarters of the market; the largest group constitutes about one third of the sector. As in most industrialized economies, foreign-owned banks mostly operate in niche markets. However, in recent years, one medium-size commercial bank was taken over by a foreign bank. Another category of creditgranting institution, the "sociétés financières," is numerous but manages a relatively small volume of assets. Their activities are limited, and they cannot accept short-term deposits.

315. An important feature of the current structure of the banking sector is the prevalence of mutual groups: four of the six dominant banking groups (including the largest group) are organized on a mutual basis. Each has a central body that provides overall management and determines a commercial strategy for the group. The members of each group are linked through solidarity systems that effectively pool the solvency and liquidity within a group. To avoid moral hazard, the solidarity system relies on the central body's power to regulate and supervise the members of the group. ${ }^{25}$ Typically, these groups have created or acquired commercial corporate affiliates, some of which are quoted on the stock exchange. This has

${ }^{25}$ The central body's regulatory and supervisory powers are in addition to those of the CB, which are the same across banks. 
allowed them to raise funds on capital markets to finance expansion and acquisitions and increase the range of financial services they offer. The stock market listing has also strengthened the governance of these institutions by allowing large institutional investors to acquire stakes and requiring conformity with information disclosure standards for listed companies.

316. A few government-owned institutions remain. La Poste collects about 8 percent of bank deposits in France through its numerous branches, and is expanding its lending activities (Box 3). The CDC, which earlier this year agreed to merge its commercial activities with the Caisses d'Épargne, is mainly engaged in managing certain specific funds, including a large part of the savings collected through government-regulated savings schemes. It also holds stakes in a number of companies and financially supports government policies. The Ministry of Finance is responsible for La Poste, whereas parliament has oversight over the CDC. Both are audited by the government audit office, but are currently not subject to prudential supervision.

317. The government continues to influence the mobilization and allocation of savings through various schemes, in part directly and in part by altering the risk-reward trade-off of different savings alternatives. These schemes encompass certain controls on interest rates and fees, the design by the government of various savings products, the centralization of about a quarter of bank deposits in a fund managed by the CDC, restrictions on the use of funds collected through some savings products, and significant differences in tax treatment between financial products (Box 4). About 80 percent of bank deposits (including checking accounts) are subject to significant product and/or price prescriptions, and differences in tax treatment have steered household savings towards life insurance products and saving for house purchases.

318. These schemes tend to compress the banks' interest margins, while the popularity of the PEL has provided banks with abundant resources that they can invest only in specific uses (mortgage loans, mortgage-backed securities, and loans for investments in energy-saving projects). They have adapted to this context by using aggressively priced mortgage loans ${ }^{26}$ to attract long-term customers, while relying for their profitability on cross sales of high-margin products (e.g., mortgage insurance) as well as on fees and commissions.

319. Interbank lending and borrowing, including repo operations, constitute about a third of banks' balance sheets; on an aggregate basis, commercial banks are net borrowers, while mutuals are net lenders. Most interbank transactions are unsecuritized, but repo operations have increased in recent years to about a third of the total. This market has now become

\footnotetext{
${ }^{26}$ Mortgage rates in France are consistently below those in the rest of the euro area. In January 2004, for example, the average mortgage rate in France was 21 basis points lower than the euro area average. There have even been instances when mortgage rates were at or below long-term government bond rates.
} 
integrated across the euro area, although French banks still deal predominantly with each other.

\section{Box 4. Taxation and the Allocation of Savings}

Because the tax treatment varies significantly across savings instruments, tax minimization is a very important consideration in French savers' portfolio allocations. In general, interest income is subject to a 10 percent social charge, as well as to the regular income tax. However, taxpayers can in most cases opt to pay a 15 percent tax that allows them to keep interest income out of their general taxable income, which in practice caps the maximum taxation of interest income at 25 percent. Dividend income is subject to the social charges and the regular income tax, with a general EUR1,220 exemption and after a correction, which is meant to compensate for the corporate tax paid by the disbursing company. This correction, the "avoir fiscal," which is put at 50 percent of the net dividend, is first added to the net dividend income, and subsequently subtracted from the taxes due. In case the subtraction leads to a negative figure, the taxpayer receives a return. However, because the "avoir fiscal" is a relatively complex system that discriminates against foreign (including non-French) companies, it will be phased out in 2005. Instead, dividends, whether from French or foreign sources, will be taxed at half the regular income tax rate, subject to a EUR1,220 exemption and a EUR75 tax credit.

However, there are numerous exemptions and exceptions to these basic tax rules. Among bank products, most of the administered savings schemes benefit from favorable tax treatment. Interest income from livrets A, bleu, ${ }^{1}$ and jeune, as well as from the Codevi and LEP, are totally exempt from taxes, while interest on the PEL and CEL are only subject to the 10 percent social charge. The PEL and CEL also benefit from interest subsidies. There are also various savings schemes that provide tax breaks for investments in shares, the most important of which is the PEA, which provides favorable tax treatment for up to EUR132,000 invested in shares.

Life insurance products, one of the most popular forms of long-term investment, offer relatively steady returns and still benefit from a favorable tax regime. Initially, income from life insurance policies was totally exempted from taxation after eight years and 25 percent of premiums paid (up to a limit) were tax-deductible. Since 1995, the French government scaled back the tax advantages through the progressive cancellation of the tax deduction for new premiums paid, the introduction of various taxes on life policy yields, and the imposition of inheritance tax for life policies above a threshold. Nevertheless, the tax regime of life insurance products remains attractive to policyholders. Life insurance products are not subject to either the value added tax, which does not apply to insurance products, or its substitute, the insurance tax; certain policies remain exempt from the inheritance duty; and regular premium payments benefit from partial income tax exemptions, as do most annuity retirement payouts. Furthermore, heavy tax penalties for early withdrawal ensure a relative stability to life insurance products.

In April 2004, the French authorities launched their first private retirement savings plan (the PERP). This product benefits from a favorable tax regime (regular premium payments are tax deductible up to 10 percent of net activity income with a maximum threshold) and provides (taxable) annuity payouts at retirement, as opposed to the more common lump-sum capital payout schemes.

${ }^{1}$ One third of the interest on the livret bleu is taxed, but the tax is paid by Crédit Mutuel. 


\section{Insurance}

320. In contrast to the banking sector, insurance is relatively fragmented, with 454 companies. In the case of life companies, over 60 percent of total life insurance premiums are collected through bank offices. Overall, however, distribution channels remain varied.

321. The 126 life insurance companies account for 83 percent of total insurance assets. A large share of life insurance products are vehicles for saving for retirement. ${ }^{27}$ This practice is promoted by certain tax advantages (Box 4). The most common contract, which represents over 60 percent of total life premium income, guarantees the accumulated principal and pays out a lump-sum benefit at the end of the policy term. The second largest type of contract is a unit-linked policy. Insurance companies are promoting unit-linked policies because they are subject to lower solvency requirements and offer higher margins, but traditional life insurance products remain popular as a "safe haven" in the context of the ageing of the population and uncertainties about state retirement schemes.

322. The French reinsurance sector is relatively small (33 companies accounting for 3 percent of sectoral assets). Rather, French non-life insurers purchase reinsurance from abroad, or rely on government-sponsored schemes, notably for natural disasters. Reinsurance coverage must be backed by the reinsurer's collateral. The authorities are introducing a detailed reporting system, which is designed to be more forward-looking and provide more information on future potential claims.

\section{Securities markets}

323. The French stock market is capitalized at roughly $\$ 1$ trillion, or 70 percent of GDP. However, trading is concentrated in a small set of stocks with the five (ten) most actively traded shares constituting 30 (47) percent of the annual trading volume. Non-residents hold about 36 percent by market value of listed French shares. Thus, like the financial system generally, international linkages are strong (Box 5).

324. French exchange-traded equities and derivatives markets have undergone a major restructuring since 2000, when the Paris Bourse (for equities) and the Matif and Monep (for futures and options respectively) united with the Dutch, Belgian, and later Portuguese exchanges to form Euronext. In 2002 the London-based derivatives exchange LIFFE was acquired. However, the local markets (Euronext Paris in the case of France) are legally distinct, and hence they are regulated by their respective local authorities. Although some trading efficiencies have been gained with the consolidation of the stock exchanges, payment and settlement systems across jurisdiction have seen little harmonization and thus trading costs (including back-office related costs) have not meaningfully declined, which has preserved some market separation.

${ }^{27}$ Dedicated pension funds are new and are as yet small. 
325. The government debt market is large. France has recently issued inflation-linked (IL) bonds, which in turn has helped trigger the issuance of other (euro area sovereign and non-sovereign) IL debt instruments and the creation of an inflation-linked swap market. The corporate bond market in France has grown substantially with the introduction of the Euro, but is still equivalent to only a small fraction of the government securities market and is dominated by financial sector issuers.

\section{Box 5. International Linkages}

Linkages between the French financial system and world markets are important and complex, but do not give rise to particular stability concerns. French banks undertake a large volume of interbank lending and borrowing with other European banks (the stock is currently about EUR400 billion), but counterparties have high credit ratings and much is done on a repo basis. Direct foreign lending by French banks and other claims on the foreign nonfinancial sector constitute about one tenth of their loan portfolio; most of these claims are on industrialized countries (claims by industrial country banks on French nonbanks are of comparable magnitude). Claims on developing and emerging markets are well diversified. Operations by foreign subsidiaries are not as extensive as those of banks from some other European countries and have a relatively strong retail orientation. However, claims on abroad and foreign operations are concentrated in a few institutions, notably the large commercial banks, one of which has recently acquired an extensive branch network in the U.S.

International exposure of insurance companies is moderate. Most cross-border activity takes place through subsidiaries of a few large companies: several of the top-tier companies in France are subsidiaries of foreign firms, and large French subsidiaries operate abroad (they earn about 30 percent of the sector's premium income). Direct foreign exposures (e.g., policies on properties in other countries) remain limited. It appears that French companies obtain a significant share of their reinsurance abroad (data are scarce), so difficulties at foreign reinsurers would raise costs.

Financial market prices are strongly correlated internationally. The interdependence is explainable by the increasing international diversification of investors' portfolios, and French companies' worldwide activities. Thus, French financial markets would be affected by booms and crashes in other major markets. The integration of the Bourse into Euronext has not greatly affected correlations between market movements.

326. After the changes to the Mortgage Bank Act in 1999, the covered bond market (bonds covered by mortgages and public sector loans, known as the Obligations Foncières) has grown to about EUR41 billion in bonds outstanding as of mid-2003. Since early 2003, their spreads have narrowed and fallen just below those of comparable German Pfandbriefe. However, the size of the Obligations Foncières market is still small relative to the stock of government securities, and its growth is expected to slow due to the limited supply of eligible mortgages and the number of issuers; the effects of the PEL; and (currently), high bank capitalization. The authorities have announced their intention to study reforms to the regulation of the mortgage market with a view to promoting "Obligations Foncières."

\section{Payment and securities settlement systems}

327. France has two systems for settling large value payments:

- Transferts Banque de France (TBF), a classic real-time gross settlement system that forms part of the TARGET framework of the European system of Central Banks and is 
the main channel for the executions of monetary operations and the settlement of ancillary systems for retail payments (SIT) and securities (Relit+); and

- Paris Net Settlement (PNS) system that is also a real-time system for the settlement of domestic large value payments. PNS differs from TBF in that sense that it allows participants to set sending limits on their counterparts and saves liquidity owing to optimization procedures that settle queued transactions simultaneously.

328. All retail payments instruments are cleared on one clearing platform (SIT) and settled in TBF. Retail payments - including checks - which are truncated, are fully dematerialized. Checks are still extensively used in France, although their share in retail payments is declining.

329. The infrastructure for securities settlement consists of:

- a Central Securities Depository (Euroclear France) that operates a trade-for-trade real-time gross settlement system and a deferred netting scheme; and

- a central counterparty (Clearnet LCH) that settles all securities and derivatives transactions conducted on the Euronext platform, as well as transactions in the over-the-counter market in France and abroad. 


\section{Stress Testing Procedures and Assumptions}

330. The stress tests performed as part of the France FSAP were designed to provide insight into the relative strength of the financial system should it face certain severe shocks judged to be plausible but unlikely. Stress testing is necessarily a partial equilibrium exercise, which ignores such phenomena as institutions' reactions to shocks, and which cannot be applied to hypothetical situations very different from the actual one. Nonetheless, the comprehensive range of tests presented here are suggestive.

331. The procedures followed make use of the sophisticated stress testing capacity of French financial institutions and the supervisory authorities, and are innovative in several regards. Thus, the results allow fully for the need to consolidate effects across financial groups that contain both banks and insurance companies. The effects of various shocks were not only estimated by the institutions themselves, but also were cross-checked against the aggregate results obtained by the authorities. The authorities also generated macroeconomic scenarios using econometric models. The level of detail of the estimates allowed to take into account effects on banks' risk-weighted assets, and the sensitivity of demand for life insurance products to yields on alternative investments.

332. The sample of institutions covered comprises much of the sectors. For banks, all six large banking groups and one medium-sized bank participated; these institutions represent 80 percent of banking sector assets. The sample of insurance companies included 13 life groups (of which 7 belong to banks) and 11 non-life groups, which together hold more than 75 percent of the total sector's liabilities.

333. Two types of shocks were identified and calibrated: immediate shocks to one or more risk factors, such as changes in market prices that are not explicitly motivated; and macroeconomic shocks, where changes in exogenous variables generate deviations from a baseline projection over a two-year horizon. The shocks are listed in Tables $6 \mathrm{a}$ and $6 \mathrm{~b}$. The set of shocks applied to the banking and insurance sectors differed somewhat because some tests were irrelevant to one or the other. ${ }^{28} 29$

\footnotetext{
${ }^{28}$ Under the macroeconomic scenarios, deviations in variables such as interest rates that are relevant to the insurance sector were within the bounds of the single factor stress tests. Shocks F3a and F3b (large sustained interest rate movements) could not reasonably be applied to banks under the assumption that they would not change their balance sheet. Neither shocks F10 (real estate price fall) nor F12 (natural disaster) would have a significant direct effect on the banks' balance sheets.

29 The authorities also undertook three separate stress tests for a deterioration in the quality of housing loans assuming: (i) a default of all NPLs related to floating rate mortgages; (ii) a sharp increase in the default probability of mortgage loan repayments; and (iii) a macroeconomic scenario in which interest rates rise by 300 basis points over two years.
} 
The calibration of all shocks reflected historical experience: the single factor shocks were equivalent to the largest one-month movements seen in the relevant variables over the past 25 years. ${ }^{30}$ The changes in exogenous variables reflected historical experience with large macroeconomic shocks, with allowance for judgment as to plausibility in current circumstances. ${ }^{31}$ The macroeconomic scenarios are summarized in the following table:

Summary of Macroeconomic Stress Testing Scenarios

(Annual percentage growth rates, averaged over 2004-2005)

\begin{tabular}{lccccc}
\hline & Baseline Scenario & Scenario M1 & Scenario M2 & Scenario M3 & Scenario M4 \\
\hline & & & \multicolumn{2}{c}{ (Deviation from baseline) } \\
Real GDP & 2.1 & -2.4 & -0.2 & -0.3 & -0.9 \\
Real household consumption & 1.9 & -0.7 & -0.3 & -0.3 & -- \\
Short-term interest rate (level) & 2.1 & -- & -- & 0.1 & -0.9 \\
Consumer prices & 1.2 & -1.4 & 0.5 & 0.4 & -2.2 \\
Credit to the private sector & 5.8 & -3.5 & -0.4 & -- & 2.3 \\
NPLs 1/ & 8.3 & 8.2 & 0.8 & -0.6 & \\
& & & & \\
\hline
\end{tabular}

Source: French authorities, and staff estimates.

1/ Cumulative growth through December 2005.

334. Banks estimated the revaluation effects of the single and multi-factor shocks on their end-2003 balance sheets. Both the commercial banks themselves and Commission Bancaire estimated the effects of the macroeconomic disturbances and test F3. In this, the Commission Bancaire relied on its internal models of the behavior of bank earnings, nonperforming loans, required capital, and sectoral credit quality.

335. The estimated impact of the shocks must be measured against some metric to be meaningful and comparable to results from other countries. For banks, the shocks are related to: (i) 2003 after-tax profits, where the impact was reduced by the marginal corporate income tax rate of 33 percent; (ii) banks' end-2003 risk-weighted capital adequacy ratios, not adjusted for taxes; and (iii) for relevant tests, risk-weighted capital adequacy calculated under

While the effects of such large changes cannot be projected with precision, the results suggest that the impact would be moderate. Even if combining all scenarios, the maximum impact will be a reduction of less than 2 percentage points of the average solvency ratio, which will remain well above the minimum requirement.

${ }^{30}$ For interest rate movements, only changes since the establishment of the EMU were considered.

${ }^{31}$ Scenario M3 relies on an estimated policy reaction function which may not be fully applicable to the case of a one-time oil price shock. 
Basel II-type rules, assuming that after-tax profits earned during the projection period are added to capital. ${ }^{32}{ }^{33}$ Institution-by-institution information was not provided in order to preserve confidentiality, but the statistics on the distribution of results indicate how widespread any impact might be.

336. The Commission Bancaire receives quarterly reports on banks' liquidity positions that in effect reflect a stress test: banks are required to maintain a ratio of liquid assets to liquid liabilities of over 100 percent, under the assumption that the liquidity of many assets is impaired. Therefore, summaries of these reports served as liquidity stress test results. In the past, some relatively large banks occasionally fell below the liquidity requirement for technical reasons, for example, related to accounting complications during mergers.

337. Insurance companies estimated both the immediate and the permanent effects of these shocks, again based on their end-2003 balance sheets, taking into account the provisions of insurance regulations and outstanding contracts - in particular, the scope to pass on fluctuations in earnings to policyholders, and the possibility that policyholders will cash in life contracts early if yields fall far enough. It is worth noting that the flow effect on new investments is minimal.

338. The insurance stress tests are presented relative to the metrics of: (i) the immediate impact on the solvency ratio; and, for life policies, (ii) the change in the payout rate on policies, that is, the impact passed on to policyholders allowing for policy provisions and regulations on required payouts. Where one or another constraint is binding, the shortfall is presented as a ratio of technical provisions (expected liabilities to policyholders).

\footnotetext{
${ }^{32}$ Risk weights depended not only on the mean expected loss, but also on the upper tail of the distribution of losses (so-called "unexpected losses"). Under the stress tests, both the mean and variance of the distribution of losses were affected, and therefore risk-weighted assets and the corresponding capital requirement tended to rise. Account was also taken of the increase in credit projected in the macroeconomic scenarios.

${ }^{33}$ The implication that no dividends are paid is compatible with the scenarios of difficult economic times.
} 


\section{EFFECTS OF SAVINGS SCHEMES AND OTHER GOVERNMENT INTERVENTION}

339. Government policies continue strongly to affect the composition and allocation of a large part of financial savings through numerous schemes to mobilize and direct savings and credit towards programs judged to be in the public interest. These schemes have numerous effects beyond their intended policy objectives, and their relevance to current priorities is not assured:

- the less well-off sections of society may benefit relatively little from the tax advantages of many administered savings products such as the livret A. ${ }^{34}$ Hence, the schemes achieve a poor cost-benefit ratio;

- the mobilized resources do not necessarily correspond to the needs of the sectors they are meant to finance. ${ }^{35}$ These interventions also limit the resources that financial institutions have available to finance other sectors of the economy;

- they distort competition by restricting the distribution of certain products to certain institutions;

- by design, products like the PEL can generate risks for financial institutions that are difficult to hedge;

- the schemes reduce the scope and incentives for financial institutions to compete. They also discourage other forms of innovation. For example, the availability of dedicated PEL resources is an important impediment to the development of a market for mortgage-backed securities in France;

- they interfere with the transmission of monetary policy, and thereby give rise to asymmetries in the EMU; and

- the usury rate rule (which caps the potential interest rate at $4 / 3$ of the average rate observed for a loan category) prevents certain higher-risk potential borrowers from obtaining credit.

\footnotetext{
${ }^{34}$ Much of the French population participates in these schemes. Since personal income tax starts at a relatively high level, only the well-to-do benefit from the income tax exemption.

${ }^{35}$ For example, there is no link between the resources collected through the livrets A and bleu and the needs of the social housing entities (HLMs) they are meant to finance. Also, while those resources can be withdrawn and carry adjustable interest rates, the HLMs' optimal financing is long-term (30+ years) and at fixed rates. The system has thus far worked because savings in livrets were stable and their volume far exceeded the financing needs of housing entities. However, the latter fact reinforces the conclusion that the system is inefficient.
} 
340. While many of these costs, especially those related to missed opportunities and reduced competition and innovation, are unquantifiable, some static costs to - and transfers between - the parties involved can be approximated. Thus (with all figures on an annual basis):

- $\quad$ The ni-ni rule, which prohibits the payment of interest on demand deposits as well as charges for checkbooks, implies a transfer from depositors to banks to the tune of about EUR1 billion at current (low) levels of interest rates, due to the non-remuneration of demand deposits. It also implies a net loss to society (paid in first instance by the banks) related to the overuse of checks relative to less costly payment instruments (notably electronic payments and internet banking).

- $\quad$ The centralization of deposits under the management of the CDC implies a lost (gross) intermediation margin for banks of about EUR3-4 billion, to the benefit mainly of the government and the three distributors of the livrets A and bleu. Social housing entities pay a lower interest rate, but assume on significant interest rate risk. And while the government earned about EUR500 million on the centralized funds in 2002, the counterpart of that is the potentially large contingent liability it has taken on by guaranteeing the system.

- The tax breaks on the livrets and on the PEL/CEL and the interest rate subsidy on the PEL/CEL constitute a transfer of about EUR4 billion from the government to those households that are able to use the tax advantages.

- $\quad$ The compression of the banks' interest rate spreads resulting from the interventions implies a net transfer from them to households and companies in the order of EUR2-5 billion, an amount which can vary as a function of the spread between the rate on the livret $\mathrm{A}$ and market rates. ${ }^{36}$

341. Overall, this static analysis indicates that the system generates significant gross and net transfers among institutions and sectors. It appears that the banks, especially those that are not allowed to distribute livrets A or bleu, bear most of the costs. As the integration of European financial markets progresses, these costs could increase, for example, because remunerated current accounts in other countries could attract funds from French banks. The analysis here does not take into account the possible allocative inefficiency of diverting resources to favored sectors and the consequent reduction in the rate of growth of potential output.

${ }^{36}$ Recent changes in the determination of the livret A rate may reduce this effect. 
Table 1. Selected Economic Indicators, 1999-2004

\begin{tabular}{|c|c|c|c|c|c|c|}
\hline & 1999 & 2000 & 2001 & 2002 & 2003 & $20041 /$ \\
\hline \multicolumn{7}{|l|}{ Real economy (change in percent) } \\
\hline Real GDP & 3.2 & 4.2 & 2.1 & 1.1 & 0.5 & 2.6 \\
\hline CPI (year average) & 0.6 & 1.8 & 1.8 & 1.9 & 2.2 & 2.3 \\
\hline Unemployment rate (in percent) & 10.7 & 9.3 & 8.5 & 8.9 & 9.4 & 9.4 \\
\hline Gross national savings (percent of GDP) & 22.5 & 22.4 & 22.1 & 20.6 & 19.3 & 19.4 \\
\hline Gross domestic investment (percent of GDP) & 19.6 & 21.0 & 20.5 & 19.6 & 19.0 & 19.9 \\
\hline \multicolumn{7}{|l|}{ Public finance (percent of GDP) 2/ } \\
\hline Central government balance & -2.6 & -2.5 & -2.3 & -3.9 & -4.0 & -3.1 \\
\hline General government balance & -1.8 & -1.4 & -1.6 & -3.3 & -4.1 & -3.4 \\
\hline General government gross debt & 58.5 & 57.1 & 56.8 & 58.7 & 63.7 & 64.4 \\
\hline \multicolumn{7}{|l|}{ Money and interest rates } \\
\hline M3 (end of year, percent change) 3/ & 5.3 & 4.3 & 10.9 & 6.6 & 6.4 & $\ldots$ \\
\hline Money market rate (in percent) 4/ & 3.0 & 4.4 & 4.3 & 3.3 & 2.3 & 2.1 \\
\hline Government bond yield (in percent) 5/ & 4.7 & 5.5 & 5.0 & 4.9 & 4.2 & 4.4 \\
\hline Deposit rate $6 /$ & 2.7 & 2.6 & 3.0 & 3.0 & 2.7 & 2.2 \\
\hline Prime lending rate & 6.3 & 7.1 & 6.6 & 6.6 & 6.6 & $\ldots$ \\
\hline \multicolumn{7}{|l|}{ Balance of payments (percent of GDP) } \\
\hline Trade balance & 1.2 & -0.3 & 0.3 & 0.5 & 0.1 & -0.9 \\
\hline Current account & 2.9 & 1.4 & 1.6 & 1.0 & 0.3 & -0.5 \\
\hline \multicolumn{7}{|l|}{ Exchange rates } \\
\hline Exchange rate regime & \multicolumn{6}{|c|}{ Participant in EMU } \\
\hline Euro per U.S. dollar (August 24, 2004) & & & & & & 1.21 \\
\hline Nominal effective rate $(2000=100) 7 /$ & 103.4 & 100.0 & 100.4 & 101.2 & 104.7 & 105.3 \\
\hline Real effective exchange rate $(2000=100) 7 /$ & 104.1 & 100.0 & 98.9 & 99.7 & 102.6 & 102.7 \\
\hline
\end{tabular}

Sources: Data provided by the authorities; and Fund staff estimates.

1/ Unless otherwise indicated, staff projections released in the World Economic Outlook in October 2004.

2/ Data for 2001-02 excludes the proceeds from the sale of UMTS licenses, which amount to about

0.1 percent of GDP.

3/ Data for France until 1998 and for the euro area from 1999 onwards.

4/ Data refer to the interbank rate. For 2004, data are as of July.

$5 /$ Average yield to maturity on public sector bonds with original maturities of more than five years. The figure for 2004 refers to July.

6/ Livret A rate. The figure for 2004 refers to July.

7/ Based on relative normalized unit labor costs in manufacturing. The figure for 2004 refers to July. 


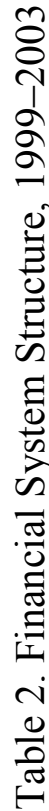

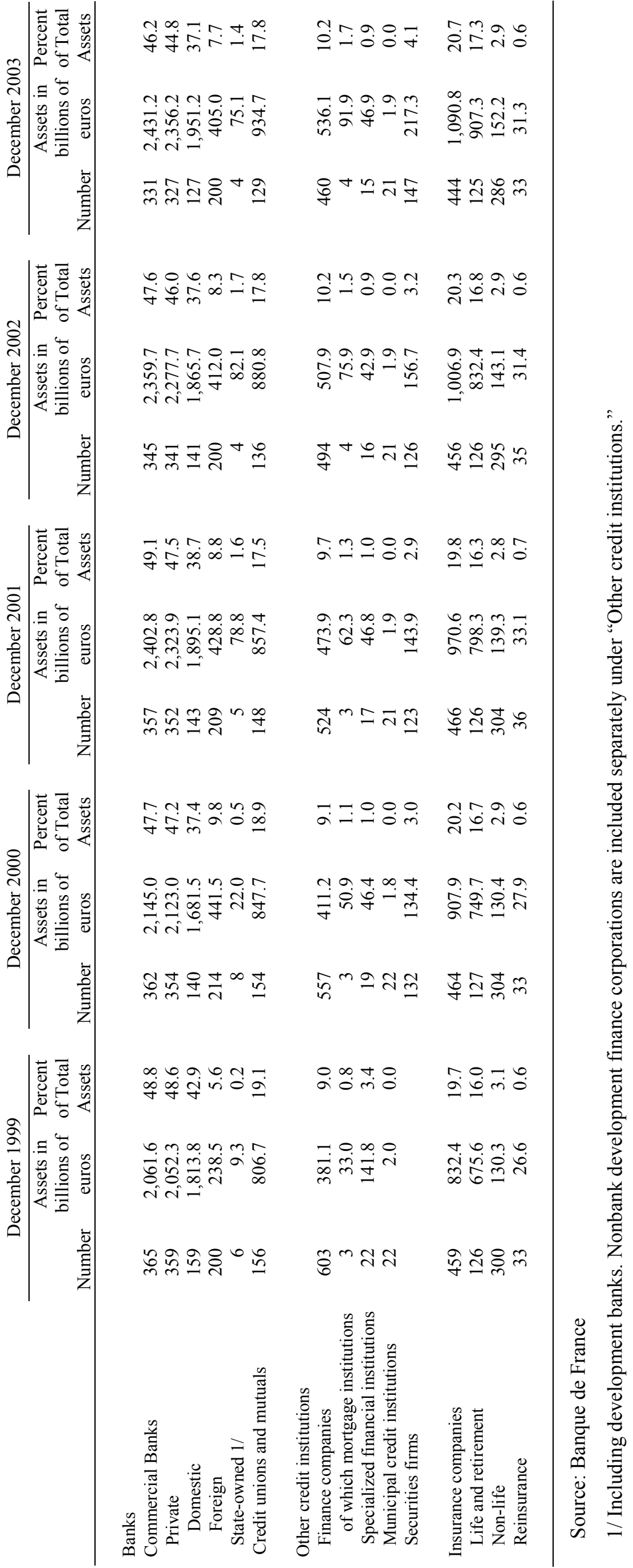


Table 3. Banking Sector: Financial Soundness Indicators, 1999-2003

(End of period; in percent, unless otherwise indicated)

\begin{tabular}{|c|c|c|c|c|c|}
\hline & 1999 & 2000 & 2001 & 2002 & 2003 \\
\hline \multicolumn{6}{|l|}{ Capital Adequacy } \\
\hline Regulatory capital to risk-weighted assets & 12.7 & 11.9 & 12.1 & 12.3 & 12.6 \\
\hline Regulatory Tier I capital to risk-weighted assets & 10.0 & 9.9 & 10.5 & 9.9 & 9.7 \\
\hline Capital (net worth) to assets & $\ldots$ & 4.6 & 4.8 & 4.6 & 4.5 \\
\hline \multicolumn{6}{|l|}{ Asset Composition and Quality } \\
\hline \multicolumn{6}{|l|}{ Sectoral distribution of loans to total loans, of which: } \\
\hline Deposit takers & 31.1 & 30.2 & 31.8 & 31.7 & 32.6 \\
\hline Non financial corporation & 19.6 & 21.0 & 19.7 & 19.9 & 19.1 \\
\hline Households (including individual firms) & 22.9 & 23.1 & 21.9 & 22.8 & 24.6 \\
\hline Non residents (including financial sectors) & 19.0 & 18.5 & 19.6 & 18.3 & 16.5 \\
\hline \multicolumn{6}{|c|}{$\begin{array}{l}\text { International consolidated claims of French banks, of which: } \\
\text { (BIS data, as percent of total international claims) }\end{array}$} \\
\hline Advanced countries & 77.0 & 79.0 & 81.0 & 84.0 & 85.0 \\
\hline Developing Europe & 2.0 & 2.0 & 2.0 & 2.0 & 2.7 \\
\hline Latin America and Caribbean & 4.0 & 3.0 & 3.0 & 2.0 & 1.4 \\
\hline Africa and Middle East & 4.0 & 4.0 & 4.0 & 4.0 & 3.3 \\
\hline Asia and Pacific Area & 5.0 & 4.0 & 3.0 & 3.0 & 2.7 \\
\hline Offshore Financial Centers & 8.0 & 8.0 & 7.0 & 5.0 & 4.5 \\
\hline Foreign currency loans to total loans $1 /$ & 14.9 & 15.1 & 15.3 & 12.6 & 11.2 \\
\hline NPLs to gross loans & 5.7 & 5.0 & 5.0 & 5.0 & 4.8 \\
\hline NPLs net of provisions to capital & 14.1 & 12.8 & 12.6 & 12.6 & 11.6 \\
\hline Large exposures to capital $2 /$ & $\ldots$ & $\ldots$ & $\ldots$ & 38.3 & 28.3 \\
\hline Gross notional outstanding financial derivatives/capital & 12,056 & 12,585 & 13,751 & 14,842 & 16,851 \\
\hline \multicolumn{6}{|l|}{ Earnings and Profitability } \\
\hline ROA (Aggregated data on a parent basis company) 3/ & 0.37 & 0.46 & 0.45 & 0.46 & 0.44 \\
\hline ROA (Main groups on a consolidated basis) 4/ & 0.49 & 0.53 & 0.40 & 0.39 & 0.45 \\
\hline ROE (Aggregated data on a parent basis company) 3/ & 9.08 & 9.69 & 9.64 & 9.08 & 8.62 \\
\hline ROE (Main groups on a consolidated basis) 4/ & 11.82 & 15.60 & 10.92 & 9.81 & 10.33 \\
\hline Interest margin to gross income & 40.8 & 36.6 & 35.9 & 40.2 & 39.2 \\
\hline Noninterest expenses to gross income & 67.6 & 67.7 & 66.9 & 65.5 & 65.5 \\
\hline Personnel expenses to noninterest expenses & 50.7 & 50.2 & 48.4 & 48.9 & 50.2 \\
\hline Trading and fee income to gross income & 40.0 & 42.9 & 41.2 & 36.2 & 34.9 \\
\hline \multicolumn{6}{|l|}{ Liquidity } \\
\hline Liquid assets to total assets & 19.6 & 19.5 & 20.4 & 20.7 & 21.6 \\
\hline Liquid assets to total short-term liabilities & 147.9 & 138.5 & 152.5 & 157.0 & 153.6 \\
\hline Customer deposits to total (non-interbank) loans & $\ldots$ & 88.8 & 89.9 & 88.7 & 89.3 \\
\hline FX liabilities to total liabilities & 15.7 & 17.3 & 18.4 & 15.1 & 14.1 \\
\hline Average daily turnover ratio in the securities market 5/ & 97.9 & 99.8 & 116.2 & 132.7 & $\ldots$ \\
\hline \multicolumn{6}{|l|}{ Sensitivity to Market Risk } \\
\hline Net open positions in foreign currency (euro millions) 6/ & $\ldots$ & 6,715 & 6,738 & 4,608 & 5,870 \\
\hline Net open positions in equities to Tier I capital & $\ldots$ & 3.93 & 2.94 & 3.30 & 2.27 \\
\hline
\end{tabular}

Sources: Banque de France, Commission Bancaire, BIS, and ECB.

1/ Data cover interbank and customer lending to residents and non-residents on a metropolitan basis.

2/ Overall exposures resulting from operations with a single beneficiary exceeding 10 percent of the bank's own funds, as defined by the instruction 2000-07 issued by the Commission Bancaire.

3/ All credit institutions aggregated data on a parent basis company.

4/ Consolidated data for the eight main banking groups.

$5 /$ Or in other markets that are most relevant to bank liquidity, such as domestic foreign exchange markets.

6/ Impact of creation of euro has to be taken into account. 
Table 4. Life Insurance: Financial Soundness Indicators, 1998-2002 (In percent unless specified otherwise)

\begin{tabular}{|c|c|c|c|c|c|}
\hline & 1998 & 1999 & 2000 & 2001 & 2002 \\
\hline \multicolumn{6}{|l|}{ Capital adequacy } \\
\hline Net premium/capital & 279.5 & 293.2 & 314.3 & 275.0 & 265.3 \\
\hline Capital/total assets & 4.1 & 3.9 & 4.0 & 4.0 & 4.0 \\
\hline Capital (excluding unrealized gains)/technical reserves & 4.5 & 4.3 & 4.4 & 4.4 & 4.5 \\
\hline Capital (including unrealized gains)/technical reserves & 17.1 & 13.2 & 12.1 & 9.9 & 9.3 \\
\hline \multicolumn{6}{|l|}{ Asset quality } \\
\hline (Real estate + unquoted equities + receivables)/total assets & 7.0 & 6.5 & 5.8 & 5.5 & 5.3 \\
\hline Receivables/(gross premium+reinsurance recoveries) & 22.6 & 16.0 & 14.9 & 16.1 & 14.4 \\
\hline Equities/total assets & 9.3 & 9.2 & 10.0 & 10.1 & 10.3 \\
\hline Noncollateralized loans/total gross loans $1 /$ & 20.2 & 15.5 & 27.3 & 36.2 & 36.3 \\
\hline \multicolumn{6}{|l|}{ Reinsurance } \\
\hline Risk retention ratio (net premium/gross premium) & 99.6 & 99.6 & 99.5 & 99.5 & 99.3 \\
\hline Net technical reserves/average net payout & $1,549.5$ & $1,578.3$ & $1,530.6$ & $1,475.6$ & $1,397.2$ \\
\hline Net technical reserves/average net premiums & 712.0 & 793.6 & 833.5 & 815.9 & 813.7 \\
\hline \multicolumn{6}{|l|}{ Management soundness } \\
\hline Gross premium per employee (in euro millions) 2/ & 1.3 & 1.4 & 1.7 & 1.6 & 1.6 \\
\hline Total assets per employee (in euro millions) $2 /$ & 11.3 & 11.8 & 13.9 & 14.0 & 14.7 \\
\hline \multicolumn{6}{|l|}{ Earning and profitability } \\
\hline Loss ratio (net claims/net premium) & 58.5 & 55.6 & 51.6 & 59.8 & 64.2 \\
\hline Expense ratio (expenses/net premium) & 8.6 & 8.1 & 7.6 & 8.4 & 8.5 \\
\hline Combined ratio (loss ratio + expense ratio) & 67.2 & 63.7 & 59.3 & 68.2 & 72.8 \\
\hline Investment income/net premium & 54.4 & 63.1 & 35.0 & 21.7 & 10.5 \\
\hline Investment income/investment assets & 6.7 & 7.9 & 4.7 & 2.6 & 1.2 \\
\hline \multicolumn{6}{|l|}{ Liquidity } \\
\hline Minimum liquidity ratio 3/ & 1.2 & 1.2 & 1.0 & 1.0 & 1.1 \\
\hline Maximum liquidity ratio 4/ & 101.7 & 102.2 & 98.5 & 95.7 & 98.2 \\
\hline
\end{tabular}

Source: CCA.

1/ Accounting for non-collateralized loans (i.e., excluding policy advances and mortgage loans) rather than past due loans.

2/ Employment data tend to be underestimated as employees can have a contract with a different entity (i.e., independent agents or brokers).

3/ Current minimum liabilities/liquid assets.

4/ Current maximum liabilities/liquid assets. Maximum liquid liabilities assume that every repurchasable contract is repurchased (with an approximate average annual rate of 3 percent). 
Table 5. Non-Life Insurance: Financial Soundness Indicators, 1998-2002

(In percent unless specified otherwise)

\begin{tabular}{|c|c|c|c|c|c|}
\hline & 1998 & 1999 & 2000 & 2001 & 2002 \\
\hline \multicolumn{6}{|l|}{ Capital adequacy } \\
\hline Net premium/capital & 162.7 & 165.1 & 152.9 & 151.7 & 161.1 \\
\hline Capital/total assets & 18.6 & 16.4 & 18.1 & 18.1 & 17.8 \\
\hline Capital (excluding unrealized gains)/technical reserves & 28.3 & 24.4 & 27.7 & 27.8 & 26.9 \\
\hline Capital (including unrealized gains)/technical reserves & 52.0 & 48.0 & 52.5 & 43.7 & 38.7 \\
\hline \multicolumn{6}{|l|}{ Asset quality } \\
\hline (Real estate+unquoted equities+receivables) / total assets & 24.9 & 23.2 & 24.1 & 23.6 & 20.4 \\
\hline Receivables/(gross premium+reinsurance recoveries) & 21.8 & 20.9 & 23.8 & 26.7 & 25.8 \\
\hline Equities/total assets & 23.1 & 22.3 & 23.2 & 21.9 & 20.9 \\
\hline Noncollateralized loans/total gross loans $1 /$ & 38.0 & 25.2 & 57.4 & 67.7 & 57.9 \\
\hline \multicolumn{6}{|l|}{ Reinsurance } \\
\hline Risk retention ratio (net premium / gross premium) & 83.7 & 83.3 & 82.2 & 80.6 & 79.8 \\
\hline Net technical reserves/average net paid & 247.3 & 265.4 & 256.8 & 258.9 & 261.6 \\
\hline Net technical reserves/average net premiums & 181.8 & 195.3 & 195.3 & 197.2 & 197.6 \\
\hline \multicolumn{6}{|l|}{ Management soundness } \\
\hline Gross premium per employee (in euro thousands) 2/ & 429.5 & 440.5 & 468.2 & 477.3 & 538.7 \\
\hline Total assets per employee (in euro millions) $2 /$ & 1.2 & 1.4 & 1.4 & 1.4 & 1.5 \\
\hline \multicolumn{6}{|l|}{ Earning and profitability } \\
\hline Loss ratio (net claims / net premium) & 81.8 & 88.1 & 84.7 & 81.1 & 79.6 \\
\hline Expense ratio (expenses/net premium) & 25.4 & 25.4 & 25.7 & 25.6 & 24.8 \\
\hline Combined ratio (loss ratio + expense ratio) & 107.1 & 113.5 & 110.4 & 106.8 & 104.4 \\
\hline Investment income/net premium & 14.7 & 20.1 & 19.8 & 15.4 & 8.9 \\
\hline Investment income/investment assets & 6.0 & 7.8 & 7.7 & 6.1 & 3.7 \\
\hline Revisions to technical reserves/technical reserves $3 /$ & -0.3 & -2.2 & 2.6 & -1.6 & -1.8 \\
\hline ROE (return on equity) & 1.9 & 3.8 & 9.7 & 8.6 & 3.4 \\
\hline
\end{tabular}

Source: CCA.

1/ Accounting for non-collateralized loans (i.e., excluding policy advances and mortgage loans) rather than past due loans.

2/ Employment data tend to be underestimated as employees can have a contract with a different entity (i.e., independent agents or brokers).

3/ Negative numbers occur when technical reserves are revised downward. The positive number in 2000 is a consequence of the major storms in 1999, the effects of which were underestimated in the end-1999 accounts. 
Table 6a. Banking Sector Stress Testing Results

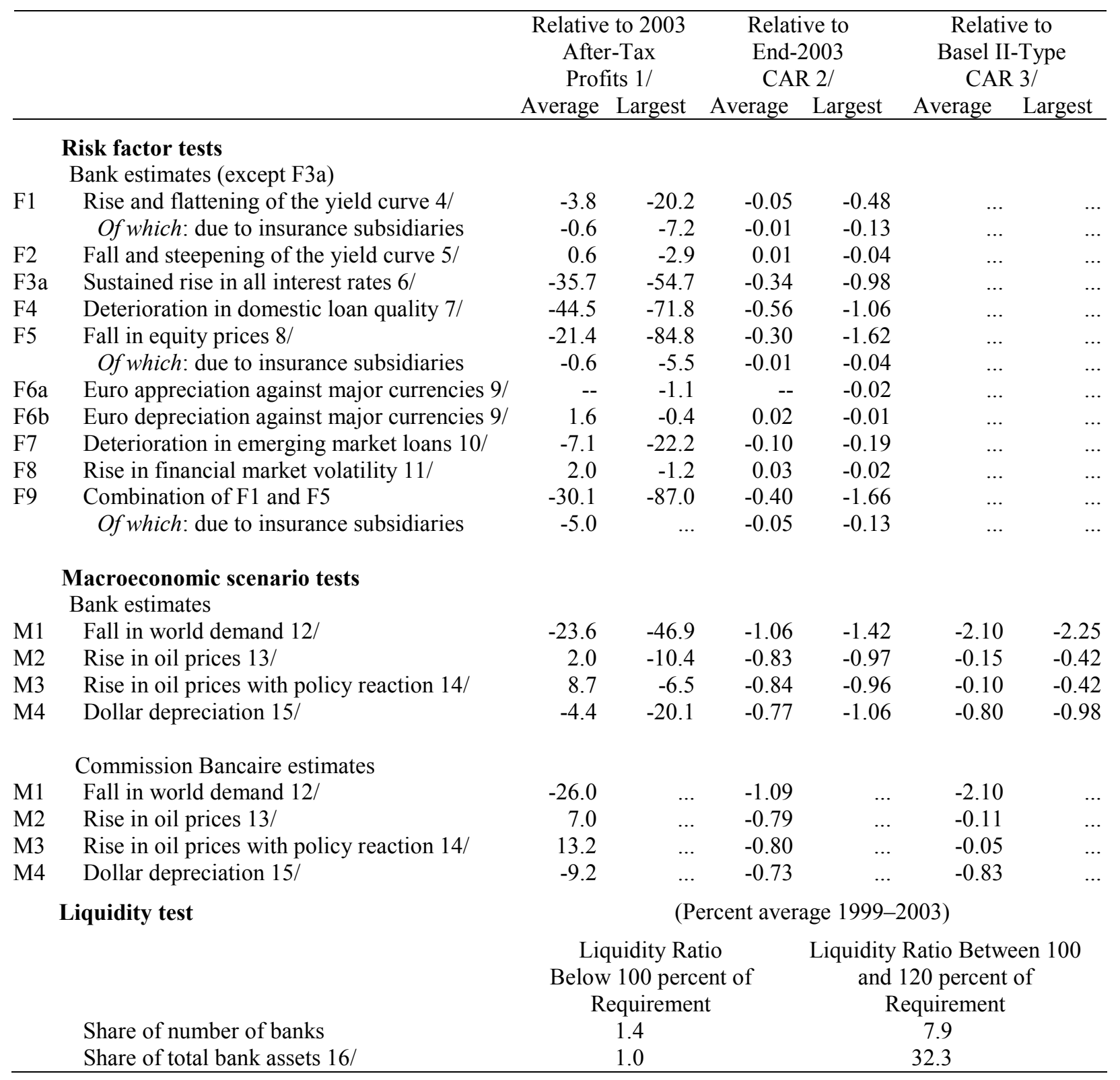

Source: French authorities, and staff estimates.

1/ After-tax impact as percent of 2003 after-tax profits.

2/ Before tax impact relative to end-2003 risk-weighted capital adequacy ratio, in percentage points.

3/ Impact on risk-weighted capital adequacy ratio, allowing for accumulated after-tax profits, credit growth, and change in risk weights, in percentage points.

4/ Overnight rates rise by 150 basis points, 10-year bond yields rise by 50 basis points, and intermediate rates rise by interpolated amounts.

5/ Overnight rates fall by 50 basis points, 10-year bond yields are unchanged, and intermediate rates fall by interpolated amounts. 
6/ A sustained increase in all interest rates by 300 basis points; the effects on insurance companies are estimated by the CCA, and the effects on parent banks by the CB. The direct effect on banks of the interest rate rise is not estimated.

7/ Loans to vulnerable sectors (energy, commercial real estate, telecoms, and transportation) by two ratings notches, and a deterioration of the quality of all other loans by one ratings notch.

8/ French, other European, U.S. and Japanese equity prices all fall 30 percent.

9/ A 15 percentage appreciation or depreciation in the euro against the U.S. dollar and Japanese yen, respectively.

10/ A two-notch downgrade of claims on emerging markets countries that comprise at least 50 percent of banks' total exposure to emerging market, and a one notch deterioration applied to all others.

11/ A 30 percent increase in the volatility of all financial market prices.

12/ A decline in world demand for French products by 20 percent.

$13 /$ An increase in petroleum prices by about 50 percent.

$14 /$ An increase in petroleum prices by about 50 percent, with a policy reaction by the ECB to dampen the inflationary effect.

15/ A sustained depreciation of the U.S. dollar against other major currency of 32 percent.

16/ Excluding in one period the effect of one merger, which for technical reasons temporally depressed the liquidity ratios of the banks concerned below 100 percent. 


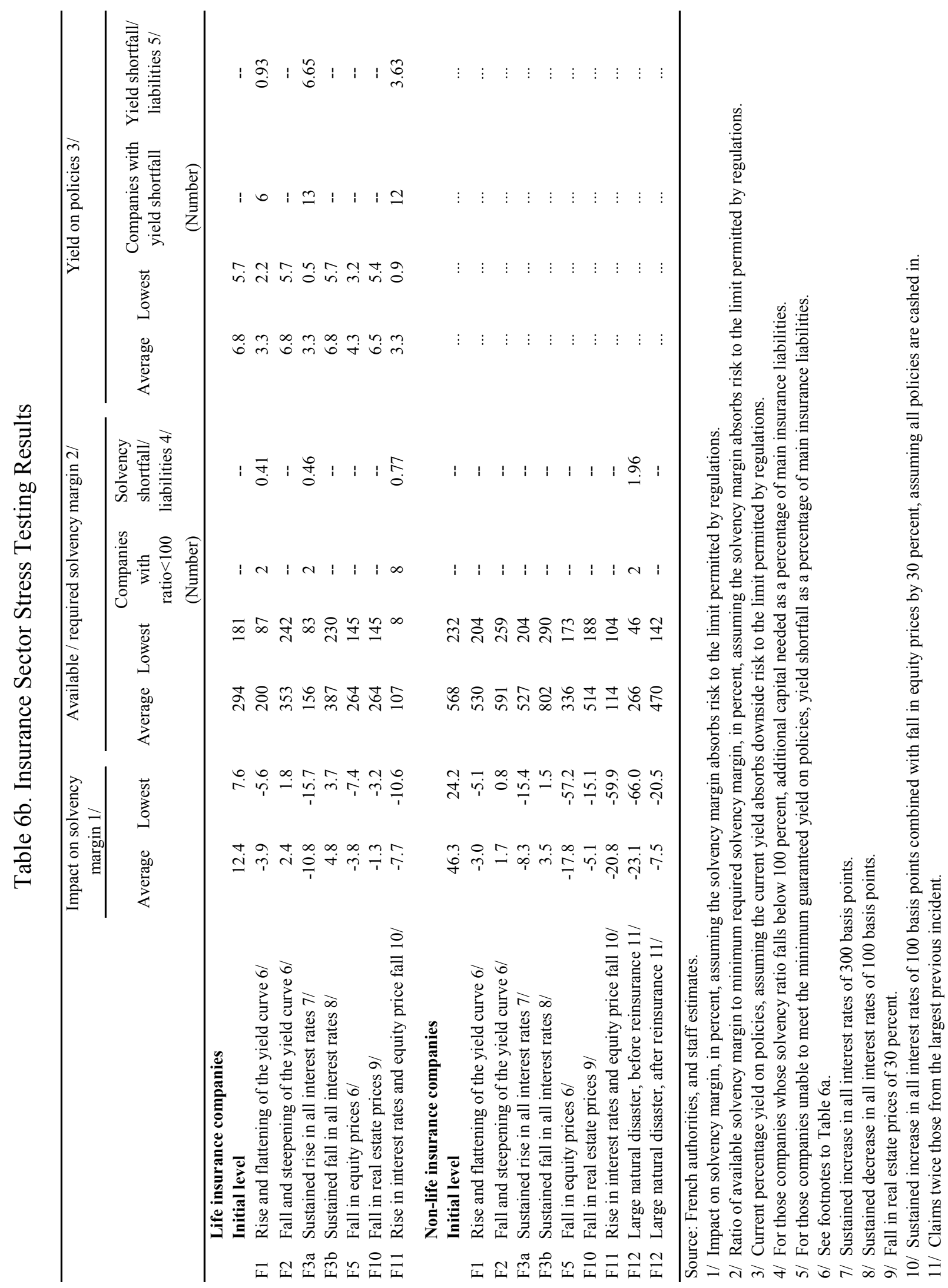

